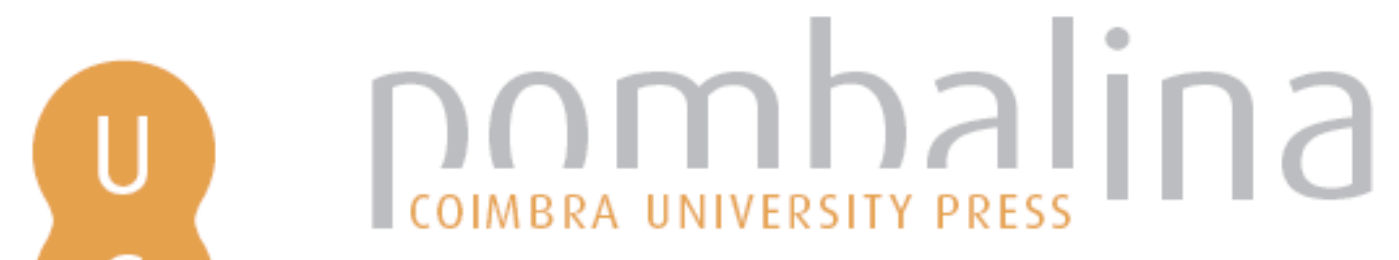

\title{
Formação de nomes
}

Autor(es): $\quad$ Rio-Torto, Graça; Rodrigues, Alexandra Soares

Publicado por: Imprensa da Universidade de Coimbra

URL

persistente: URI:http://hdl.handle.net/10316.2/38914

DOI: $\quad$ DOI:http://dx.doi.org/10.14195/978-989-26-0864-8_2

Accessed : $\quad$ 26-Apr-2023 14:51:17

A navegação consulta e descarregamento dos títulos inseridos nas Bibliotecas Digitais UC Digitalis, UC Pombalina e UC Impactum, pressupõem a aceitação plena e sem reservas dos Termos e Condições de Uso destas Bibliotecas Digitais, disponíveis em https://digitalis.uc.pt/pt-pt/termos.

Conforme exposto nos referidos Termos e Condições de Uso, o descarregamento de títulos de acesso restrito requer uma licença válida de autorização devendo o utilizador aceder ao(s) documento(s) a partir de um endereço de IP da instituição detentora da supramencionada licença.

Ao utilizador é apenas permitido o descarregamento para uso pessoal, pelo que o emprego do(s) título(s) descarregado(s) para outro fim, designadamente comercial, carece de autorização do respetivo autor ou editor da obra.

Na medida em que todas as obras da UC Digitalis se encontram protegidas pelo Código do Direito de Autor e Direitos Conexos e demais legislação aplicável, toda a cópia, parcial ou total, deste documento, nos casos em que é legalmente admitida, deverá conter ou fazer-se acompanhar por este aviso. 


\section{GRAMÁTICA \\ DERIVACIONAL \\ DO PORTUGUÊS}

GRAÇA RIO-TORTO

ALEXANDRA SOARES RODRIGUES

ISABEL PEREIRA

RUI PEREIRA

SÍLVIA RIBEIRO

2. ${ }^{a}$ EDIÇÃO

IMPRENSA DA UNIVERSIDADE DE COIMBRA COIMBRA UNIVERSITY PRESS 


\section{CAPÍTULO 2 FORMAÇÃO DE NOMES}

Graça Rio-Torto

Alexandra Soares Rodrigues ${ }^{14}$

Neste capítulo analisa-se a formação de nomes em português, descrevendo-se os nomes formados a partir de bases adjetivais (cf. 2.1), nominais (cf. 2.2) e verbais (cf. 2.4.). Para a análise de cada produto tem-se em conta (i) a categoria lexical da base, (ii) a significação genérica obtida, (iii) o processo e (iv) o afixo gerador, quando existe.

Os nomes derivados do português podem ter por base adjetivos (ruim > ruindade) (secção 2.1), nomes (livro > livraria; pata > patada) (secção 2.2) e verbos (solidificar > solidificação) (secção 2.4). Neste capítulo não nos dedicaremos ao estudo dos avaliativos (casa > casota), que serão analisados em capítulo próprio (cap. 5), nem ao estudo de nomes prefixados gerados com base em nomes, como amor > desamor, que são descritos no cap. 7, dedicado à prefixação. Três secções específicas deste capítulo são consagradas à formação de nomes por conversão de radicais (cf. 2.3., 2.4.3.1) e de palavras (2.4.3.2).

Os nomes derivados podem apresentar significações que se situam em níveis mais abstratos ou mais concretos. Esta variação

14 Alexandra Soares Rodrigues é autora da secção 2.4 Nomes deverbais. O demais texto é da autoria de Graça Rio-Torto. 
resulta, em primeiro lugar, do tipo de base a partir do qual se forma o produto, do tipo de afixo, do processo e da regra de formação envolvidos. Porque no âmbito de uma mesma regra há processos mais e menos polissémicos, procuraremos em cada secção mostrar quais as significações que podem surgir em cada tipo de produto.

\subsection{Nomes deadjetivais}

Os nomes deadjetivais sufixados construídos com base em radicais adjetivais são conhecidos por nomes de "qualidade" ou nomes de "propriedade", porque denotam propriedades, qualidades ou caraterísticas expressas pela base adjetival (a dureza/salinidade da água) e/ou o estado caraterizado por essa propriedade (a gravidez da Sofia). Por metonímia, alguns destes nomes denotam atitudes (as loucuras, as tontices que o João fez!) e entidades (eram raras as beldades/personalidades presentes no evento; os francesismos deste texto; toda a realeza assistiu à jubilação) caraterizadas por tais propriedades.

Nesta secção excluem-se nomes construídos por derivação em latim, como confusão, conexão, extensão, exaustão, perfídia. Embora relacionáveis com as bases confus-, extens-, exaust-, perfid-, não se trata de palavras construídas da língua portuguesa, mas de unidades lexicais por esta importadas.

No quadro seguinte podem observar-se nomes formados por adjunção de sufixos nominalizadores a radicais adjetivais:

\begin{tabular}{|l|l|}
\hline Sufixos & Nomes \\
\hline -eir(a) & $\begin{array}{l}\text { asneira, baboseira, bandalheira, cegueira, doideira, magreira, snobeira, } \\
\text { sujeira, tonteira }\end{array}$ \\
\hline -ez & $\begin{array}{l}\text { altivez, aridez, avidez, estupidez, fluidez, gaguez, invalidez, pacatez, } \\
\text { pequenez, rapidez, robustez, solidez, sordidez, surdez, tacanbez, timidez, } \\
\text { vetustez }\end{array}$ \\
\hline
\end{tabular}




\begin{tabular}{|l|l|}
\hline$-\boldsymbol{e z}(\boldsymbol{a})$ & $\begin{array}{l}\text { avareza, braveza, crueza, delicadeza, destreza, dureza, esbelteza, esperteza, } \\
\text { estreiteza, firmeza, franqueza, grandeza, justeza, largueza, leveza, } \\
\text { ligeireza, miudeza, pobreza, pureza, riqueza, rudeza, singeleza, subtileza, } \\
\text { tristeza, vagueza }\end{array}$ \\
\hline$-\boldsymbol{i}(\boldsymbol{a})$ & $\begin{array}{l}\text { acefalia, alegria, anomalia, autonomia, cinefilia, cortesia, fidalguia, } \\
\text { ousadia, rebeldia, sabedoria, teimosia, valentia }\end{array}$ \\
\hline -ic(e) & $\begin{array}{l}\text { bizantinice, calaceirice, casmurrice, chinesice, chatice, doidice, gabarolice, } \\
\text { garridice, malandrice, maluquice, meiguice, parvoíce, patetice, pedantice, } \\
\text { pelintrice, pirosice, teimosice, tontice, velhice }\end{array}$ \\
\hline $\begin{array}{l}\text { agilidade, amenidade, combatividade, comicidade, espiritualidade, } \\
\text { estabilidade, falsidade, fatalidade, frontalidade, interioridade, } \\
\text { modernidade, oleosidade, perenidade, pluralidade, ruralidade, senilidade, } \\
\text { serenidade, simplicidade, suavidade, subjectividade }\end{array}$ \\
\hline -ism(o) & $\begin{array}{l}\text { aptidão, certidão, devassidão, escravidão, exactidão, gratidão, lentidão, } \\
\text { mansidão, obscuridão, prontidão, rouquidão, sofreguidão, vastidão }\end{array}$ \\
$\begin{array}{l}\text { brilhantismo, casticismo, centralismo, cultismo, fatalismo, infantilismo, } \\
\text { gradualismo, heroísmo, ignorantismo, mecanicismo, pluralismo, } \\
\text { provincianismo, realismo, relativismo, rotativismo, ruralismo, sedentarismo, } \\
\text { simplismo, vedetismo, voluntarismo }\end{array}$ \\
\hline -ur(a) & $\begin{array}{l}\text { brancura, bravura, desenvoltura, doçura, espessura, estreitura, frescura, } \\
\text { gostosura (PB), largura, lisura, loucura, secura, sumidura, tristura, } \\
\text { verdura }\end{array}$ \\
\hline
\end{tabular}

Quadro II.1. Sufixos formadores de nomes deadjetivais

A estes sufixos acrescem os sufixos não disponíveis -ão (precisão $\left.{ }^{15}\right),-a t(o)$ (anonimato), -íci(a) (malícia), -íci(e) (calvície, imundicie), -nci(a) (arrogância, elegância), -or (amargor, frescor, negror, torpor, verdor), -um(e) (azedume, negrume, pesadume, pretume) e -itud(e), presente em eruditismos como altitude, amplitude, beatitude, decrepitude, longitude, latitude, magnitude, negritude, plenitude, quietude, solicitude. Muitas das palavras em que ocorrem são eruditas (amplitude, arrogância, calvície, imundicie, longitude, magnitude, tolerância), tendo muito provavelmente provindo diretamente do latim para o português, pelo que não terão sido

15 Este nome significa 'rigor' (precisão de traço, de mãos; precisão na gestão de património), necessidade (cf. letra de música de Luiz Marenco 'Das precisão pra viver" "Não preciso quase nada pra vida de peão [...] Cavalo forte altaneiro, boa rédea, boa cabeça Que se lembre se eu me esqueça das precisão de campeiro"). No PE o sentido de 'necessidade', em ter precisão de cf. "O João vive em situação de precisão" é usado por falantes menos jovens. 
construídas nesta língua. Não se trata portanto de sufixos eruditos do português, mas de sufixos presentes em palavras de origem grecolatina que a língua portuguesa incorporou.

De acordo com Moita et al. (2010) ${ }^{16}$, os sufixos disponíveis distribuem-se do seguinte modo em termos de produtividade (a este conjunto falta -eira(a), ausente no estudo citado):

\begin{tabular}{|llll|}
\hline 1.-idade $(52,5 \%)$ & 3.-ismo $(7,7 \%)$ & 5.-ez $(4,3 \%)$ & 7.-idão $(2,4 \%)$ \\
2.-ia $(21 \%)$ & 4.-ice $(6,4 \%)$ & 6.-eza $(3,6 \%)$ & 8.-ura $(2,2, \%)$ \\
\hline
\end{tabular}

Os sufixos -idad(e), -ism(o) $e-i(a)$ são os mais internacionais, no sentido de translinguísticos. Os sufixos -ic(e), -ez, -ez(a) são autóctones, nomeadamente da língua portuguesa, tendo origem no latino -ITIYA-.

Na secção seguinte caraterizam-se as bases quanto à sua estrutura morfológica e quanto às propriedades combinatórias com os sufixos mais representativos deste domínio de formação de palavras. Descrevem-se, depois, os aspectos fundamentais da semântica dos nomes deadjetivais em causa, na sua correlação com as bases e os sufixos.

\subsubsection{Bases e sufixos}

As bases dos nomes em apreço são sempre radicais e podem ser morfologicamente simples (alegr-: alegria) ou complexas. Enquanto complexas, podem ser sufixadas (angolan-: angolanidade; brasileir-: brasileirismo; tropical: tropicalismo) ou compostas (caboverdian-: caboverdianidade; cenograf-: cenografia; chico-esperto: chico-espertismo; tardo-medieval: tardo-medievalismo):

16 Para uma panorâmica sobre a formação de nomes de qualidade ver Correia (2004). 


\begin{tabular}{|c|c|c|}
\hline \begin{tabular}{|l|} 
Sufixos \\
\end{tabular} & N com bases simples & N com bases complexas \\
\hline$-\operatorname{eir}(a)$ & $\begin{array}{l}\text { asneira, cegueira, doideira, } \\
\text { magreira, snobeira, sujeira, tonteira }\end{array}$ & baboseira, bandalheira, caturreira \\
\hline$-e z$ & $\begin{array}{l}\text { aridez, avidez, estupidez, gaguez, } \\
\text { pacatez, pequenez, rapidez, robustez, } \\
\text { solidez, surdez, timidez, vetustez }\end{array}$ & $\begin{array}{l}\text { altivez, honradez, limpidez, } \\
\text { malcriadez, sisudez, tartamudez }\end{array}$ \\
\hline$-e z(a)$ & $\begin{array}{l}\text { avareza, braveza, crueza, destreza, } \\
\text { dureza, esbelteza, esperteza, } \\
\text { estreiteza, firmeza, franqueza, } \\
\text { grandeza, justeza, largueza, leveza, } \\
\text { mindeza, pobreza, pureza, riqueza, } \\
\text { rudeza, tristeza, vagueza }\end{array}$ & $\begin{array}{l}\text { descaradeza, emproadeza, safadeza, } \\
\text { sisudeza }\end{array}$ \\
\hline$-i(a)$ & alegria, rebeldia & $\begin{array}{l}\text { acefalia, autonomia, burguesia, } \\
\text { cardiologia, cinefilia, cortesia, } \\
\text { farmacologia, fidalguia, malfeitoria, } \\
\text { ousadia, sabedoria, teimosia, valentia }\end{array}$ \\
\hline$-i c(e)$ & $\begin{array}{l}\text { chatice, doidice, malandrice, } \\
\text { maluquice, meiguice, parvoíce, } \\
\text { pelintrice, tontice, velhice }\end{array}$ & $\begin{array}{l}\text { alcoviteirice, bizantinice, caloteirice, } \\
\text { chinesice, curandeirice, fanfarronice, } \\
\text { gabarolice, pedinchice, parvo- } \\
\text { alegrice, sem-vergonbice, teimosice }\end{array}$ \\
\hline$-i d a d(e)$ & $\begin{array}{l}\text { agilidade, amenidade, falsidade, } \\
\text { interioridade, serenidade, } \\
\text { simplicidade, suavidade }\end{array}$ & $\begin{array}{l}\text { caboverdianidade, combatividade, } \\
\text { espiritualidade, familiaridade, } \\
\text { frontalidade, maleabilidade }{ }^{17}, \\
\text { oleosidade, preciosidade, subjectividade }\end{array}$ \\
\hline -idão & $\begin{array}{l}\text { amarelidão, aptidão, certidão, } \\
\text { escravidão, escuridão, gratidão, } \\
\text { lentidão, mansidão, prontidão, } \\
\text { rouquidão, vastidão }\end{array}$ & sofreguidão \\
\hline$-i s m(o)$ & $\begin{array}{l}\text { cultismo, fatalismo, heroísmo, } \\
\text { pessimismo, simplismo, snobismo, } \\
\text { vedetismo }\end{array}$ & $\begin{array}{l}\text { afrotropicalismo, brilhantismo, } \\
\text { casticismo, centralismo, } \\
\text { chico-espertismo, classicismo, } \\
\text { ignorantismo, materialismo, } \\
\text { parlamentarismo, parvo-alegrismo, } \\
\text { porreirismo, provincianismo, } \\
\text { rotativismo, sedentarismo, } \\
\text { termalismo, voluntarismo }\end{array}$ \\
\hline$-\operatorname{ur}(a)$ & $\begin{array}{l}\text { brancura, bravura, doçura, } \\
\text { espessura, estreitura, frescura, } \\
\text { largura, lisura, loucura, secura, } \\
\text { tristura, verdura }\end{array}$ & compostura, formosura \\
\hline
\end{tabular}

Quadro II.2. Radicais adjetivais simples e complexos selecionados pelos sufixos nominalizadores

O facto de um mesmo sufixo poder selecionar bases simples ou complexas mostra que não há combinatórias impositivas e obriga-

17 O sufixo -vel da base sofre alomorfia, reconfigurando-se em -bil-, na presença doutro sufixo. 
tórias entre os sufixos mencionados e uma estrutura morfológica específica da base. Há, contudo, casos de uma maior preferência por um ou outro tipo de base, como se pode constatar a seguir.

Com efeito, o quadro anterior permite observar que:

(i) os sufixos -idão e -ur(a) agregam-se quase exclusivamente a bases simples;

(ii) -ez e -ez(a) selecionam dominantemente bases simples ${ }^{18}$;

(iii) os sufixos -i(a), -ic(e), -idad(e) e -ism(o) selecionam dominantemente bases complexas.

Dos sufixos que se combinam com bases complexas, -i(a) é o que mais tendência revela para selecionar compostos morfológicos de cunho erudito, terminados por exemplo em $-\operatorname{crat}(o / a)$, $-\operatorname{crom}(o / a),-g o g(o / a),-g r a f(o / a),-\log (o / a)$ que, uma vez nominalizados, apresentam a configuração -cracia (aristocracia, autocracia, cleptocracia, democracia, tecnocracia), -cromia (policromia), -gogia (demagogia, pedagogia), -grafia (geografia, tipografia), -logia (astrologia, lexicologia). Alguns destes nomes denotam atividades e/ou disciplinas científicas (pedagogia, agronomia), mas também doenças (acefalia). Mas este sufixo também se combina com bases sufixadas, nomeadamente que denotam comportamento e atitudes (idolatria, mediania, ousadia, rebeldia, teimosia, valentia).

No conjunto dos nomes deadjetivais, -ic(e), -idad(e) e -ism(o) são sufixos que se combinam facilmente com adjetivos denominais. O Quadro II.3 apresenta exemplos dessa realidade, evidenciando a compatibilidade entre os sufixos das bases adjetivais (coluna da esquerda) e os sufixos nominalizadores.

${ }^{18}$ Até ao século XVII -ez e -eza funcionaram em variação mais livre. A partir de então, -ez tende a ocorrer em nomes cuja base tem três ou mais sílabas, como altivez, estupidez, fluidez, robustez, sisudez (ainda que com excepções, como gaguez, surdez); -eza tende a combinar-se com bases de duas ou mais sílabas (braveza, dureza, firmeza, grandeza). 


\begin{tabular}{|c|c|c|c|}
\hline $\begin{array}{l}\text { Sufixos } \\
\text { adjetivalizadores } \\
\text { das bases }\end{array}$ & $\begin{array}{l}\text { Derivados em } \\
\text {-ic(e) }\end{array}$ & $\begin{array}{l}\text { Derivados em } \\
\text {-idad(e) }\end{array}$ & $\begin{array}{l}\text { Derivados em } \\
\text {-ism(o) }\end{array}$ \\
\hline$-a l$ & sensacionalice & $\begin{array}{l}\text { materialidade } \\
\text { superficialidade }\end{array}$ & sensacionalismo, triunfalismo \\
\hline$-a n-$ & $\begin{array}{l}\text { americanice } \\
\text { mundanice }\end{array}$ & $\begin{array}{l}\text { mundanidade } \\
\text { urbanidade }\end{array}$ & cartesianismo, provincianismo \\
\hline$-a r$ & parlamentarice & familiaridade & parlamentarismo \\
\hline -eir- & $\begin{array}{l}\text { caloteirice } \\
\text { faceirice }\end{array}$ & femeeiridade & $\begin{array}{l}\text { bandoleirismo } \\
\text { caloteirismo }\end{array}$ \\
\hline -êes & $\begin{array}{l}\text { francesice } \\
\text { burguesice }\end{array}$ & portuguesidade & $\begin{array}{l}\text { francesismo } \\
\text { burguesismo }\end{array}$ \\
\hline -ic- & $\begin{array}{l}\text { pinderiquice } \\
\text { sumoliquices }^{19}\end{array}$ & $\begin{array}{l}\text { dramaticidade } \\
\text { bistoricidade } \\
\text { periodicidade }\end{array}$ & $\begin{array}{l}\text { academicismo } \\
\text { biblicismo } \\
\text { bistoricismo }\end{array}$ \\
\hline$-(t) i v-$ & negativice & $\begin{array}{l}\text { combatividade } \\
\text { impulsividade }\end{array}$ & combativismo comparativismo \\
\hline -os- & $\begin{array}{l}\text { mentirosice } \\
\text { teimosice }\end{array}$ & $\begin{array}{l}\text { animosidade } \\
\text { perigosidade }\end{array}$ & $\begin{array}{l}\text { rigorosismo } \\
\text { nervosismo }\end{array}$ \\
\hline$-b i l-$ & -- & $\begin{array}{l}\text { amabilidade } \\
\text { razoabilidade }\end{array}$ & $\begin{array}{l}\text { miserabilismo } \\
\text { notabilismo }\end{array}$ \\
\hline
\end{tabular}

Quadro II.3. Sufixos -ic(e), -idad(e) e -ism(o) e tipo morfológico de bases que selecionam

Neste quadro, o espaço não preenchido significa ausência de dados, como no caso de derivados em -bilice. Em teoria, nenhuma das possibilidades combinatórias está vedada à língua portuguesa, mas a verdade é que -idad(e) e -ism(o) são, dos três sufixos, os mais usados e os claramente mais flexíveis sob o ponto de vista combinatório. A grande versatilidade combinatória destes dois sufixos, quer em relação à natureza simples ou complexa das bases, quer em relação à semântica destas, explica a significativa produtividade e disponibilidade destes operadores.

\subsubsection{Semântica dos nomes deadjetivais formados por sufixação}

Descrevem-se nesta secção as relações semânticas desencadeadas pela combinatória dos sufixos mais representativos na formação de

19 Nome formado com base no radical de sumólico, adjetivo neológico do PE para denotar os amantes da bebida denominada Sumol. Em vez da combinatória em -icice, a língua opta por manter o som [k] do radical em -ic-, em casos como caloriquices, catoliquices, pandoriquices. 
nomes deadjetivais, como -idad(e), -i(a), -ic(e), -ism(o), e também dos menos produtivos. Essas relações têm em conta a semântica das bases e as propriedades específicas de cada sufixo.

Os nomes deadjetivais que denotam propriedades ou estados funcionam tipicamente como nomes abstratos. Quando assim é, os nomes ocorrem normalmente no singular e não admitem pluralização ou quantificação (cf. Rio-Torto \& Anastácio 2004): avareza, dureza, cegueira, honradez ou sedentarismo, que denotam propriedades, não são pluralizáveis ou quantificáveis (cf. *quatro cegueiras, *duas avarezas, *as honradezes, *muitos sedentarismos), inscrevendo-se portanto na classe dos nomes massivos ou [-contável].

Quando denotam atitudes próprias ou caraterísticas de quem apresenta a propriedade adjetival de base, podem encontrar-se na forma pluralizada (cf. as pirosices/piroseiras que vocês dizem!; o avô ficou sensibilizado com as amabilidades/cortesias da neta; a população está supreendida com os radicalismos dos manifestantes), admitindo por vezes também quantificação (cf. o médico deu duas alegrias ao doente: benignidade do tumor e dispensa de cirurgia; ele cometeu várias infantilidades), pelo que deixam de ser analisados como nomes massivos e adquirem o traço [+contável].

\subsubsection{Nomes sufixados em -idad(e)}

O sufixo -idad(e) ${ }^{20}$ combina-se com bases adjetivais de estrutura simples, mas também com bases morfológica e semanticamente complexas. Nestas destacam-se as derivadas denominais (cf. angularidade, atomicidade, causalidade, cristalinidade, esponjosidade, familiaridade, festividade, fiscalidade, heroicidade, masculinidade,

20 Combinado com algumas bases, o sufixo tem a configuração-dad- (beldade, crueldade, lealdade, maldade) que, sendo menos representada, não é a mais prototípica. 
normalidade, ociosidade, opalinidade, perigosidade, porosidade, secularidade, vulcanicidade) e as deverbais (combativo/combatividade, dilatável/dilatabilidade, traficável/traficabilidade, variável/ variabilidade), como se ilustra no quadro seguinte. A sequência -eiridade não é muito comum.

\begin{tabular}{|l|l|}
\hline Sufixo da base & Nomes deadjetivais cujas bases são denominais ou deverbais \\
\hline -al & causalidade, fiscalidade, normalidade \\
\hline -ar & angularidade, familiaridade, secularidade \\
\hline -ic- & atomicidade, heroicidade, vulcanicidade \\
\hline -in- & cristalinidade, masculinidade, opalinidade \\
\hline -iv- & combatividade, festividade \\
\hline -os- & esponjosidade, ociosidade, perigosidade, porosidade \\
\hline -bil-21 & dilatabilidade, variabilidade \\
\hline
\end{tabular}

Quadro II.4. Sufixos presentes nas bases selecionadas por -idad(e)

O sufixo -idad(e) não é portador de traços semânticos específicos como -ism(o) (cf. 2.1.2.3), nem marca desfavoravelmente o nome, como acontece com -ic(e) (cf. 2.1.2.2). É portanto um sufixo semanticamente neutro face aos dois mencionados.

As bases preferenciais deste sufixo não são obrigatória nem especialmente marcadas sob o ponto de vista axiológico, no sentido positivo ou negativo. Algumas (disponível, permeável) admitem uma marca favorável ou desfavorável, consoante o ponto de vista e os valores do falante. Alguns radicais de base são portadores de sentidos técnicos, como por exemplo combinatorialidade, inflamabilidade, opalinidade, vulcanicidade.

O contraste entre derivados portadores de -ism(o) e de -idad(e) que têm em comum uma mesma base (por exemplo exclusivismo 'maneira de ser exclusivista; intolerância' e exclusividade 'qualidade do que é exclusivo', em regime/contrato de exclusividade) evidencia o traço de 'sistematicidade e/ou de excesso' associado a -ism(o), face ao caráter mais neutro do nome sufixado em -idad(e).

21 -bil- é a aloforma de -vel quando este se encontra na base derivante de um produto. 


\subsubsection{Nomes sufixados em $-i c(e)$}

O sufixo -ic(e) forma nomes que denotam atitudes (cf. alcoviteirice, charlatanice, criancice, mariquice, pacovice, pieguice, pandoriquices), modos de ser/estar (cf. calaceirice, matreirice), estados (cf. furibundice, meninice, velbice).

Quando a base destes nomes é o radical de um adjetivo étnico ou gentílico, que significa 'natural, originário, procedente, habitante de', o derivado em -ice denota atitudes, modos de ser/estar ou produtos provenientes ou representativos de um dado lugar, ou universo cultural/civilizacional, codificado pela base (cf. americanice $(s)$, brasileirice(s), francesice (s), espanbolice(s), portuguesice $(s))$. As bases dos adjetivos são, por sua vez, formadas a partir de bases nominais toponímicas.

A muitos dos nomes sufixados em -ic(e) está associada uma marca negativa ou desfavorável, em alguns casos também presente na base, como por exemplo em alcoviteirice, calaceirice, charlatanice, curandeirice, foleirice, javardice, parvo-alegrice, pirosice, teimosice. Já quando as bases adjetivais denotam 'originário ou natural de', como acontece com os radicais de americano, brasileiro, chinês, espanhol, francês ou português, elas não são forçosamente marcadas nem positiva nem negativamente; todavia, os derivados em -ic(e) (americanice, chinesice) são-no, denotando propriedades estereotípicas vistas como negativas associadas a uma dada cultura. O mesmo ocorre com bases não negativas, como bizantino, parlamentar, sensacional, pois os derivados bizantinice, parlamentarice, sensacionalice são marcados negativamente. Assim sendo, e por contraste com a semântica dos outros sufixos em análise, o sufixo -ic(e) veicula muitas vezes, ainda que não sistematicamente, uma significação desfavorável ou negativa, que se reflete na semântica do nome em que ocorre. Este seu valor explica a sua utilização em situações marcadas pela expressividade depreciativa. 
Como se descreve em 2.4.1.11, -ic(e) combina-se também com bases verbais (aldrabice, bajulice, bisbilhotice, chafurdice, coscuvilhice, palrice, rabujice, rapinice, resmunguice), e os nomes apresentam idêntico valor depreciativo.

\subsubsection{Nomes sufixados em -ism(o)}

O sufixo -ism(o) forma nomes de movimentos ideológicos/científicos/artísticos, de sistemas doutrinais/científicos/de mentalidades, ou ainda nomes de constructos epistemológicos relacionados com o que a base denota, como ambientalismo, espiritualismo, figurativismo, fraternalismo, fundamentalismo, gradualismo, justicialismo, luteranismo, medievalismo, republicanismo, narcisismo, mercantilismo, naturalismo, newtonianismo, partidarismo, entre muitos outros (cf. Barbosa 2012). Este sufixo agrega-se frequentemente a bases adjetivais derivadas de antropónimos, como em luteranismo e newtonianismo (luterano e Lutero, newtoniano e Newton), mas também a bases deverbais sufixadas em -dor (amadorismo, empreendedorismo), em -nt(e) (brilhantismo) e em -vel/bil (imobilismo, probabilismo, razoabilismo, vulnerabilismo).

O sufixo -ism(o) forma também nomes que denotam manifestação/praxis com caráter sistemático daquilo que a base expressa. O traço de "sistematicidade" encontra-se associado a qualidades, atitudes, ou comportamentos que assim passam a ser marcados como habituais. Se aquilo que a base denota é marcado negativa ou desfavoravelmente num dado sistema cultural, o derivado também o é, como se verifica em beijoqueirismo, caloteirismo, canibalismo, cinzentismo, contrabandismo, cretinismo, curandeirismo, decandentismo, donjuanismo, ignorantismo, obscurantismo, pato-bravismo, pieguismo, pilantrismo, primarismo, radicalismo, sectarismo, servilismo, triunfalismo, vedetismo. Quando não, o produto derivado não 
é portador de marca semântica desfavorável, como o comprovam cavalheirismo, companheirismo, desportivismo, empreendedorismo, missionarismo, naturalismo. Se, num dado universo cultural, o que a base denota pode ser negativamente encarado, então este traço perpetua-se no derivado (aventureirismo, conformismo, conservadorismo, gregarismo). Assim, e diferentemente de -ic(e), o sufixo -ism(o) não é responsável por uma leitura marcadamente desfavorável dos derivados. Mas o traço de sistematicidade, de repetitividade, de excessividade, acaba por poder contaminar alguns derivados portadores deste sufixo, como se observa em adeptismo, amiguismo, belicismo, biblicismo, economicismo, eleitoralismo, especiosismo, favoritismo, financeirismo, habitualismo, imediatismo, imobilismo, indiferentismo, infalibilismo, intuicionismo, literatismo, mediatismo, militarismo, ordeirismo, partidarismo, ritualismo, secretismo, securitismo, tolerantismo.

Os derivados em -ism(o) cujas bases remetem para um adjetivo detoponímico ou relacionado com local, denotam 'expressão própria, típica de', como arabismo, brasileirismo, dialetalismo, grecismo, italianismo, tecnicismo, regionalismo.

Este sufixo combina-se também com bases nominais (basismo, clubismo, desenvolvimentismo, divorcismo, ganancismo, ginasismo, inquilinismo, machismo, milagrismo, rigorismo, segredismo, rotulismo, sigilismo, tabaquismo, umbiguismo: cf. cap. 2: 2.2.11), com bases nominalizadas (apriorismo) e com bases verbais (bisbilhotismo, consumismo, facilitismo, rabujismo, transformismo). Os nomes assim formados têm valores idênticos aos que acabam de ser descritos.

\subsubsection{Nomes sufixados em $-i(a)$}

No conjunto dos sufixos nominalizadores deadjetivais, $-i(a)$ combina-se menos com bases simples (alegria, minoria, rebeldia) e 
mais com bases complexas, sufixadas (burguesia, cortesia, ousadia, sabedoria, teimosia) e sobretudo compostas (farmacologia). Este sufixo é o que mais seleciona compostos morfológicos de cunho erudito, terminados por exemplo em -crata, -crom-, -gog-, -graf-, -log- que, uma vez nominalizados através da adjunção de $-i(a)$, apresentam a configuração -cracia (aristocracia, autocracia, cleptocracia, democracia, tecnocracia), -cromia (policromia), -gogia (demagogia, pedagogia), -grafia (geografia, tipografia), -logia (astrologia, lexicologia).

O sufixo não é portador de um sentido específico, de cunho depreciativo, como -ic(e), ou especializado, como -ism(o), sendo portanto neutro do ponto de vista semântico, o que lhe permite funcionar como o mais apto para a formação de nomes de propriedade (anomalia, autonomia, cinefilia), de prática (cleptocracia, demagogia), de atividade (astrologia, geografia, lexicologia), de doença (acefalia, psicopatia) relacionada com o que a base denota.

Quando se combina com adjetivos de semantismo menos técnico, como alegria, os nomes podem denotar comportamento e atitudes (idolatria) e, nessa medida, ser objeto do mesmo tipo de valoração positiva (sabedoria, valentia) ou negativa (teimosia) da base, uma vez que o que esta denota também pode ser valorado favorável ou desfavoravelmente (mediania, ousadia, rebeldia).

\subsubsection{Nomes sufixados em $-\operatorname{eir}(a)$}

Um sufixo singular no conjunto dos nominalizadores deadjetivais é -eir(a); este ocorre em nomes que denotam propriedades (magreira), estados por elas caraterizadas (cegueira, sujeira) e sobretudo atitudes, como asneira, baboseira, bandalheira, caturreira, doideira, gagueira, maluqueira, maroteira, parvoeira, snobeira, tonteira.

Muitos destes nomes têm uma marca pejorativa, mas esta deve ser imputada às bases, não ao sufixo (cf. cegueira). O sufixo é usado em 
situações de familiaridade e de expressividade (caturreira, doideira), sendo diafasicamente marcado, como o ilustra o contraste com os nomes corradicais também deadjetivais, e portadores de outros sufixos, como gagueira e gaguez, magreira e magreza, snobeira e snobismo. Já sujeira se aplica a situações morais, por contraste com sujidade, apenas usada para realidades físicas. Em comparação com o nome derivado em -ic(e), tendencialmente depreciativo, o derivado em -eir (a) é portador de uma marca de expressividade mais acentuada (bandalheira, bandalhice; caturreira, caturrice; maluqueira, maluquice; maroteira, marotice; tonteira, tontice). A natureza expressiva deste sufixo permite que ele se acople, ainda que raramente, a bases nominais (cf. preguiceira), denotando intensidade (barulheira), e também a bases verbais (cf. canseira). O mesmo sentido intensivo e expressivo está presente em focinheira, pescoceira 'focinho/pescoço volumoso, desconforme'.

\subsubsection{Nomes sufixados em -idão, $-u m(e),-u r(a)$}

O sufixo -idão combina-se com bases que denominam propriedades cromáticas, como amarelidão, branquidão, negridão, pretidão, roxidão, vermelhidão; mas outras bases também são selecionadas, como se observa em aptidão, devassidão, escravidão, exactidão, gratidão, lentidão, mansidão, prontidão, rouquidão, sofreguidão, vastidão (cf. Quadro II.1.).

O sufixo -ur(a) seleciona adjetivos simples (altura, brancura, bravura, doçura, frescura, friura, lindura, lonjura, travessura, tristura) e particípios passados desflexionados (abertura, compostura, desenvoltura, fartura, polidura, soltura), muitos dos quais exprimem propriedades físicas e/ou atitudinais.

$\mathrm{O}$ contraste entre nomes corradicais em -ez(a) e em -ur(a) (como baixeza e baixura, fineza e finura, frieza e friúra, lindeza e lin- 
dura, profundeza e profundura) mostra que os nomes em -ur(a) denotam predominantemente qualidades físicas, enquanto os nomes em -ez(a) denotam predominantemente propriedades.

Escassamente abonado, o sufixo -um(e) não está também disponível no presente. Os exemplos atestados são agrume, azedume, negrume, pesadume, pretume. Ainda que raramente, este sufixo combina-se também com bases verbais, como o atestam chorume e queixume (cf. cap. 2: 2.4.1.)

\subsection{Nomes denominais}

Os nomes denominais formados por sufixação têm por base um radical nominal, autónomo ou não. Base e produto derivacional são unidades lexicais isocategoriais. Os exemplos despesismo, eleitorado, laranjal, pianista, retrosaria, tinteiro, vinhedo, derivados das bases nominais despes-, eleitor-, laranj-, pian-, retros-, tint-, vinh-ilustram esta realidade.

Como se observa nas secções seguintes, as classes semânticas dos nomes denominais (EVENTO, INDIVÍDUO, LOCAL, CAUSA/ FONTE, RESULTADO/PRODUTO) coincidem, em parte, com as que se elencam no domínio dos nomes deverbais, o que permite sublinhar a coesão interna do sistema de formação de palavras da língua portuguesa.

\subsubsection{Introdução: bases, sufixos, nomes derivados}

Ascendem a duas dezenas os sufixos que formam nomes denominais. As classes semânticas das bases e dos nomes derivados são igualmente numerosas e o grau de disponibilidade dos sufixos é também diverso. Quando são usados os sufixos -eir- e -ist(a) que 
dão origem a denominações de profissionais, estas podem variar em género (cabeleireiro/a, doceiro/a, jardineiro/a, jornaleiro/a, peixeiro/a) ou, porque uniformes, ser ambígenas/comuns de dois géneros (o/a artista, o/a jornalista). Nos demais casos (-ad(a), -ad(o), -agem, -al, -am(a), -am(e), -ari(a), -ári(o), -at(o), -ed(o), -ês, -ia, -il, -ism(o), -ist (a)), os sufixos dão origem a denominações de género fixo e independente do dos nomes a cujos radicais nominais se acoplam.

No âmbito dos sufixos de nominalização denominal há alguns que possuem um semantismo unívoco e preciso, como por exemplo os que formam denominações técnico-científicas (-at(o), -et(o), -it(o), -in(a), -it(e), -os(e)). Também assim acontece com os nomes em -ão, a maior parte dos quais de formação recente, e que denotam uniformemente "objeto contentor de x"/"objeto onde se deposita, para reciclagem, x” (pilhão, plasticão). A maior parte dos sufixos de nominalização denominal é marcada por uma significativa amplitude de significações, formando nomes de classes semânticas diversas. Por exemplo, os nomes em -eir- podem denotar árvores (pereira), objetos (bomboneira, camiseiro, chaveiro, papeleira), local onde existe grande quantidade (areeiro, marmoreira, pedreira), profissional de atividade (armeiro, cesteiro/a). Também os nomes em -ad(a) denotam conjunto (garotada), golpe (facada), evento (abrilada), preparado à base de (cebolada). Aos nomes em -ist $(a)$ estão associadas significações mais aparentadas entre si, como "especialista em $x$ " (paisagista, toxicologista), "profissional de x" (camionista, equilibrista), "actante relacionado com x" (articulista, artista, ceramista, equilibrista, jornalista), em que $\mathrm{x}$ representa o que a base denota.

As bases dos nomes denominais derivados por sufixação podem ser radicais simples ou complexos, qualquer que seja o sufixo ativado e a significação que imprime ao derivado, como se pode observar no quadro seguinte: 


\begin{tabular}{|c|c|c|}
\hline Sufixos & Bases simples & Bases complexas \\
\hline$-\operatorname{ad}(a, o)$ & $\begin{array}{l}\text { consulado, ducado, facada, } \\
\text { garotada, papelada, } \\
\text { tomatada }\end{array}$ & $\begin{array}{l}\text { arcebispado, arciprestado, carneirada, } \\
\text { catecumenado, cavaleirado, comissariado, } \\
\text { estudantada, foguetada, patronato, } \\
\text { patriarcado, peixeirada, pontificado, } \\
\text { preceptorado, provincialado, tabelionado }\end{array}$ \\
\hline -agem & folhagem & criadagem, milhagem, quilometragem \\
\hline$-a l$ & $\begin{array}{l}\text { areal, arrozal, batatal, } \\
\text { toural }\end{array}$ & penhascal, pinheiral, salitral \\
\hline$-a m(e, a)$ & cordame, mourama, velame & sardinhame, vasilhame \\
\hline$-\tilde{a} o$ & $\begin{array}{l}\text { papelão, pilhão, rolhão, } \\
\text { vidrão }\end{array}$ & eletrodomesticão, plasticão \\
\hline$-\operatorname{ari}(a)$ & doçaria, papelaria & tinturaria \\
\hline -ári(o) & preçário, reptilário & questionário \\
\hline$-a t(o)$ & baronato, colonato & canonicato, cavaleirato \\
\hline$-\operatorname{ed}(\boldsymbol{o})$ & arvoredo, vinhedo & figueiredo \\
\hline$-\operatorname{eir}(a, o)$ & fruteira, roupeiro, saleiro & azeitoneira, compoteira \\
\hline -eir- & ceifeiro/a, jardineiro/a & cabeleireiro/a \\
\hline -ês & economês, eduquês, jornalês & maternalês, mimalhês, sociologuês \\
\hline$-i(a)$ & capitania, freguesia & burguesia, fidalguia \\
\hline -il & cabril, gatil, touril & \\
\hline$-i(o)$ & mulherio, rapazio & compadrio \\
\hline$-i s m(o)$ & bombismo, darwinismo & carreirismo, clientelismo, quatrocentismo \\
\hline$-i s t(a)$ & artista, bumorista, taxista & automobilista, toxicologista \\
\hline
\end{tabular}

Quadro II.5. Sufixos formadores de nomes denominais

Os nomes denominais constituem um conjunto heterogéneo de derivados, no qual se incluem nomes coletivos e/ou locativos, nomes de agentes profissionais ou de atividade, nomes de objeto continente, de evento, entre outros. Essa heterogeneidade espelha a grande diversidade de nexos semânticos que se podem estabelecer entre as bases nominais que denotam uma vasta gama de realidades e os nomes delas derivados sufixalmente.

Em alguns casos existem notórias interferências semânticas entre classes de nomes denominais: assim acontece com os locativos que, não raro, acumulam um sentido coletivo, como se observa em coelheira, enfermaria, leprosaria, orquidário, pedreira, vacaria, por exemplo. Mas outras classes de nomes ilustram a possibilidade de congregar vários sentidos: internato denota 'escola onde os alunos têm alimentação e 
residência; situação de um aluno interno; conjunto dos internos de um colégio; tirocínio por que passam os médicos ou os estudantes de medicina, depois de formados, trabalhando em hospitais'; vicariato denota 'função ou exercício da função de vigário; tempo que dura esse exercício; território sob a jurisdição de um vigário'.

Em outros casos, a semântica dos nomes não apresenta relações com nomes denominais de outras classes, como acontece com os nomes de infeções (amigdalite, apendicite, gengivite) e doenças (furunculose, silicose), ou com os nomes de "golpe" ou de "pancada" com um objeto/instrumento ou parte do corpo (cacetada, cotovelada, facada, patada, paulada).

Três ordens de razões se conjugam para que a descrição dos nomes denominais se faça à luz das classes semânticas destes:

(i)o facto de a natureza semântica das classes nominais das bases desempenhar, em conjunção com a semântica dos sufixos, um papel determinante no sentido dos nomes sufixalmente construídos;

(ii) o facto de o semantismo dos derivados se organizar em classes léxico-conceptuais estruturantes da gramática da língua portuguesa, como sejam as de QUANTIDADE, de LOCATIVIDADE, de AGENTIVO, na sua manifestação de 'profissional de atividade', e ainda de FONTE (vegetal), de objeto CONTENTOR, de CONTEÚDO, de EVENTO, de INSTRUMENTO, etc.

(iii)a heterogeneidade de comportamento dos sufixos, nomeadamente o facto de alguns apresentarem um semantismo diverso em função da natureza semântica das bases a que se acoplam e o de outros possuírem um semantismo bem definido.

Assim, a descrição dos nomes denominais sufixalmente derivados é feita com base nas classes semânticas que eles codificam e associam-se, em cada caso, os sufixos que concorrem para a codificação de tais valores. 


\subsubsection{Nomes de quantidade}

Os nomes coletivos sufixalmente derivados denotam conjuntos plurais e homogéneos de entidades codificadas pelo radical nominal de base.

Os nomes de quantidade têm por base radicais simples e radicais complexos e podem ser formados pela adjunção de vários sufixos, tais como -ad( $(a, o),-\operatorname{ari}(a),-\operatorname{agem},-e d(o),-e t(o),-a l b(a, o),-a m(e, a),-a ́ r i(o)$, $-a t(o),-i(a),-i(o)$. Os sufixos -ad(a) e -agem são os mais produtivos. Não se referem aqui sufixos menos representados com este valor, como -eir- (cf. piolheira), pois alguns derivados em que ocorre denotam não já a quantidade, mas, por metonímia, o 'produto' que a contém (cf. cabeleira, por exemplo), apresentando portanto um sentido cristalizado.

\begin{tabular}{|c|c|c|}
\hline Sufixos & Bases simples & Bases complexas \\
\hline$-a d(a, o)$ & $\begin{array}{l}\text { bispado, boiada, cilindrada, ducado, } \\
\text { garotada, guitarrada, papelada, } \\
\text { passarada, pequenada }\end{array}$ & $\begin{array}{l}\text { comissariado, eleitorado, estudantada, } \\
\text { padralhada, professorado, proletariado, } \\
\text { trastalhada, vidralhada }\end{array}$ \\
\hline -agem & folhagem, ladroagem, plumagem, tubagem & fadistagem, quilometragem \\
\hline$-\operatorname{alh}(a, o)$ & cangalbo, cascalbo, politicalha & criançalha \\
\hline$-a m(e, a)$ & cordame, mourama, mulherame, velame & vasilhame \\
\hline$-\operatorname{ari}(a)$ & escadaria, louçaria & leprosaria, tinturaria \\
\hline -ári(o) & $\begin{array}{l}\text { balsamário, preçário, reptilário, temário, } \\
\text { vocabulário }\end{array}$ & mobiliário \\
\hline$-a t(o)$ & $\begin{array}{l}\text { baronato, colonato, inquilinato, } \\
\text { patronato, pensionato, sultanato }\end{array}$ & cavaleirato \\
\hline$-e d(o)$ & $\begin{array}{l}\text { arvoredo, folhedo, fraguedo, lajedo, } \\
\text { mosquedo, silvedo, vinhedo }\end{array}$ & figueiredo \\
\hline$-i a^{22}$ & directoria & burguesia, fidalguia \\
\hline$-i o 23$ & mulherio, rapazio & comadrio, compadrio, cunhadio \\
\hline
\end{tabular}

Quadro II.6. Sufixos formadores de nomes denominais coletivos

1.Sufixo $-\operatorname{ad}(a, o)$

O sufixo - $\operatorname{ad}(a)$ seleciona radicais que denotam seres humanos (criançada, filharada), animais (boiada, passarada), ou objetos

22 De origem grega, este sufixo nominalizador deadjetival foi adotado pelo latim eclesiástico e científico.

23 Este sufixo tem origem latina e já nesta língua formava alguns coletivos (Pharies 2002). 
diversos, como farrapada, papelada ou trastalhada. Exemplos de nomes masculinos são eleitorado, operariado, professorado, proletariado, voluntariado. O sentido coletivo atesta-se, por exemplo, em a criançada/o operariado vai manifestar-se no dia da greve.

Em alguns casos, o derivado remete para um evento/um espetáculo que pressupõe a presença de um conjunto de entidades do mesmo tipo; assim acontece com tourada, em que é protagonista o animal que a base denota; guitarrada, concerto de guitarras.

Os nomes bifalhada, cangalhada, intrigalhada, livralhada, negralhada, padralhada, pretalhada, trastalhada, versalhada, vidralhada são formados a partir duma base derivada em -alh- (cf. Rio-Torto 1993: 446-457), com valor pejorativo, que se mantém nos nomes coletivos.

2.Sufixo -agem

$\mathrm{O}$ sufixo -agem seleciona radicais nominais que podem denotar seres humanos (criadagem, fadistagem, gatunagem), "objetos" naturais (folhagem, plumagem), artefactos (aparelhagem, farrapagem) e unidades de medida (quilometragem, voltagem).

Os nomes de seres humanos acumulam um sentido coletivo e depreciativo (gatunagem), muitas vezes herdado da base.

\section{Sufixo - $\operatorname{alh}(a, o)$}

Os nomes portadores de -alh $(a, o)$ denotam entidades massivas, tipicamente não contáveis, e são marcados pelo traço depreciativo quando remetem para denominações de humanos (gentalha, politicalha). As bases a partir das quais se formam os derivados denotam conjuntos de seres humanos (criançalha, politicalba) ou objetos, materiais, substâncias (cangalho, cascalho).

\section{Sufixo -am $(e, a)$}

Os nomes de quantidade em -am $(e, a)$ podem ter por base radicais de nomes que denotam seres humanos (mourama, mulherame, 
sopeirame), objetos ou artefactos (cadeirame, cordame, dinheirama, vasilhame). Alguns produtos derivados são marcados por depreciação, como sopeirame, mulherame, por vezes porque a base também o é, como sopeira, denotando (PE), na primeira metade do séc. XX, uma 'criada, serviçal'.

\section{Sufixo-ari(a)}

Os nomes sufixados em -ari(a) tomam por base radicais de nomes que denotam ser humano (enfermaria), animais (gataria), materiais naturais (pedraria), mas as bases preferenciais são as que denotam artefactos (escadaria, frascaria, maquinaria).

A leitura quantitativa observa-se em exemplos como a enfermaria agradeceu, emocionada, aos médicos, ou tanta gataria junta não cabe num espaço tão pequeno, ou sograria 'conjunto das sogras', neologismo de Mia Couto.

6.Sufixo -ári(o)

Os nomes derivados em -ári(o) denotam grande quantidade do que as bases representam: produtos intelectuais ou ficcionais (temário, poemário, vocabulário), produtos naturais e vegetais (balsamário, ervário ${ }^{24}$, orquidário), objetos (mobiliário, preçário, sepulcrário, tarifário).

7.Sufixo -at (o)

Os nomes em -at(o) têm por base radicais nominais com o traço [+humano] e denotam coletividades (cf. patronato) e sistemas organizacionais (cf. baronato, colonato, concubinato, inquilinato, sindicato). Regista-se, presentemente, alguma extensão do âmbito semântico das bases, como se comprova, por exemplo, em porcelanato 'conjunto das porcelanas'.

24 O nome herbário tem origem no latim herbariu-, derivado a partir do radical herb-. 
Alguns destes nomes têm também sentido locativo: pensionato 'casa de educação, colégio que recebe alunos internos; internato'; sultanato 'território governado por sultão', vicariato 'território sob jurisdição de um vigário'.

8.Sufixo -ed $(o)$

$\mathrm{O}$ sufixo -ed(o) combina-se com bases radicais de nomes que denotam seres humanos (mulheredo, putedo), animais (mosquedo, passaredo), plantas, árvores, espécies vegetais (arvoredo, bosquedo, figueiredo, vinhedo) e, mais raramente, matérias naturais (fraguedo, lajedo).

Quando a base é um nome de árvore, de espécie vegetal ou de matéria natural, o derivado em -edo denota 'grande quantidade' e/ ou 'espaço, sem limites claros, que contém grande quantidade' do que a base nominal explicita. O significado locativo está presente em, por exemplo, o engenheiro veio do vinhedo animado com a colheita e em o milho está a secar no lajedo.

9.Sufixo $-i(a)$

Os nomes de quantidade em -i(a), como burguesia, diretoria, fidalguia, freguesia, têm por base radicais de nomes com o traço [+humano], respetivamente de burguês, diretor, fidalgo, freguês.

A interpretação coletiva de alguns desses nomes é ilustrável pelos exemplos seguintes: a diretoria encontra-se em reunião há várias horas; a freguesia [conjunto de fregueses] daquela velha mercearia é-lhe sempre fiel.

10.Sufixo $-i(o)$

Os nomes de quantidade em -i(o) têm por base radicais nominais com o traço [+humano] (comadrio, compadrio, cunhadio, mulherio, rapazio) e objeto natural (penedio). Este sufixo nominalizador não se encontra disponível no português contemporâneo. 


\section{Sufixo -et $(o)$}

Este sufixo, de feição erudita, ocorre em nomes de quantidade construídos com base em nominais numerais, como os radicais de (um) duo, (um) terço, (um) quarto, (um) quinto, (um) sexto, em dueto, terceto, quarteto, quinteto, sexteto, respetivamente. Cada um destes nomes sufixados denota uma entidade coletiva (um conjunto musical, uma agremiação, por exemplo) cuja cardinalidade é explicitada pela base ('conjunto de dois, três, quatro, cinco, seis ... elementos ou unidades').

\subsubsection{Nomes locativos}

Os nomes denominais locativos são formados a partir de radicais, a que se juntam diversos sufixos (cf. Quadro II.7). Estes nomes denotam lugares ou espaços onde permanecem ou se albergam determinados seres ou objetos. Trata-se de nomes de espaços naturais ou de espaços configurados em torno daquilo que a base nominal denota e que normalmente existe em grande quantidade nesses espaços ou lugares (canil, choupal, coval, pedreira). Por isso, as fronteiras entre a leitura locativa e coletiva de alguns destes nomes são por vezes relativamente ténues.

Os nomes que designam 'local onde existe uma grande quantidade do que a base representa' são tipicamente sufixados em -al, -ari(a), -ári(o), -ed(o), -eir $(o, a),-i(a),-i l$, sendo -al, -ari(a) e -eir $(o$, a) os mais produzidos.

\begin{tabular}{|l|l|}
\hline Sufixos & Nomes \\
\hline$-\operatorname{ad}(\boldsymbol{o})$ & ducado, laicado, notariado, protetorado, provincialado \\
\hline$-a l$ & $\begin{array}{l}\text { areal, arrozal, batatal, beiral, cadeiral, caniçal, choupal, coval, faval, } \\
\text { funchal, lamaçal, lameiral, laranjal, morangal, palmeiral, pantanal, } \\
\text { penhascal, pinheiral, salitral, tojal, toural }\end{array}$ \\
\hline- ari $(\boldsymbol{a})$ & $\begin{array}{l}\text { cestaria, coudelaria, doçaria, frutaria, judiaria, leprosaria, luvaria, } \\
\text { mouraria, pastelaria, peixaria, perfumaria, sapataria, serralharia, } \\
\text { tesouraria, tinturaria }\end{array}$ \\
\hline
\end{tabular}




\begin{tabular}{|c|c|}
\hline -ári(o) & $\begin{array}{l}\text { aviário, berçário, borboletário, fraldário, infantário, orquidário, ossário, } \\
\text { ranário, reptilário, serpentário, solário }\end{array}$ \\
\hline$-\operatorname{ed}(\boldsymbol{o})$ & arvoredo, ervedo, figueiredo, lajedo, silvedo, vinhedo, urzedo \\
\hline$-\operatorname{eir}(o, a)$ & $\begin{array}{l}\text { coelheira, cristaleira, fogueira, galinheiro, garrafeira, gesseira, lameiro, } \\
\text { marmoreira, palheiro, papeleira, pedreira, penhasqueira, vinagreira }\end{array}$ \\
\hline$-i(a)$ & capitania, feitoria, procuradoria, reitoria \\
\hline$-i l$ & bovil, cabril, canil, gatil, poldril, touril \\
\hline
\end{tabular}

Quadro II.7. Sufixos formadores de nomes denominais locativos

Observe-se que, em função do contexto, alguns nomes, como berçário, enfermaria ou galinbeiro, podem ter, a par com a leitura locativa, uma leitura coletiva:

(1)leitura locativa: o ministro visitou o berçário antes de o inaugurar; a enfermaria fica na ala sul do bospital; o galinbeiro foi reparado numa tarde;

(2)leitura coletiva: o berçário estava divertido com os palbaços; a enfermaria reivindica melhores cuidados médicos; o galinheiro desatou a cacarejar estridentemente.

Para uma mesma leitura concorrem, por vezes, vários sufixos, como se observa através dos seguintes exemplos:

\begin{tabular}{|l|l|l|l|l|l|l|}
\hline Semantismo dos nomes derivados & \multicolumn{3}{l|l}{ Sufixos } \\
\hline $\begin{array}{l}\text { (i) local onde existem ou estão } \\
\text { reunidos: }\end{array}$ & -al & $\begin{array}{l}\text {-ari(a), } \\
\text {-ári(o) }\end{array}$ & -ed(o) & -eir(o,a) & $\begin{array}{l}\text {-ad(o) } \\
\text {-i(a) }\end{array}$ & -il \\
\hline $\begin{array}{l}\text { - animais: pombal; vacaria; serpentário; } \\
\text { coelheira; galinheiro; gatil }\end{array}$ & + & + & & + & & + \\
\hline $\begin{array}{l}\text { - seres humanos, identificados pelo } \\
\text { estado físico (enfermaria), pela etnia } \\
\text { judiaria), pela idade (infantário) }\end{array}$ & & + & & & & \\
\hline $\begin{array}{l}\text {. espécies vegetais: arrozal, arvoredo, } \\
\text { choupal, faval, frutaria, orquidário, } \\
\text { vinhedo }\end{array}$ & + & + & + & & & \\
\hline $\begin{array}{l}\text { - matérias/substâncias naturais: areeiro, } \\
\text { lajedo, lameiro, pantanal, pedreira, } \\
\text { penhascal, salitral }\end{array}$ & + & & + & + & & \\
\hline
\end{tabular}




\begin{tabular}{|l|l|l|l|l|l|l|}
\hline $\begin{array}{l}\text { objetos fabricados ou locais } \\
\text { construídos: beiral, cadeiral, fraldário, } \\
\text { ossário, sapataria }\end{array}$ & + & + & & & & \\
\hline $\begin{array}{l}\text { (ii) espaço onde se desenvolve } \\
\text { atividade, função ou cargo centrados } \\
\text { no que a base denota: cestaria, } \\
\text { coudelaria, notariado, pastelaria, } \\
\text { procuradoria, reitoria, solário }\end{array}$ & & + & & & + & \\
\hline
\end{tabular}

Quadro II.8. Distribuição dos sufixos por subclasses semânticas dos nomes derivados

Dos sufixos elencados, os que se encontram disponíveis para a formação de novos nomes são -ári(o) (cf. fluviário, oceanário, orquidário, reptilário), -ari(a), -al e, em menor escala, -ed(o), -eir(o, a), $-\operatorname{ad}(o),-i(a)$ e -il. De salientar que -il só se combina com nomes de animais, -eir $(o, a)$ com nomes de matérias ou substâncias naturais, - $-a d(o)$ e -i(a) com nomes de ser humano (notariado, reitoria). O sufixo -ed(o) combina-se com bases que denotam espécies vegetais e matérias naturais e os demais sufixos (-ári(o), -ari(a), -al) são os mais versáteis no que à semântica das bases diz respeito.

\subsubsection{Nomes de profissionais de atividade}

Os nomes denominais de profissionais ou de agentes de atividade têm na base um radical e são essencialmente sufixados em -ári(a/o) (não disponível, no presente), em -eir(a/o) e em -ist(a), significando "profissional relacionado com o que a base denota":

\begin{tabular}{|l|l|}
\hline Sufixo & \multicolumn{1}{c|}{ Nomes } \\
\hline -ári $(\boldsymbol{o} / \boldsymbol{a})$ & escriturário, ferroviário, latifundiário, mesário, onzenário \\
\hline -eir $(\boldsymbol{a} / \boldsymbol{o})$ & $\begin{array}{l}\text { armeiro, banqueiro, boieiro, cabeleireiro, carroceiro, ceifeiro, cesteiro, } \\
\text { correeiro, doceiro, falcoeiro, feiticeiro, faroleiro, fazendeiro, ferreiro, } \\
\text { jardineiro, jornaleiro, marinheiro, mineiro, mochileiro, pedreiro, peixeiro, } \\
\text { porteiro, queijadeiro, rendeiro, santeiro, sapateiro, seareiro, serralbeiro, } \\
\text { sorveteiro, vidraceiro }\end{array}$ \\
\hline
\end{tabular}




\begin{tabular}{|l|l|}
\hline- ist $(\boldsymbol{a})$ & $\begin{array}{l}\text { acordeonista, aderecista, alfarrabista, artista, automobilista, balconista, } \\
\text { camionista, caricaturista, cardiologista, carteirista, desportista, }, \\
\text { bumorista, jornalista, lojista, maquinista, mineralogista, musicista, }, \\
\text { neurologista, paisagista, patologista, pianista, sexologista, taxista, } \\
\text { toxicologista, trompetista, velocipedista, vitrinista }\end{array}$ \\
\hline
\end{tabular}

Quadro II.9. Sufixos formadores de nomes denominais de profissional

Aos nomes em -ist(a) pode estar associada uma significação de 'especialista em $x$ ' (musicista 'especialista em música'), em que $x$ remete para a denotação do radical de base. Essa significação não se encontra presente em denominações de atividades que requerem menor especialização, como balconista, florista, lojista, por exemplo. As denominações que têm por base nomes de instrumentos musicais, como acordeonista, baixista, baterista, flautista, guitarrista, pianista, saxofonista, trompetista, não remetem para especialistas teóricos, mas para instrumentistas. Contrabandista e carteirista não são atividades profissionais legalmente reconhecidas, embora na prática por vezes tenham caráter sistemático.

Os nomes derivados em -eir $(a / o)$ estão tendencialmente associados a atividades, funções e ofícios de cariz mais tradicional e artesanal (boieiro, ceifeiro, cesteiro, correeiro, guarda-soleiro, pedreiro, peixeiro, seareiro, serralbeiro) e negativamente conotados, se a base também o é (caloteiro). Mas tal não se aplica a nomes como banqueiro ou engenheiro, que denotam profissionais de atividades socialmente prestigiadas. Recentemente, e por contraste com -ista, -eir- tem sido usado com valor depreciativo (cf. os blogueiros, os festivaleiros, os politiqueiros, os twiteiros).

A base dos nomes que denotam profissionais pode ser o radical de um nome

(i) de objeto: adereço, em aderecista; camion, em camionista (PE) ou camioneiro (PB); cesto, em cesteiro; porta, em porteiro; sapato, em sapateiro; velocípede, em velocipedista; violino, em violinista;

(ii) de animal: boi, em boieiro; peixe, em peixeiro; 
(iii) de matéria: mármore, em marmorista; pedra, em pedreiro;

(iv) de substância: aguarela, em aguarelista; ferro, em ferreiro;

(v) de atividade: ceifa, em ceifeiro; desporto, em desportista;

(vi) de instituição: banca, em banqueiro;

(vii) de área ou atividade científica ou especializada: cardiologia, em cardiologista; neurologia, em neurologista; sexologia, em sexologista.

\subsubsection{Nomes de 'continente/contentor'}

Os nomes denominais de 'continente/contentor' denotam artefactos que funcionam como recipientes, recetáculos ou 'contentores/continentes' de $x$, onde $x$ pode estar depositado ou guardado, e em que $x$ representa objetos (agulha, chave, garrafa, papel, pilha, sapato) ou matérias ou substâncias várias (açúcar, cinza, fruta, óleo, sal, tinta, vinagre). Estes nomes têm por base radicais nominais e são formados com os sufixos -ão, -ári(o) e -eir $(a / o)$.

\begin{tabular}{|l|l|}
\hline Sufixos & \multicolumn{1}{|c|}{ Nomes } \\
\hline -ão & eletrão, ersucão, oleão, papelão, plasticão, pilhão, rolhão, vidrão \\
\hline -ári(o) & adagiário, hostiário, incensário, lampadário, preçário, relicário \\
\hline -eir $(\boldsymbol{o}, \boldsymbol{a})$ & $\begin{array}{l}\text { açucareiro, azeitoneira, chaveiro, cigarreira, cinzeiro, cristaleira, } \\
\text { ficheiro, fruteira, garrafeira, louceiro, paliteiro, papeleira, roupeiro, } \\
\text { saboneteira, saladeira, saleiro, sapateira, tinteiro }\end{array}$ \\
\hline
\end{tabular}

Quadro II.10. Sufixos formadores de nomes denominais de continente/contentor

O sufixo disponível para a formação destes nomes é -eir $(a / o)$.

Este sufixo forma nomes de sentido relacional que poderão ser encarados composicionalmente como 'containers' (cf. caneleira, cotoveleira, dedeira, joelheira, nadegueira, narizeira 
(para natação), perneira, pescoceira, tornozeleira), que, todavia, adquiriram sentidos mais lexicalizados não tanto de 'contentores', mas de 'objetos adstritos a $\mathrm{N}$, que revestem $\mathrm{N}$, que protegem N'.

Nas últimas décadas o sufixo -ão tem sido usado para a formação de nomes de objetos onde se depositam matérias diversas para reciclagem, como eletrão, ersucão (de ERSUC, instituição de "Resíduos sólidos do centro, S.a.", de Portugal, que disponibiliza contentores para recolha de lixo), oleão, papelão, pilhão, plasticão, rolhão, vidrão, cujos radicais de base remetem para (material) elétrico, óleo, papel, plástico, pilhas, vidro. Este sufixo é essencialmente avaliativo (cf. cap. 5), explicitando 'intensidade elevada de alguma(s) propriedade(s) do que a base denota' (amigão, casacão). Terá sido este seu valor aumentativo que serviu de base para este seu uso na formação de nomes de contentor, em regra de dimensões apreciáveis.

\subsubsection{Nomes de "fonte" vegetal}

O sufixo -eir $(a / o)$ combina-se com radicais de nomes de plantas, de flores ou de frutos (caju, castanha, coco, cravo, jasmim, pêra, rosa) e de plantas arbustivas (p.e., alecrim, capim, giesta), dando origem a denominações das árvores e/ou das plantas arbustivas que produzem o que a base denota (cf. Quadro seguinte):

\begin{tabular}{|l|l|}
\hline Sufixo & \multicolumn{1}{c|}{ Nomes } \\
\hline eir $(\boldsymbol{a}, \boldsymbol{o})$ & $\begin{array}{l}\text { abacateiro, alecrinzeiro } \\
\text { capinzeiro, castanheiro, cidreira, coqueiro, craveiro, diospireiro, feijoeiro, figueira, } \\
\text { giesteira, groselheira, jasmin }(z) \text { eiro, laranjeira, limoeiro, loureiro, marmeleiro, } \\
\text { palmeira, pereira, pessegueiro, pinheiro, roseira, tamareira, tomateiro, videira }\end{array}$ \\
\hline
\end{tabular}

Quadro II.11. Sufixo formador de nomes denominais de "fonte" vegetal

25 Os nomes que apresentam - $z$ - antes de -eir-, como alecrinzeiro, capinzeiro, jasminzeiro, são nomes atemáticos terminados em vogal nasal acentuada. 


\subsubsection{Nomes de 'conteúdo'}

Por nomes de conteúdo entendem-se os nomes denominais sufixados em - $a d(a)$ que denotam 'porção contida em $x$ ', 'o que está contido em $x$,' 'conteúdo de $x$ ', em que $x$ representa uma variável que designa aquilo que o referente da base pode conter, sejam matérias ou entidades. Assim, uma cabazada é o que está contido ou pode estar contido num cabaz (uma cabazada de cebolas), uma garfada o que, em matéria comestível, pode ser comportado por um garfo, uma ninhada é o que está contido num ninho.

\begin{tabular}{|l|l|}
\hline Sufixo & \multicolumn{1}{|c|}{ Nomes } \\
\hline -ad(a) & $\begin{array}{l}\text { abada, barrigada, cabazada, caldeirada, cilindrada, colherada, fornada, } \\
\text { garfada, ninhada, panelada, tachada, tigelada }\end{array}$ \\
\hline
\end{tabular}

Quadro II.12. Sufixos formadores de nomes denominais de conteúdo

Em alguns casos, e por metonímia, estes nomes denotam 'produto manufacturado em $x$, em que $x$ representa o contentor, tendo portanto conexões semânticas com os nomes descritos na secção seguinte (2.2.8). Assim, tigelada denota 'preparado feito em $x$ ' e, mais especificamente, doce caseiro feito antigamente numa tigela; fornada denota o conjunto de pães cozidos num forno e também o produto dessa cozedura (a próxima fornada sai daqui a cinco minutos).

\subsubsection{Nomes de preparação/preparado à base de}

O sufixo - $a d(a)$, acoplado a um radical nominal, forma nomes de produto ou de "preparação à base de $x$ ", como arrozada e cebolada. São nomes denominais cujas bases radicais denotam a substância suscetível de entrar numa preparação alimentar, o ingrediente dominante do produto: 


\begin{tabular}{|l|l|}
\hline Sufixo & \multicolumn{1}{|c|}{ Nomes } \\
\hline -ad(a) & $\begin{array}{l}\text { arrozada, bananada, cabritada, cebolada, chispalhada, coentrada, } \\
\text { feijoada, laranjada, limonada, marmelada, massada, pessegada, } \\
\text { tripalhada }\end{array}$ \\
\hline
\end{tabular}

Quadro II.13. Sufixo formador de nomes denominais de preparação/ preparado à base de

Estes nomes apresentam um sentido que envolve grande concentração de $x$, uma vez que o preparado 'obtido à base de $x$ ' exige que o produto alimentar que $x$ representa nele esteja contido em dose não mitigada.

\subsubsection{Nomes de golpe/impacto}

Com esta designação identificam-se nomes denominais formados com o sufixo - $\operatorname{ad}(a)$ que significam 'golpe, marca ou ferimento feitos com o que a base denota', 'ato, movimento enérgico realizado com o objeto que a base denota'. Neste último caso, pressupõe-se a intervenção dum instrumento.

\begin{tabular}{|l|l|}
\hline Sufixo & \multicolumn{1}{|c|}{ Nomes } \\
\hline$-\operatorname{ad}(\boldsymbol{a})$ & $\begin{array}{l}\text { alfinetada, bicada, biqueirada, bolada, bordoada, cabeçada, caudada, } \\
\text { chinelada, chicotada, cotovelada, dentada, facada, machadada, navalhada, } \\
\text { palmada, pantufada, patada, pedrada, pincelada, sapatada, tacada, } \\
\text { tesourada, unhada }\end{array}$ \\
\hline
\end{tabular}

Quadro II.14. Sufixo formador de nomes denominais de golpe/impacto

Como base destes nomes pode ocorrer o radical de nomes que denotam:

(i) arma, instrumento suscetível de ferir ou de servir para aplicar um golpe: faca, em facada; navalha, em navalhada; pedra, em pedrada. 
(ii) parte do corpo que pode servir de instrumento de agressão e/ou marca por ela deixada: bico, em bicada; cotovelo, em cotovelada; unha, em unhada.

(iii) objeto que serve de instrumento com o qual se exerce um movimento enérgico e rápido: bola, em bolada, prancha, em pranchada, taco, em tacada.

Em alguns casos, como canelada, o nome denominal denota não só 'ato, movimento enérgico realizado com o objeto que a base denota', mas também 'ato, movimento enérgico realizado no que a base denota', em que esta é portanto objeto afetado.

\subsubsection{Nomes de evento situado espacial e/ou temporalmente}

Por nomes de evento entendem-se os nomes com um significado genérico que pode ser descrito como 'evento ou ocorrência relacionado/a $\operatorname{com} x$ ' e em que o evento pode manifestar-se sob a forma de uma revolta, uma revolução, uma movimentação, uma celebração.

Estes derivados, também sufixados em $-\operatorname{ad}(a)$, têm por base radicais de nomes de três tipos:

(i) de ser humano, como cabano, em cabanada (nome de uma sedição dos cabanos em Pernambuco e Alagoas, Brasil) e pátria, em patriada (ação ou rebelião malograda, como a dos índios chamados "pátrias", no Rio Grande do Sul, Brasil);

(ii) de topónimo, como em belenzada, 'revolta política ocorrida em Belém (do Pará)';

(iii) de nome de marco ou de período temporal, como abrilada, com origem na revolta liderada por D. Miguel de Portugal, sucedida em abril; entrudada, folgança carnavalesca que tem 
lugar por ocasião do entrudo; janeirada, revolta absolutista contra D. João VI de Portugal, que ocorreu em janeiro.

No conjunto dos nomes de evento inscrevem-se também os sufixados em -at(a), como discursata, negociata, tocata. Apenas conspirata e passeata são necessariamente deverbais. Nomes como bailata, dançata, discursata, jogata, mamata, negociata, tocata podem ter também origem denominal.

No português do Brasil surgiram formações recentes - apitaço, buzinaço, cadeiraço, panelaço - que denotam 'um evento, uma manifestação produzida com x'. Nomes deste tipo revelam a polivalência semântica do sufixo -aç-, muito usado no Brasil quer como aumentativo (bonitaço, talentaço, tarifaço), quer como denotador de 'golpe praticado com/em x' (batocaço, chifraço, pistolaço), ao mesmo tempo que revelam a permeabilidade entre os sentidos de 'golpe/impacto com x' e de 'evento, manifestação produzida com x'. Ademais, não é claro se apitaço e buzinaço são denominais ou deverbais.

2.2.11 Nomes de sistema doutrinal, ideológico, científico, de mentalidades

O sufixo -ism (o) combina-se com radicais nominais de nomes próprios antroponímicos (Quadro II.15 (i)) e de nomes comuns (Quadro II.15 (ii)):

\begin{tabular}{|l|l|}
\hline Sufixo & \multicolumn{1}{c|}{ Nomes } \\
\hline -ism(o) & $\begin{array}{l}\text { (i) bandarrismo, budismo, calvinismo, chavismo, darwinismo, donjuanismo, } \\
\text { franquismo, leninismo, lulismo, marxismo, quixotismo, platonismo, } \\
\text { petrarquismo, pintassilguismo, sadismo, salazarismo, sebastianismo, sionismo } \\
\text { (ii) alcoolismo, aparelbismo, caprichismo, clientelismo, despesismo, } \\
\text { bumorismo, machismo, mecenatismo, partidismo, rigorismo, sexismo, } \\
\text { tabaquismo, terrorismo, tiismo, vampirismo }\end{array}$ \\
\hline
\end{tabular}

Quadro II.15. Sufixo formador de nomes denominais que denotam sistema doutrinal, ideológico, científico, de mentalidades 
Os nomes sufixados em -ism(o) que têm por base nomes próprios antroponímicos denotam o sistema conceptual, doutrinal, de pensamento, de mentalidades, religioso, ideológico, filosófico, científico relacionado com o que a base denota (budismo, calvinismo, darwinismo, hitlerismo, marxismo, petrarquismo). Mas assim também acontece quando a base denota uma época e sua cultura (quatrocentismo, setecentismo) e/ou as correntes estéticas ou culturais a elas associadas (cf. Barbosa 2012).

Quando a base corresponde ao radical de um nome comum, o derivado denota uma tendência para pôr em prática de forma sistemática ou regular algo relacionado com o que a base significa (despesismo, documentarismo), culto excessivo do que a base denota (aparelhismo, basismo, clubismo, clientelismo, inquilinismo, machismo, milagrismo), simpatia ou inclinação persistente para com o que a base denota (alcoolismo, desenvolvimentismo, divorcismo, partidismo, rigorismo, rotulismo, segredismo, sigilismo, tabaquismo, umbiguismo). Porque estão associados à marca de excesso, estes nomes podem ser marcados negativamente. A grande disponibilidade para formar nomes com este sufixo constata-se pela possibilidade de se combinar com algumas bases verbais, como em concentrismo, deambulismo, transformismo, e até com bases nominalizadas (apriorismo).

Aos nomes em -ism(o) que denotam prática ou atividade desportiva (alpinismo, atletismo, campismo, canoismo, caravanismo, pára-quedismo, surfismo) ou técnico-científica (cateterismo) não estão associadas marcas de polaridade negativa ou positiva. Assim acontece também com os nomes de patologia, como tiroidismo, prostatismo, timpanismo, uterismo, ou quando o nome de base é favoravelmente conotado, como em missionarismo. 


\subsubsection{Nomes técnico-científicos}

Há um conjunto de sufixos que se juntam a bases nominais vernáculas ou neo-clássicas para formar derivados. Estes sufixos são usados essencialmente para formar nomes da esfera das técnicas/ciências, nomeadamente das ciências médicas, da química e da mineralogia. As bases podem ser radicais presos eruditos (por exemplo, do gr. hemat- 'sangue', glic- 'doce', necr- 'morte', ou do lat. lact- 'leite'), ou radicais de palavras usadas como autónomas no léxico do português, tais como ácido, amígdala, cálculo (renal), conjuntiva, fibra, furúnculo, mármore, púrpura, retina, sílica (cf. Quadro seguinte).

\begin{tabular}{|l|l|}
\hline Sufixos & \multicolumn{1}{|c|}{ Nomes } \\
\hline$-\boldsymbol{a t}(\boldsymbol{o})$ & borato, carbonato, clorato, manganato, nitrato \\
\hline $\boldsymbol{- \boldsymbol { e t } ( \boldsymbol { o } )}$ & carboneto, cloreto, fosforeto \\
\hline $\boldsymbol{- \boldsymbol { i n } ( \boldsymbol { a } )}$ & anilina, cafeina, cocaina, purpurina, ,ematina \\
\hline $\boldsymbol{- \boldsymbol { i s m } ( \boldsymbol { o } )}$ & artritismo, tiroidismo, prostatismo, timpanismo, uterismo \\
\hline$-\boldsymbol{i t}(\boldsymbol{e})$ & amigdalite, apendicite, conjuntivite, gengivite, meningite \\
\hline $\boldsymbol{- \boldsymbol { i t } ( \boldsymbol { o } )}$ & clorito, nitrito, sulfito \\
\hline $\boldsymbol{- o m}(\boldsymbol{a})$ & fibroma, granuloma, hematoma, papiloma \\
\hline$-\boldsymbol{o s}(\boldsymbol{e})$ & acidose, calculose, fibrose, furunculose, retinose, silicose \\
\hline
\end{tabular}

Quadro II.16. Sufixos formadores de nomes denominais técnico-científicos

Os sufixos -it(e), -om(a) -os(e) selecionam radicais nominais para derivar, respetivamente, nomes de inflamações (-it $(e))$ associadas a enfermidades, nomes de tumores $(-o m(a))$ e nomes de doenças não inflamatórias (-os $(e))$. O significado dos nomes técnicos com eles formados nem sempre é linearmente apreensível, sendo necessário recorrer a dicionários para o identificar. Por exemplo, lactose denomina 'açúcar do leite resultante da união de uma molécula de glucose com uma molécula de galactose'. A sacarose é o nome científico do 'composto principal componente 
do açúcar' (do gr. sakkaros). A lenhite ou lignite, do radical latino lignu- 'madeira', denota 'carvão fóssil, em que se reconhecem ainda os restos de vegetais, de cor castanha ou negra, que arde com muito fumo'.

O sufixo -it (e) combina-se também com radicais de nomes comuns (álcool, assembleia, bricolagem, clube, pacote (económico)), tais como em alcoolite, assemblite, bricolagite, clubite, pacotite, e os derivados denotam 'mania, obsessão por aquilo que a base representa'. Com este sentido o sufixo combina-se, ainda que esporadicamente e com valor expressivo, com radicais verbais (bricolite, reunite, surfite 'obsessão por bricolar/reunir/surfar').

Os sufixos -at (o), -et(o) e -it(o) combinam-se com radicais de nomes de matérias naturais, como carbono, cloro, fósforo e formam derivados que denotam sais: carboneto, clorato, cloreto, clorito, fosfato. O sufixo -in (a) combina-se com radicais de nomes de matérias naturais (cf. anil, café, coca) e dá origem a nomes de alcaloides e de álcalis artificiais, como anilina, cafeína, cocaína.

Por último, o sufixo -ism (o) forma nomes de patologias (adenoidismo, artritismo, tiroidismo, prostatismo, timpanismo, uterismo) ou de intoxicação assentes no que o radical de base denota (cantaridismo, nicotinismo).

A estes pode ainda acrescentar-se -oide, que forma nomes técnicos, de significado não totalmente homogéneo, e com base em denominações elas mesmas também já portadoras de informação especializada, como se observa através das descrições extraídas da Infopédia [Em linha]. Porto: Porto Editora, 2003-2013 de albuminoide 'proteína que não é solúvel em água nem em dissolventes e apresenta uma estrutura fibrosa', cristaloide 'botânica: substância albuminosa, em forma de cristal, que faz parte dos grânulos de aleurona (nas plantas); anatomia: cápsula envolvente do cristalino (do globo ocular), trapezoide 'segundo osso da segunda série do carpo, a partir do lado do 
dedo polegar, com forma de trapézio'. Estes nomes denotam entidades que representam uma versão algo atípica ou distorcida das denotadas pela base (cf. planetoide 'pequeno planeta; asteroide'; vacinoide 'falsa vacina'), ou um tipo diferenciado (cf. crinoide, deltoide, diamantoide, hemisferoide, metaloide, meteoroide, tangentoide) e por vezes mais abstrato que o da base (predicatoide, prefixoide, sufixoide, textoide). É provável que alguns nomes provenham da nominalização dos adjetivos, como albuminoide, amiantoide, argiloide, balsamoide, cactoide, cerebroide, coraloide, cuboide, esferoide, hemisferoide, meniscoide, resinoide, tangentoide, tifoide.

\subsubsection{Nomes de 'linguagem hermética'}

Nas últimas décadas, a língua portuguesa tem assistido a uma nova utilização do sufixo -ês; matricialmente adjetivalizador denominal (cf. francês, genovês), este sufixo -ês passou a formar nomes denominais de 'linguagem ou do idioma hermética/o relacionada/o com o que as bases denotam'. Estas são radicais de nomes de pessoas (Coelho/coelhês, Sampaio/sampaiês, políticos portugueses da segunda metade do século XX) de instituições (Benfica, Sporting, clubes de futebol portugueses), de atividades profissionais com algum grau de especialização (por exemplo: do mundo do jornalismo, da economia, da informática, da educação, da política, etc.), e cuja linguagem técnica nem sempre é acessível a não especialistas. No quadro seguinte elencam-se alguns dos exemplos disponíveis.

\begin{tabular}{|l|l|}
\hline Derivado em -ês: 'linguagem hermética' & Denotação associada à base: \\
\hline benfiquês & $\begin{array}{l}\text { profissionais ou adeptos do clube } \\
\text { denominado Benfica }\end{array}$ \\
\hline diplomatês & diplomatas \\
\hline economês & economistas, profissionais de economia \\
\hline
\end{tabular}




\begin{tabular}{|l|l|}
\hline eduquês & profissionais de ciências da educação \\
\hline emigrês & emigrante, profissionais de emigração \\
\hline europês & $\begin{array}{l}\text { profissionais/adeptos da europa [comunidade } \\
\text { europeia] }\end{array}$ \\
\hline futebolês & profissionais de/do mundo do futebol \\
\hline informatês & profissionais de informática \\
\hline jornalês & $\begin{array}{l}\text { jornalistas, profissionais do mundo } \\
\text { jornalístico }\end{array}$ \\
\hline lisbonês & classe intelectual e/ou política lisboeta \\
\hline magalhanês & computador escolar magalhães \\
\hline maternalês & $\begin{array}{l}\text { agentes do ofício maternal (mães, amas, avós, } \\
\text { educadoras) }\end{array}$ \\
\hline mimalhês & mimalho/a \\
\hline modernês & aquele/aquilo que é moderno \\
\hline politiquês & profissionais de política \\
\hline sampaiês & Jorge Sampaio \\
\hline sociologuês & profissionais de sociologia \\
\hline
\end{tabular}

Quadro II.17. Sufixo formador de nomes de 'linguagem hermética'

Como se observa pelos exemplos do quadro anterior, nas bases destes nomes, surgidos nas últimas duas décadas, podem estar também denominações de variados tipos, como emigrantes (emigrês), profissionais de ofício maternal (maternalês), de tudo o que é moderno (modernês), da classe intelectual ou política de uma capital (lisbonês), tendo também nestes casos um sentido depreciativo. Em Maio de 2012, a propósito da utilização infeliz de "o coiso", por parte de um ministro, como denominação substitutiva de 'isso tudo, ou seja, tudo o que dissera antes', surgiu o neologismo coisês.

\subsubsection{Conspecto geral}

Apresenta-se, no quadro seguinte, uma panorâmica geral da distribuição dos sufixos nominalizadores denominais pelas classes semânticas de nomes que ajudam a construir. 


\begin{tabular}{|c|c|c|c|c|c|c|c|c|c|c|c|c|c|}
\hline $\begin{array}{l}\text { Sufixos } \\
\text { de nomes } \\
\text { derivados }\end{array}$ & ato & $\begin{array}{l}\text { ama } \\
\text { ame }\end{array}$ & io & $\begin{array}{l}\text { ia, } \\
\text { edo }\end{array}$ & aria & $\mathrm{ad}$ & ário & eir & ista & ão & \begin{tabular}{|l|} 
al \\
il
\end{tabular} & ismo & ês \\
\hline quantidade & + & + & + & + & + & + & + & & & & & & \\
\hline locativo & & & & + & + & + & + & + & & & + & & \\
\hline $\begin{array}{l}\text { agente } \\
\text { profissional }\end{array}$ & & & & & & & + & + & + & & & & \\
\hline continente & & & & & & & + & + & & + & & & \\
\hline fonte vegetal & & & & & & & & + & & & & & \\
\hline $\begin{array}{l}\text { conteúdo, } \\
\text { golpe, evento }\end{array}$ & & & & & & + & & & & & & & \\
\hline $\begin{array}{l}\text { sistema, } \\
\text { patologia }\end{array}$ & & & & & & & & & & & & + & \\
\hline $\begin{array}{l}\text { linguagem } \\
\text { hermética }\end{array}$ & & & & & & & & & & & & & + \\
\hline
\end{tabular}

Quadro II.18. Distribuição dos sufixos formadores de nomes denominais por classes semânticas

A observação deste quadro permite extrair as seguintes considerações:

(i) há uma grande dispersão sufixal no âmbito da expressão da quantidade, sendo este o domínio servido por um grande número de sufixos (9 em 16); a dispersão é também acentuada nos nomes locativos, sufixados em -i(a), -ari(a), -ed(o), -ad(a), -ári(o), -eir(o/a), -al e -il (8 em 16 sufixos).

(ii) dos sufixos presentes no quadro, há uma significativa coincidência entre os que denotam quantidade e locatividade, sendo -i(a), -ari(a), -ed(o), -ári(o) e -eir(o/a) comuns a ambos os valores;

(iii) -ári(o) e -eir $(o / a)$ são os sufixos semanticamente mais polivalentes: -ári(o) está ao serviço da formação de nomes de quantidade, de local, de continente e de profissional; -eir $(o / a)$ está ao serviço da formação de nomes de local, continente, profissional e fonte vegetal. 
(iv) o sufixo - $a d(a)$ também se apresenta como bastante versátil, pois forma nomes de subclasses várias (conteúdo, preparado à base de, evento, golpe, impacto), em função da natureza semântica da base a que se adjunge.

(v) a formação de nomes de agente de atividade recorre também a três sufixos, -eir $(o / a)$, -ist $(a)$ e -ári $(o / a)$; a estes acresce, no âmbito da composição, o constituinte -log-, que forma nomes de 'estudioso de, especialista em' (gemólogo, musicólogo, sismólogo), por vezes ainda sufixado em -ist(a) (musicologista).

(vi) os sufixos menos polifuncionais, do ponto de vista das classes semânticas de nomes que formam, são -ism(o), -ist(a), -ês e -ão. Em todo o caso, é importante ter em conta que -ism(o) se combina não só com radicais nominais como também com radicais adjetivais, que -ês forma numerosos adjetivos e que - $\tilde{a} o$ funciona essencialmente como avaliativo.

\subsection{Nomes conversos de Adjetivos}

Muitos nomes da língua portuguesa têm origem num processo de conversão de adjetivos. Assim acontece em as cervejeiras 'as fábricas de cerveja', a espiral 'linha curva, ilimitada, descrita por um ponto que dá voltas sucessivas em torno de outro (polo), e do qual se afasta progressivamente; linha curva em forma (de) espiral', os policiais (PB) 'agentes da polícia', os ferroviários 'os trabalhadores das ferrovias', os parlamentares 'representantes eleitos que trabalham no parlamento'.

Estes nomes podem chamar-se 'nomes de relação', pois denotam entidades lato sensu relacionadas com o que a base significa.

São várias as classes de adjetivos que admitem nominalização.

No âmbito dos adjetivos graduáveis, que exprimem propriedades de indivíduo ou de processos concebidos como tendo valores 
numa dada escala, podem dar-se exemplos de adjetivos dinâmicos (trabalhador), estativos (preguiçoso) e valorativos (famoso).

No âmbito dos não graduáveis, os estativos depatronímicos, como brasileiro, canadense (PB), canadiano (PE), francês, guineense, havaiano, polonês ( $\mathrm{PB})$, por exemplo, também nominalizam. Mas outras subclasses admitem a conversão nominal, vindo a denotar classes variadas de entidades ou situações caraterizados pela propriedade focalizada e nominalizada.

Admitem nominalização adjetivos factivos (no sentido de que têm origem em verbos que pressupõem a verdade do seu complemento frásico), como aborrecido, agradável, angustiante, animador, censurável, emocionante, fundamental, imperdoável, impressionante, lamentável, maçador, ocioso, perigoso, perturbador, reprovável, não factivos, como complicado, custoso, urgente e epistémicos, como ideal.

Também adjetivos psicológicos não epistémicos, como ansioso, esperançoso, impaciente, responsável admitem nominalização.

Em função da semântica do adjetivo de base, os nomes conversos podem denotar propriedades (o agradável, o angustiante, o complicado, o custoso, o fundamental, o ideal, o lamentável, o perturbador da questão é que ...), classes de seres ou de objectos (os moletes 'denominação de um tipo de pão, na região do Porto'), classes de estados (as melhoras) ou seres caraterizados pelas propriedades codificadas (os ansiosos, os esperançosos, os impacientes, os responsáveis, as noviças, as primeiriças).

Os adjetivos que admitem nominalização podem ser, pois, sob o ponto de vista da sua estrutura morfológica, deverbais e denominais.

No âmbito dos deverbais destacam-se os sufixados em - $d$-, como (o) agregado (familiar), (uma) assoalhada, (o) bordado, (secção dos) classificados, (o) colorido, (o) comprimido, (o) cozido, (a) consoada, (a) criada, (o) criado, (o) duplicado, (o) edificado (urbano), (o) embutido, (o) legado, (a) morada, (a) namorada, (o) namorado, (o) ouvido, (o) penteado, (a) privada, (o) refogado, (o) rugido, (os) sentidos, (o) sombreado, (a) torrada, (o) vestido, entre muitos outros. 
No âmbito dos denominais, destacam-se os que denotam:

- agente de atividade (aeroportuário, ferroviário, medievalista, metalúrgico, protésico, sanitarista, sinaleiro)

- natural, habitante de localidade (açoreano, aveirense, baiano, coimbrão, lisboeta, mirandês, paulista, uberlandense), país (angolano, brasileiro, espanhol, francês, israelita, timorense), região, estado (alentejano, algarvio, beirão, matogrossense, nordestino), continente (americano, asiático, europeu)

- agente de instituição (académico, bancário, banqueiro, parlamentar), de setor profissional (metalúrgico);

- simpatizante ou praticante de sistema ideológico, religioso, civilizacional (budista, fundamentalista, jesuíta, maometano, positivista) e político (monárquico, republicano)

- entidade carcacterizada por uma propriedade ancorada em uma individualidade ou divindade (capricorniano, lazarento, maquiavélico, petrarquista, queirosiano, satânico, sebastianista, socrático);

- ser humano (barrigudo, caloteiro, ciumento, diabético, (os) familiares, interesseiro, humanoide, liceal, manobrista, mentiroso, nervoso, palermoide, trintão, quarentão);

- evento (centenário, saturnais), estado (friacho);

- objeto caraterizado em função de intervalo temporal (diário, periódico, semanário) ou por outra propriedade (um exemplar, uma espiraloide, uma serpentina, um submarino);

- matéria, substância (albuminácea, amiantáceo), parte do corpo (o cristalino, o folhoso [dos ruminantes]);

- espécie animal (bacteriáceo, bacteriano), vegetal (arbustivo, tulipáceo), frutífera (uma marroquina, uma tangerina);

- atividade científica ou artística (africanística; dicionarística), estilo artístico (manuelino, pombalino, vicentino);

- entidade caraterizada por denumeral ordinal (décimo, vigésimo, trigésimo, nonagésimo, milésimo), fracionário (oitavo, 
trintavo, quarentavo) ou multiplicativo (triplo, quádruplo, quíntuplo).

\subsection{Nomes deverbais}

Em função das suas significações, os nomes deverbais podem ser distribuídos por duas classes semânticas: a dos eventos e a dos indivíduos. Cada uma destas classes corresponde a "Regras de Formação de Palavras" distintas, em que cada uma das quais operam afixos distintos, que são em grande parte responsáveis pelo resultado semântico do produto. Os nomes deverbais eventivos possuem como significação primeira a de 'evento'. Os nomes deverbais de indivíduo apresentam como significação primeira uma 'entidade' de caráter concreto que pode situar-se em diferentes domínios denotacionais, tais como 'causa', 'instrumento', 'local', 'recipiente', 'parte de um corpo'. As causas podem ser humanos, animais, vegetais, máquinas, substâncias.

A divisão entre deverbais de indivíduo e deverbais de evento é uma divisão baseada nas significações primeiras que são construídas em cada RFP por cada tipo de afixo. Podem existir significações de 'indivíduo' em nomes cuja primeira significação é de 'evento'. Da mesma maneira, podem existir significações de 'evento' em nomes construídos com afixos que tendencialmente dão origem a significações de 'indivíduo'. Por exemplo, o sufixo -ção forma tipicamente nomes de 'evento', tais como avaliação, trepidação, retaliação. No entanto, um deverbal como assombração significa o 'evento de assombrar', mas também 'aquilo que assombra, fantasma'. Trata-se de um processo de polissemia. Como tal, não vamos considerar a existência de dois lexemas ASSOMBRAÇÃ̃O ${ }^{1}$ e ASSOMBRAÇÃO ${ }^{2}$. Dado que a significação de 'indivíduo' é menos representada e não sistemática nos produtos em -ção, considera-se que -ção opera na Regra de Formação de nomes de acção (evento), mas não na Regra de Formação de nomes 
de agente. Dentro de cada Regra de Formação de Palavras, há possibilidade de se gerarem significações várias que são dependentes semanticamente da significação primeira ${ }^{26}$.

À excepção dos nomes formados com os sufixos -id(o), $-d(a)$, $-i c(e),-\operatorname{del}(a),-c ̧(o)$, os restantes foram alvo de estudo por Rodrigues (2008), onde se encontram elencados na sua totalidade. As significações apontadas foram retiradas do DLP.

As classes semântico-argumentais dos verbos de base utilizadas nesta secção encontram-se descritas em Rodrigues (2008: 165-204).

\subsubsection{Nomes deverbais de evento: bases, sufixos, produtos}

Os nomes deverbais de evento são geráveis por vários sufixos (cf. Quadro seguinte):

\begin{tabular}{|c|c|c|c|}
\hline Sufixos & Produtos deverbais & Sufixos & Produtos deverbais \\
\hline -agem & $\begin{array}{l}\text { filtragem, moagem, } \\
\text { recauchutagem }\end{array}$ & $-\operatorname{eir}(a)$ & $\begin{array}{l}\text { canseira, chafurdeira, chieira, } \\
\text { coceira, quebreira }\end{array}$ \\
\hline$-\operatorname{ari}(a)$ & $\begin{array}{l}\text { branquearia, destilaria, } \\
\text { vozearia }\end{array}$ & $-i c(e)$ & $\begin{array}{l}\text { aldrabice, bisbilbotice, } \\
\text { pedinchice }\end{array}$ \\
\hline$-\tilde{a} o$ & abanão, empurrão, puxão & $-i d(o)$ & estalido, estampido, rugido \\
\hline$-c ̧ \tilde{a} o$ & $\begin{array}{l}\text { combinação, contaminação, } \\
\text { revelação }\end{array}$ & $-\operatorname{ment}(o)$ & $\begin{array}{l}\text { desaparecimento, } \\
\text { envolvimento, } \\
\text { enlouquecimento }\end{array}$ \\
\hline$-c(0)$ & andaço, cansaço, sumiço & $-n c(a)$ & matança, poupança, vingança \\
\hline$-d(a)$ & abalada, chamada, topada & $-n c ̧(o)$ & falbanço, gabanço, rapinanço \\
\hline$-\operatorname{deir}(a)$ & $\begin{array}{l}\text { brincadeira, chiadeira, } \\
\text { choradeira }\end{array}$ & $-n c i(a)$ & $\begin{array}{l}\text { dominância, falência, } \\
\text { presidência }\end{array}$ \\
\hline$-\operatorname{del}(a)$ & $\begin{array}{l}\text { caiadela, partidela, } \\
\text { telefonadela }\end{array}$ & -tóri(o) & $\begin{array}{l}\text { falatório, interrogatório, } \\
\text { parlatório, peditório }\end{array}$ \\
\hline$-\operatorname{dur}(a)$ & $\begin{array}{l}\text { abotoadura, cercadura, } \\
\text { faladura }\end{array}$ & & \\
\hline
\end{tabular}

Quadro II.19. Sufixos nominalizadores e seus produtos deverbais

${ }^{26} \mathrm{O}$ mesmo se aplica, mutatis mutandis, aos três nomes em -dour(o) que denotam 'evento repetido ou continuado' (chiadouro, piadouro, zuidouro), pois este sufixo forma essencialmente nomes de indivíduo. 
Os sufixos -um(e) e -at(a) também se anexam a verbos para a geração de nomes. No entanto, a escassez destes produtos não justifica a inclusão de secções específicas para cada um deles. Com o sufixo - at (a) apenas se encontram os deverbais conspirata, mamata, negociata, passeata, viajata. Do sufixo -um(e) encontram-se somente os nomes ardume (de arder), corrume (de correr), curtume (de curtir), queixume (de queixar), tapume (de tapar) e urdume (de urdir).

Existem também nomes de evento produzidos através do processo de conversão, ou seja, sem operador afixal, como abraço, grito, lavra.

$\mathrm{O}$ 'evento' pode ser concebido e formatado de diferentes formas (no seu decurso, nos seus subeventos, na sua efetivação, na sua culminação), de acordo com o tipo de base e o sufixo presentes no produto. Os diferentes tipos de eventos são:

(i) 'evento dinâmico, temporal e ontologicamente unitário ou homogéneo', como em congelação, avaliação; nos nomes assim formatados não é focado o decurso ao longo do eixo do tempo, mas a sua efectivização final (cf. a avaliação foi desgastante);

(ii) 'evento dinâmico/processo, focado no seu decurso continuado no eixo do tempo e ao nível ontológico', como em amarelecimento, arrefecimento (cf. este arrefecimento inesperado destruiu as culturas);

(iii) ação iterada: 'evento dinâmico, constituído por subeventos idênticos, repetidos em simultâneo ou em sequência, não culminado' (gritaria, zombaria); (iv) ação constituída por subeventos diferentes: 'evento dinâmico, constituído por subeventos distintos' (aterragem, alunagem);

(v) ponto de chegada: 'evento dinâmico, focalizado no ponto de culminação do evento (chegada, grunhido).

Além das significações de evento, estes nomes podem também designar significações não eventivas de caráter mais ou menos concreto. São elas: 
(i) estado: 'não evento abstrato, não dinâmico; representa continuidade temporal e ontologicamente homogénea que resulta de um evento' (atemorização, abafamento);

(ii) resultado: 'entidade concreta que resulta do evento' (galadura, ondulação, declaração).

Os deverbais de evento podem ainda acumular significações de 'indivíduo', como 'causa' (aquecimento, guarnição), 'agente humano' (presidência, pilotagem), 'locativo' (agência, refinaria). Não obstante, os sufixos que se apresentam nesta secção disponibilizam, em conjugação com as bases que selecionam, a significação de 'evento'. A par desta, ocorrem outras significações, que serão explicitadas em cada ocasião.

As classes semântico-sintáticas verbais referidas nesta secção encontram-se trabalhadas em Rodrigues (2008: 165-204).

\subsubsection{Nomes sufixados em -ção}

Este é o sufixo formador de nomes de evento com maior produtividade atual.

O sufixo -ção anexa-se ao tema verbal do particípio passado, como se comprova através dos deverbais formados a partir de verbos da $2 .^{a}$ conjugação, como (embeber) embebido > embebi+ção, (moer) moido > moi $+c ̧ \tilde{a} o$.

O sufixo -ção anexa-se a bases verbais que apresentam as seguintes estruturas morfológicas:

(i) bases simples derivadas (verbos conversos), como documentar/documentação, pavimentar/ pavimentação, resinar/resinação;

(ii) bases simples não derivadas (caiar/caiação, trair/traição, vedar/ vedação); 
(iii) bases complexas não derivadas (aplicar/aplicação, averiguar/averiguação, competir/competição, conservar/conservação);

(iv) bases complexas derivadas por prefixação (abafar/abafação, confraternizar/confraternização, encadernar/encadernação, escavar/escavação, refinar/refinação, etc.), por sufixação (actualizar/actualização, bestializar/bestialização, branquear/branqueação, folbear/folbeação, prontificar/ prontificação, saponificar/saponificação) e por circunfixação (aguerrear/ aguerreação, escarnificar/escarnificação). ${ }^{27}$

Destaca-se a ausência de bases que contêm -ec-e -esc- quer como sufixos, quer como constituintes de um circunfixo (e.g. *amareleceção; *ruboresceção, *envelheceção).

O sufixo -ção não mostra preferência por estruturas ou de caráter erudito ou não erudito, sendo compatível com ambas.

Sob o ponto de vista sintático-semântico, as bases dos deverbais em -ção são sobretudo verbos transitivos causativos (agravar>agravação, sedar $>$ sedação, libertar $>$ libertação), indicadores de um desempenho (governar>governação, coordenar>coordenação, decretar>decretação), resultativos (caramelizar>caramelização, cristalizar>cristalização, gaseificar> gaseificação), ornativos, significando 'prover de, aplicar' (amamentar>amamentação, nomear>nomeação, taxar>taxação) e locativos (acamar>acamação, entronizar>entronização, catalogar>catalogação). Também existem produtos em -ção a partir de verbos inergativos (nidificar> nidificação, raciocinar $>$ raciocinação, tiritar $>$ tiritação) e inacusativos (culminar>culminação, inchar>inchação, ulcerar> ulceração), mas em número muito menor do que os que são formados com base em verbos transitivos (Rodrigues 2008: 313-314).

Os semantismos dos nomes em -ção são:

27 Estes são os operadores que se destacam numericamente dos que constituem as bases dos deverbais em -ção. 
(i) evento, o sentido maioritário (afinação, ancoração, deambulação, proliferação, etc.);

(ii) estado, coincidente temporalmente com o ponto em que se efetua o evento e não concomitante com o decurso desse evento (atemorização, consternação, inquietação);

(iii) resultado (conspiração, dissertação, declaração, ondulação, radiação);

(iv) causa/agente (governação, administração, alimentação, guarnição);

(v) locativo (arrecadação, arrumação, fundição, povoação).

\subsubsection{Nomes sufixados em -ment(o)}

O sufixo -ment(o) é, a seguir a -ção, o que tem maior produtividade na atual sincronia. A forma da base verbal a que -ment(o) se junta é a do tema do particípio passado: aparecimento, desenvolvimento apresentam o tema do particípio (- $i$-), observável em aparecido e em desenvolvido.

As bases verbais, com estruturas de caráter erudito e não erudito, possuem as seguintes caraterísticas morfológicas:

(i) bases simples não derivadas (atar/atamento, cair/caimento, sair/saimento, urdir/urdimento);

(ii) bases simples derivadas (verbos conversos) (cruzar/cruzamento, enxofrar/enxoframento, martelar/martelamento);

(iii) bases complexas não derivadas (empreender/empreendimento, induzir/ induzimento, progredir/progredimento);

(iv) bases complexas derivadas por prefixação (apoderar/apoderamento, desmembrar/desmembramento, enfarinhar/enfarinhamento, esfarrapar/ esfarrapamento, etc.), por sufixação (arejar/arejamento, bombardear/bombardeamento, florescer/florescimento, humedecer/humedecimento, planear/ planeamento) e por circunfixação (apedrejar/apedrejamento, endoidecer/ endoidecimento, entristecer/entristecimento). 
Destaca-se a ausência de bases que contêm -iz- e -ific-, como sufixos ou como constituintes de um circunfixo (e.g. *americanizamento; *unificamento). As raras exceções são atemorizamento e arcaizamento.

Relativamente ao tipo sintático-semântico das bases, estas são maioritariamente causativas (apaziguar/apaziguamento, engrossar/ engrossamento, enrijar/enrijamento) e depois ornativas ('prover de') (embalsamar/embalsamamento, enfarinhar/enfarinhamento, polvilhar/polvilhamento), indicadoras de desempenho (cometer/ cometimento, jurar/juramento, pronunciar/pronunciamento) e locativas (abarracar/abarracamento, amontoar/amontoamento, internar/internamento). Os verbos inergativos e os inacusativos também formam deverbais em -ment(o) (balancear/balanceamento, desfalecer/desfalecimento, esmorecer/esmorecimento, luzir/luzimento, nascer/nascimento, zunir/zunimento), embora em número reduzido comparativamente com os verbos transitivos.

Os semantismos dos produtos em -ment(o) são os seguintes:

(i) evento (o semantismo com maior expressão), formatado tipicamente como processual, em decurso (atropelamento, esbanjamento, manuseamento, policiamento, entre outros);

(ii) estado (abafamento, esgotamento, casamento, arrebatamento, enternecimento), algumas vezes designador de doenças (crestamento, esquentamento, esfriamento, resfriamento, quebramento);

(iii) resultado (arruamento, emparcelamento, retalbamento, seccionamento);

(iv) causa/agente (acompanhamento, aquecimento);

(v) locativo (acampamento, alojamento, estacionamento).

\subsubsection{Nomes sufixados em -agem}

A forma da base verbal a que -agem se anexa é a do radical (moer $>$ moagem, vender $>$ vendagem). Estes exemplos de deverbais 
construídos a partir de verbos de tema em -e (moagem de moer, vendagem de vender) mostram que a configuração do sufixo é -agem.

O sufixo -agem anexa-se a bases verbais preferencialmente não eruditas e com as seguintes estruturas morfológicas:

(i) bases simples derivadas (verbos conversos) (estanhar/estanhagem, laminar/laminagem, albuminar/albuminagem, armazenar/armazenagem, martelar/martelagem);

(ii) bases simples não derivadas (lavar/lavagem, lavrar/lavragem, moer/ moagem, raspar/raspagem);

(iii) bases complexas derivadas formadas por prefixação (abordar/abordagem, alunar/alunagem, amarar/amaragem, engarrafar/engarrafagem, engomar/ engomagem, etc.) e por sufixação (enxamear/enxameagem, marear/mareagem). Na base de dados consultada são escassos os sufixos encontrados: além de -e-, apenas ocorre um exemplo de -iz-(cobaltizar/ cobaltizagem). (iv) As bases complexas não derivadas são extremamente escassas (endereçar/ endereçagem e reportar/reportagem).

Os verbos circunfixados não estão disponíveis para a formação destes deverbais. A grande maioria das bases verbais é resultado do processo de conversão denominal.

Quanto ao tipo sintático-semântico das bases, o sufixo -agem prefere os verbos transitivos. São escassos os verbos inacusativos (passar, parar). Dos transitivos, os mais representativos são os ornativos 'prover de' (niquelar, zincar, platinar, sulfatar, etiquetar, carimbar), os instrumentais (cinzelar, pincelar, esmerilar, espadelar) e os indicadores de desempenho (driblar, pilotar, tutelar). Os verbos inergativos são em número reduzido (arfar, cabotinar, guerrilhar, jardinar). A maioria dos verbos designa atividades técnicas.

Os derivados deverbais em -agem têm diversas significações, de que se destaca a de evento. O sufixo-agem tem a particularidade de codificar eventos de caráter técnico. Como tal, o evento em -agem é 
formatado como sendo constituído por uma série de subeventos e por um ponto de culminação. O caráter técnico resulta na designação de atividades profissionais de tipo mecânico (aramagem, betonagem, bobinagem, estucagem, estanhagem, recauchutagem, resinagem, etc.). O evento designado pode também referir-se ao ponto de culminação do evento (alunagem, aterragem, amaragem, ancoragem).

Além de evento, registam-se os seguintes sentidos: imposto, pagamento, quantia (carretagem, cubagem, desalfandegagem, portagem); causa/agente (arbitragem, pilotagem); locativo (moagem, paragem, passagem); resultado/produto (amostragem, legendagem, moagem, pilhagem, tatuagem); instrumento (conjunto) (agulhagem, aparelhagem, atrelagem, engrenagem).

\subsubsection{Nomes sufixados em $-\operatorname{dur}(a)$}

A forma da base verbal a que $-\operatorname{dur}(a)$ se anexa é a do tema do presente, como o evidenciam os deverbais batedura, bebedura, benzedura, espremedura, mordedura, tecedura, tendedura, varredura, entre outros, formados a partir de verbos da $2 .^{a}$ conjugação. Esta constatação permite também verificar que o sufixo é - $\operatorname{dur}(a)$ e não -ur $(a)$. A ser -ura, /d/ faria parte do particípio passado e, nos deverbais construídos a partir de verbos da $2 .^{a}$ conjugação, a forma da base deveria conter -i- (*batidura, *bebidura) e não -e-, como de facto se apresenta (batedura, bebedura).

O sufixo $-\operatorname{dur}(a)$ anexa-se a estruturas morfológicas de base dos seguintes tipos:

(i) bases simples derivadas (verbos conversos) (albardar/albardadura, grudar/grudadura, limar/limadura, rolhar/rolhadura, sachar/sachadura); (ii )bases simples não derivadas (correr/corredura, cortar/cortadura, coser) cosedura, cozer/cozedura, ferver/fervedura, roer/roedura); 
(iii) bases complexas não derivadas (perfumar/perfumadura, remeter/remetedura, represar/represadura, salgar/salgadura);

(iv) bases complexas derivadas por prefixação (abafar/abafadura, abotoar) abotoadura, encabrestar/encabrestadura, encerar/enceradura, escorrer/escorredura, esgotar/esgotadura), por sufixação (coxear/coxeadura, cuspinhar/ cuspinhadura, estoquear/estoqueadura, rastejar/rastejadura, varejar/varejadura, versejar/versejadura) e por circunfixação (agatanhar/agatanhadura).

Este sufixo mostra preferência por estruturas de caráter não erudito. A maioria das bases é simples não derivada, seguindo-se as bases conversas e as prefixadas por en- e por $a$-.

Em relação ao tipo sintático-semântico das bases, estas são maioritariamente transitivas, mas também há bases inacusativas (gretar/gretadura, inchar/inchadura) e inergativas (miar/miadura, ladrar/ladradura, roncar/roncadura, rosnar/rosnadura). Das bases transitivas, as que apresentam maior disponibilidade são as causativas (brunir/brunidura, chamuscar/chamuscadura, matar/ matadura, moer/moedura, polir/polidura, quebrar/quebradura, tisnar/tisnadura), as ornativas 'prover de' (adubar/adubadura, enlamear/enlameadura, ensaboar/ensaboadura, estercar/estercadura, ferrar/ferradura) e as instrumentais (ligar/ligadura, pentear/ penteadura, sachar/sachadura, serrar/serradura).

As bases designam eventos concretos e não abstratos. Para a formação destes nomes não estão disponíveis verbos psicológicos.

Os produtos têm as seguintes significações:

(i) evento: o sufixo - $\operatorname{dur}(a)$ tem a particularidade de referenciação do evento, ou seja, de identificação de uma ocorrência eventiva destacada do todo referencial (faladura, miadura, revestidura, roncadura); os eventos são de caráter concreto, mas não técnico, ao contrário dos denotados por-agem; (ii) resultado: as significações de resultado têm nestes produtos acepções de 'ferida' (arranhadura, beliscadura, golpeadura, machucadura, picadura, 
pisadura, queimadura), 'porção' (enfiadura, ensaboadura, semeadura), 'restos, resíduos' (cevadura, corredura, limadura, serradura), sendo que estas significações não se constroem a partir de verbos inergativos;

(iii) partes de corpo: embraçadura, enfiadura, sangradura, empunhadura.

\subsubsection{Nomes sufixados em -nci(a)}

A forma da base verbal a que -nci(a) se anexa é a do tema do presente, como o revelam os deverbais formados a partir de verbos da $2{ }^{a}$ conjugação (proceder/procedência) e de $1 .{ }^{a}$ conjugação (culminar/culminância).

Nos nomes derivados de verbos de tema em - $i$ - ocorre uma divergência fonológica relativamente ao expectável, pois verifica-se discrepância entre a VT do verbo base (fluir, gerir, aderir, anuir) e a que ocorre no nome em -nci(a): -e-(fluência, gerência, aderência e anuência). Não é esta razão suficiente para se considerar que o sufixo tem o formato -enci(a). Na realidade, estes nomes em correlação paradigmática com os verbos da $3 .^{a}$ conjugação são herdados do latim. Nesta língua, os verbos que estão na origem dos verbos portugueses tinham tema em -E- 'breve'. Ora, estes verbos latinos convergiram, em português, com os verbos de tema em - $i$-, reduzindo-se as quatro conjugações latinas a apenas três, em português. Nomes como fluência mantêm o formato vocálico da vogal correspondente ao tema latino próximo do original, com /e/. A formação de nomes com este sufixo não é muito corrente atualmente a partir de verbos da terceira conjugação. No entanto, possíveis formações são geradas seguindo-se o esquema (cf. cap. 1: 1.5.4) ou paradigma representável por pares como o de fluir/ fluência. Por isso, a formação a partir de dormir tem o formato dormência e não *dormíncia. Recorde-se ainda que, em latim, os verbos de tema em - $i$ - fazem o particípio presente (cuja forma neutra 
do plural -NTIA está na origem histórica de -ncia) em -IENS, IENTIS, razão que explica o formato de nomes como impediência, correlato de impedir, e resiliência, correlato de resilir. Esta circunstância reforça o poder analógico com -e- para as escassas formações em português a partir de verbos em - $i$ -

O sufixo - nci(a) anexa-se a bases verbais com as seguintes estruturas morfológicas:

(i) bases complexas não derivadas (congeminar/congeminância, preceder/ precedência, recrudescer/recrudescência, transcender/transcendência);

(ii) bases simples não derivadas (culminar/culminância, solver/solvência, tender/tendência, viver/vivência);

(iii) bases simples derivadas (verbos conversos) (fulgurar/fulgurância, rapinar/rapinância, sindicar/sindicância);

(iv) bases complexas derivadas por sufixação (arborescer/arborescência, florescer/florescência, fluorescer/fluorescência, fosforescer/fosforescência, verdejar/verdejância), por prefixação (escorrer/escorrência, excrescer) excrescência) e por circunfixação (ensurdecer/ensurdecência, revivescer) revivescência).

Este sufixo mostra preferência por estruturas de caráter erudito. A maioria das bases é complexa não derivada, seguindo-se as bases simples não derivadas e as sufixadas em -esc-. Os circunfixos que aparecem nas bases contêm o elemento -esc-

Quanto aos tipos sintático-semânticos das bases, o sufixo -nci(a) seleciona sobretudo verbos inacusativos. Os verbos inergativos e os intransitivos estão em pé de igualdade, mas num nível inferior aos inacusativos (cf. Rodrigues 2008: 306-309). Os verbos inacusativos são sobretudo designadores de estado/existência (sobreviver/sobrevivência, subsistir/subsistência, tender/tendência, urgir/urgência, vagar/vagância, valer/valência, viger/vigência, viver/vivência), incoativos (arborescer/arborescência, arder/ardência, deliquescer/ 
deliquescência, desfalecer/desfalecência, efervescer/efervescência, ensurdecer/ensurdecência, entumecer/entumecência) e indicadores de movimento com direção específica (descender/descendência, exorbitar/exorbitância, proceder/procedência, reentrar/reentrância, transcender/transcendência). Os verbos transitivos são sobretudo indicadores de desempenho (dominar/dominância, traficar/ traficância, vigilar/vigilância) e causativos (acrescer/acrescência, dissolver/dissolvência, solver/solvência). Os verbos inergativos são de indicação de desempenho (implicar/implicância, sindicar/sindicância), de emissão de luz (radiar/radiância, rutilar/rutilância, verdejar/verdejância), de emissão de som (dissonar/dissonância, planger/plangência, ressonar/ressonância, retumbar/retumbância, ribombar/ribombância, sibilar/sibilância) e de emissão de cheiro (recender/recendência).

As bases são tendencialmente caraterizadas por não possuírem um sujeito controlador do evento, mas detentor de propriedades internas que lhe permitem o evento. Os verbos têm caráter durativo.

Os derivados têm as seguintes significações:

(i) estado/qualidade/propriedade: abundância, ardência, dependência, discrepância, incandescência, repugnância, vivência;

(ii) resultado: equivalência, excrescência, intumescência, redundância, referência, sibilância;

(iii) evento, com caráter processual: confluência, convergência, emergência, incidência;

(iv) período de tempo: vacância;

(v) locativo: agência, estância, urgência.

Os produtos deste sufixo apresentam maior número de significações de estado e de resultado do que de evento. Trata-se de um sufixo utilizado em tecnoléxicos científicos. 


\subsubsection{Nomes sufixados em $-n c ̧(a)$}

A forma do verbo a que $-n c ̧(a)$ se anexa é a do tema do presente (correr > corrença).

Quanto à sua estrutura morfológica, as bases verbais com que o sufixo $-n c(a)$ se combina são:

(i) bases simples não derivadas (andar/andança, correr/corrença, vingar/ vingança);

(ii) bases simples derivadas (verbos conversos) (costumar/costumança, esquivar/ esquivança, fartar/fartança, liderar/liderança, maridar/maridança); (iii) bases complexas não derivadas (comparar/comparança, confiar/confiança, perseverar/perseverança);

(iv) bases complexas derivadas por prefixação (abastar/abastança, decrescer/ decrescença, embirrar/embirrança).

Não se encontram bases sufixadas nem circunfixadas.

Este sufixo mostra preferência por estruturas não eruditas, sobretudo simples não derivadas.

Quanto aos tipos sintático-semânticos das bases, estas são dominantemente transitivas e inacusativas, embora as primeiras sejam em número superior. Os verbos transitivos são, na sua maioria, de indicação de desempenho (embirrar/embirrança, gabar/gabança, governar/governança, liderar/liderança, ordenar/ordenança), causativos (bojar/bojança, criar/criança, demudar/demudança, destemperar/ destemperança) e verbos psicológicos, com sujeito experienciador (confiar/confiança, crer/crença, embirrar/embirrança, esperar/esperança, querer/querença). Nos verbos inacusativos destacam-se os verbos incoativos (medrar/medrança, mingar/mingança, crescer/ crescença) e de existência/estado (parar/parança, parecer/parecença, semelhar/semelhança, viver/vivença). As bases inergativas são exemplificadas por andar/andança, militar/militança, entre outros. 
Estes produtos têm semantismos de estado (confiança, perseverança, temperança), evento (espreitança, matança, nascença, vingança) e resultado (lembrança, quebrança, crescença).

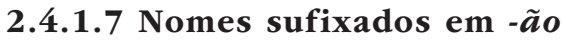

A forma do verbo a que -ão se anexa é a do radical (tropeçar > tropeção).

$\mathrm{Na}$ produção de nomes de evento, o sufixo - ão combina-se com bases verbais que, quanto à estrutura morfológica, são dos seguintes tipos:

(i) bases simples não derivadas (aleijar/aleijão, apagar/apagão, puxar/ puxão, rasgar/rasgão, sacar/sacão);

(ii) bases complexas não derivadas (escorregar/escorregão, estorcegar/estorcegão, recuar/recuão);

(iii) bases complexas derivadas por prefixação (abrasar/abrasão, arrastar) arrastão, encontrar/encontrão, entalar/entalão, repuxar/repuxão, revirar/ revirão);

(iv) bases simples derivadas (verbos conversos) (borrar/borrão, estacar/ estacão).

Não se encontram bases nem sufixadas, nem circunfixadas.

Este sufixo mostra preferência por estruturas não eruditas, sobretudo simples não derivadas.

Para formar nomes eventivos, o sufixo - ão anexa-se sobretudo a bases transitivas que designam eventos que implicam contacto (apalpar/apalpão, apertar/apertão, arranhar/arranhão, arrepelar/ arrepelão, atracar/atracão, calcar/calcão), mover através de força (arrancar/arrancão, arrastar/arrastão, empurrar/empurrão) e ferir (aleijar/aleijão, beliscar/beliscão, entalar/entalão, escaldar/ 
escaldão). As poucas bases inergativas designam sobretudo modo de moção (escorregar/escorregão, tropeçar/tropeção). As bases inacusativas são escassas (recuar/recuão).

Quando - ão se anexa a este tipo de bases verbais, os produtos têm as significações de evento culminado súbito e intenso (empurrão, encontrão, puxão) e de resultado (aleijão, arranhão, beliscão, chupão, escaldão, rasgão). Em 2.4.2.10 é tratada a formação de nomes de indivíduo gerados com este sufixo.

\subsubsection{Nomes sufixados em -ari(a)}

A forma da base verbal a que -ari(a) se anexa é a do radical (gritar > gritaria).

O sufixo -ari(a) anexa-se a bases verbais dos seguintes tipos morfológicos:

(i) bases simples não derivadas (berrar/berraria, gritar/gritaria, serrar/ serraria, voar/voaria, zombar/zombaria, zurrar/zurraria);

(ii) bases complexas derivadas por sufixação em -e- (barbear/barbearia, branquear/branquearia, granjear/granjearia, tornear/tornearia, vozear/vozearia).

(iii) bases simples derivadas (verbos conversos) (aceirar/aceiraria, albergar/ albergaria, alquilar/alquilaria, sesmar/sesmaria).

(iv) Ocorrem escassas bases prefixadas (amassar/amassaria, refinar/refinaria).

Este sufixo não se anexa a bases complexas não derivadas ou bases circunfixadas, mostrando preferência por estruturas não eruditas, sobretudo simples não derivadas.

O sufixo anexa-se a bases transitivas e a bases inergativas, mas não a bases inacusativas. As bases transitivas são preferencialmente de indicação de desempenho (alcovitar, amassar, blasonar, caçoar), ornativas (aceirar, pregar 'pôr pregos', acerar) e causativas 
(branquear, destilar, refinar). As bases inergativas são sobretudo de emissão de som (berrar, zurrar, gritar, roncar).

Os produtos denotam eventos e locativos. O evento designado é constituído por uma iteração de subeventos iguais (gritaria, palraria, roncaria). Quando a base é transitiva, o derivado pode designar atividade profissional (refinaria, marchetaria). A significação de locativo só ocorre com bases transitivas (albergaria, branquearia, destilaria, estamparia, hospedaria, refinaria, serraria), mas não com bases inergativas.

\subsubsection{Nomes sufixados em $-n c ̧(o)$}

A forma da base verbal a que - $n c ̧(o)$ se anexa é a do tema do presente (armar > armanço).

As bases verbais com que o sufixo $-n c ̧(o)$ se combina são, quanto às suas estruturas morfológicas:

(i) bases simples não derivadas (falhar/falhanço, gabar/gabanço, gamar/ gamanço);

(ii) bases simples derivadas (verbos conversos) (amigar/amiganço, palmar/ palmanço, rapinar/rapinanço);

(iii) bases complexas derivadas por prefixacão em en- e es- (empinar/empinanço, entalar/entalanço, espalhar/espalhanço);

(iv) escassas bases complexas não derivadas (habilitar/habilitanço).

Não se encontram bases circunfixadas nem sufixadas.

Este sufixo mostra preferência por estruturas não eruditas, sobretudo simples não derivadas.

No que diz respeito aos tipos sintático-semânticos das bases, o sufixo tem preferência por bases transitivas e, em menor escala, por bases inacusativas. As bases inergativas são escassas. As bases 
transitivas são sobretudo indicadoras de captura/roubo (gamar/ gamanço, palmar/palmanço, pescar/pescanço, pilhar/pilhanço, rapinar/rapinanço, surripiar/ surripianço) e de desempenho (falhar/ falhanço, mimar/mimanço, picar/picanço). As bases inacusativas indicam colocação em configuração espacial (espalhar-se/espalhanço, espetar-se/espetanço, esticar-se/esticanço).

Os produtos apresentam os semantismos de evento processual (gamanço, rapinanço, nicanço) e de evento que indica o ponto de culminação (espalhanço, espetanço, esticanço).

\subsubsection{Nomes sufixados em -id(o)}

Aparentemente, os produtos como latido, gemido parecem corresponder ao particípio dos verbos em - $i$ - e -e-. No entanto, o facto de existirem nomes deste tipo a partir de verbos de tema em -a- legitima a existência do sufixo -id(o) (ladrar > ladrido, rosnar $>$ rosnido). Trata-se de um sufixo extremamente homogéneo na seleção das bases e no contributo semântico para o produto final.

O sufixo anexa-se ao radical verbal (grasnar > grasnido, roncar $>$ ronquido) de bases simples não derivadas, como ladrar/ladrido, zumbir/zumbido, mugir/mugido, roncar/ronquido.

Em termos sintático-semânticos, o sufixo anexa-se a verbos inergativos de emissão de som (bufar/bufido, carpir/carpido, estalar/ estalido, ganir/ganido, gemer/gemido, grasnar/grasnido).

Os semantismos produzidos são de evento (emissão de som), denotando o produto emissão de som (bufido, gemido, grasnido, estalido, zumbido), e de resultado, sendo que o produto designa o próprio som resultante do evento. As duas significações podem distinguir-se em co-texto: em $O$ zumbido durou toda a noite, o verbo aspetual durativo providencia a leitura eventiva; em $O$ zumbido é agudo, o emprego do adjetivo agudo facilita a leitura resultativa. 


\subsubsection{Nomes sufixados em $-i c(e)$}

O sufixo combina-se com o radical da base verbal (aldrabar $>$ aldrabice, bisbilbotar > bisbilbotice). O sufixo prefere bases não eruditas e não derivadas, como chafurdar/ chafurdice, enzonar/enzonice, farfalhar/farfalbice, palrar/palrice, paparrotar/paparrotice, resmungar/resmunguice, havendo também algumas bases simples derivadas, ou seja, conversas (chicanar/chicanice, taramelar/taramelice) e sufixadas (pedinchar/pedinchice).

Quanto aos tipos sintático-semânticos, as bases são inergativas e transitivas. Em comum a estes dois tipos está o semantismo de desempenho (bisbilhotar/bisbilbotice, chafurdar/chafurdice, pedinchar/pedinchice) ou de produção de ato de fala (coscuvilhar/ coscuvilbice, resmungar/resmunguice, tagarelar/tagarelice) marcados com um juízo de valor negativo. Também os produtos denotam um evento marcado como avaliado negativamente (bisbilhotice, pedinchice, palrice), como os demais nomes em -ice (cf. cap. 2: 2.1.2.2).

\subsubsection{Nomes sufixados em $-d(a)$}

O sufixo tem a configuração $-d(a)$. Quando a base é um verbo de tema em - $e$ - ou em - $i$ - preserva-se o tema do particípio verbal (ouvida, mexida, saída).

O sufixo - $d(a)$ anexa-se a bases verbais que, quanto à sua estrutura morfológica, são dos seguintes tipos:

(i) bases simples não derivadas (bolçar/bolçada, caçar/caçada, ir/ida, miar) miada, mexer/mexida);

(ii) bases simples derivadas (verbos conversos) (laçar/laçada, malhar/malhada, peneirar/peneirada, remar/remada); 
(iii) bases complexas derivadas por prefixação em a- (aportar/aportada, atirar/atirada), des- (descair/descaída, descamisar/descamisada, descortiçar/descortiçada), en- (empalhar/empalhada, enfiar/enfiada), es- (espalhar/ espalhada, esquentar/esquentada), re- (rebater/rebatida, recair/recaída, remexer/remexida), por sufixação em -e-(sapatear/sapateada, vozear/vozeada), em -ej- (marejar/marejada, vaquejar/vaquejada) e por sufixação avaliativa (chapinhar/chapinhada, chapiçar/chapiçada, chamuscar/chamuscada); (iv) e, em menor número, bases complexas não derivadas (anunciar/anunciada, consoar/consoada, cavalgar/ cavalgada, despedir/despedida).

Este sufixo mostra preferência por estruturas não eruditas, sobretudo simples não derivadas e complexas derivadas prefixadas. Ocorre uma base circunfixada (amanbecer/amanbecida).

Quanto aos tipos sintático-semânticos, as bases são sobretudo transitivas e inergativas, mas também existem bases inacusativas. As bases transitivas são preferencialmente designadoras de desempenho (caçoar/caçoada, mamar/mamada, mastigar/mastigada, vencer/vencida) e causativas (cozinhar/cozinhada, debulhar/ debulhada, ferver/fervida, fritar/fritada). Dentro das causativas destacam-se as que denotam 'ferir' (escornar/escornada, ferir/ferida, fustigar/fustigada, picar/picada). Há ainda bases transitivas ornativas 'prover de' (calçar/calçada), de contacto por impacto (abalroar/abalroada, acometer/acometida, nicar/nicada) e de movimento em direção específica (tirar/tirada, puxar/puxada, trazer/trazida). As bases inergativas são sobretudo de emissão de som (chiar/chiada, chilrear/chilreada, chinfrinar/chinfrinada, guinchar/guinchada), de desempenho (marrar/marrada, remar/ remada), de emissão de substância (cuspinhar/cuspinhada, esguichar/esguichada, hissopar/hissopada) e de modo de moção (calcorrear/calcorreada, caminhar/caminhada). As bases inacusativas são sobretudo de movimento em direção específica (cair) caída, chegar/chegada, decair/decaída, descer/descida, ir/ida). 
Tal como o sufixo - $d u r(a)$ (cf. cap. 2: 2.4.1.4), o sufixo - $d(a)$ tem a particularidade de referenciar o evento, codificando a identificação de uma ocorrência eventiva destacada do todo referencial. É esta caraterística semântica de 'referenciação', enquanto individualização do evento, que está na origem de semantismos como 'porção', também presente nos produtos em -dur $(a)$. O evento pode também ser apresentado como processual ou como ponto de culminação, em consonância com a estrutura eventiva do verbo base. Ainda que alguns nomes denotem 'evento rápido e negligentemente efetuado', como é o caso de olhada, este não é um traço inerente a $-d(a)$, no $\mathrm{PE}$, como o atestam os exemplos lavrada, malhada. O semantismo de rapidez é usual no $\mathrm{PB}$, nas numerosas construções em DAR uma $X$-da (dar uma encerada, dar uma lida, dar uma olhada, dar uma pensada, dar uma piscada, dar uma saída, dar uma telefonada) (Cf. Rodrigues 2014).

Os semantismos no PE podem ser muito diversos:

(i) evento que indica o ponto de culminação (calcada, olhada, sacudida, tomada);

(ii) evento processual (caçada, escalada, queimada, segada);

(iii) evento que é especificamente um golpe 28 (escornada, marrada, nicada, palmatoada);

(iv) evento constituído por repetição de subeventos iguais (guinchada, roncada, zurrada);

(v) resultado concreto (ferida, lambuzada, picada);

(vi) porção (fritada 'o que se frita de uma vez'; chapada 'porção de líquido que se atira de golpe'; peneirada 'o que se peneira de cada vez'; pisoada 'porção de qualquer substância (pano, lã, etc.) que se pisoa de uma vez'); (vii) aquilo que é Vdo (bebida, comida, cortada, empreitada, queimada); (viii) locativos (entrada, saída, jazida, pousada);

${ }^{28}$ Para os produtos denominais, veja-se a secção 2.2.9. 
(ix) estado (embrulhada, enrascada);

(x) período de tempo (alvorada, consoada);

(xi) agente (cavalgada 'grupo de pessoas a cavalo', revoada 'bando de aves

a voar');

(xii) evento avaliativo (baralhada, araviada 'algaraviada').

\subsubsection{Nomes sufixados em $-c(o)$}

Este sufixo anexa-se ao tema do particípio das bases (inchado> inchaço, tolbido > tolbiço).

Quanto à sua estrutura morfológica, as bases são simples não derivadas (andar/andaço, cansar/cansaço, lançar/lançaço) e complexas derivadas por prefixação (estirar/estiraço). O sufixo opta por estruturas não eruditas.

Em relação aos tipos sintático-semânticos, as bases são transitivas (cansar/cansaço, lançar/lançaço) e inacusativas (andar/ andaço, arrebitar/arrebitaço, sumir/sumiço). Não se encontraram bases inergativas.

Os produtos denotam evento (andaço, cagaço, estiraço, lançaço, sumiço), estado (cansaço), resultado do evento (inchaço, tolbiço) e instrumento não mecânico (tapiço 'cobertura').

\subsubsection{Nomes sufixados em $-\operatorname{del}(a)$}

O sufixo anexa-se ao tema do presente do verbo base (encher > enchedela).

Pode colocar-se a hipótese de se tratar do sufixo avaliativo -el( $(a)$ que se anexa ao radical do particípio passado (olhada >olhadela, partida >partidela). Esta hipótese vai ao encontro da significação destes produtos, que designam evento culminado ou processual, 
conforme o tipo eventivo da base verbal. Contudo, para a delimitação do sufixo como - dela contribuem os seguintes fatores: o facto de não ser possível formar nomes deste tipo a partir de qualquer nome em -da (alvorada/*alvoradela, chapada/*chapadela, empreitada/*empreitadela , ferida/*feridela); o facto de a maior parte das formas correlatas de verbos de tema em - $e$-(lamber, varrer) terem - - e não - $i$-; o facto de a par de lambidela e partidela coocorrerem lambedela e partedela.

Quanto à estrutura morfológica, dominantemente não erudita, as bases são dos seguinte tipos:

(i) bases simples não derivadas (bater/batedela, cuspir/cuspidela, dizer/ dizedela, esticar/ esticadela);

(ii) bases complexas derivadas por prefixação (amansar/amansadela, descair/descaidela, descascar/descascadela, empalmar/empalmadela, empinar/ empinadela, escaldar/ escaldadela, espreguiçar/espreguiçadela) e por sufixação avaliativa (beijocar/ beijocadela);

(iii) bases simples derivadas (estrumar/estrumedela, fartar/fartadela, ferroar/ferroadela).

No que aos tipos sintático-semânticos das bases diz respeito, o sufixo anexa-se a bases transitivas causativas (tosquiar/tosquiadela, untar/untadela) e de desempenho (lavar/lavadela, limpar/ limpadela, pentear/penteadela, sachar/sachadela, tocar/tocadela, varrer/varredela), inacusativas (cair/caidela, fugir/fugidela, parir/ paridela, virar/viradela) e inergativas (grunbir/grunbidela, grasnar/grasnadela, miar/miadela, rosnar/rosnadela, tossir/tossidela).

Devido ao caráter de 'evento rápido e negligente' do sufixo, paralelo em $\mathrm{PE}$ àquele que se verifica com o sufixo $-d(a)$ em $\mathrm{PB}$ (cf. Rodrigues 2014), pode colocar-se a hipótese de este se agregar apenas a bases eventivamente culminadas. Mas não é isso que se verifica. Na verdade, o sufixo anexa-se a bases que são processos 
culminados (arranjar/arranjadela, assar/assadela), processos (assobiar/assobiadela, borrifar/borrifadela) e culminações (arrancar/ arrancadela, esmagar/esmagadela). O sufixo exclui apenas verbos de estado (amar/"amadela, existir/"existidela, morar/"moradela).

Os produtos apresentam os seguintes semantismos:

(i) evento rápido e/ou negligentemente efectuado (miadela, olhadela, paridela);

(ii) porção (lambedela 'o que se lambe de uma vez', vessadela 'porção de terra que se lavra num dia');

(iii) resultado concreto (amassadela 'amolgadura', arranhadela, borradela, escaldadela, queimadela);

(iv) restos (lambuzadela 'vestígios de comida ou bebida').

\subsubsection{Nomes sufixados em -tóri(o)}

Este sufixo constrói adjetivos, nomes de evento e nomes de indivíduo. Apesar de muitos lexemas que contêm este sufixo apresentarem correspondente em latim, o sufixo mantém-se ativo em português.

As bases, quanto à sua estrutura morfológica, são dos seguintes tipos: bases complexas não derivadas (interrogar/interrogatório); bases simples não derivadas (berrar/berratório, lavar/lavatório, gabar/gabatório); bases simples derivadas (verbos conversos) (pasmar/pasmatório); bases derivadas por prefixação (destampar/ destampatório).

No que diz respeito aos tipos sintático-semânticos das bases verbais, estes são: (i) inergativos designadores de atos de fala e de emissão de som (berrar/berratório, parlar/parlatório); (ii) transitivos causativos (lavar/lavatório, fumigar/fumigatório) e transitivos de atos de fala ou performativos (pedir/peditório, destampar/destampatório, interrogar/interrogatório). 
O semantismo de evento construído por este sufixo carateriza-se por um matiz de reiteração e avaliação (falatório, palratório, berratório, pasmatório, lavatório, fumigatório, destampatório, gabatório), que está ausente dos nomes de indivíduo formados pelo mesmo sufixo. Trata-se de um semantismo que parece produtivo atualmente em domínios não especializados.

\subsubsection{Nomes sufixados em -deir(a)}

O sufixo - $\operatorname{deir}(a)$ anexa-se ao tema do presente (moer $>$ moedeira) e combina-se com bases verbais de estrutura não erudita das seguintes classes morfológicas: (i) bases simples não derivadas (chorar/choradeira) e (ii) bases simples derivadas (verbos conversos) (mamar/mamadeira). O sufixo não se combina com bases afixadas.

Os nomes de evento em - $\operatorname{deir}(a)$ têm por base verbos inergativos de emissão de som (chiadeira, choradeira, fungadeira, ganideira, gritadeira), de emissão de substância (pingadeira) e indicadores de desempenho (brincadeira, dormideira, mamadeira). Em menor número, formam-se nomes a partir de verbos transitivos causativos (, quebradeira, carregadeira), performativos (bebedeira, comedeira, trincadeira) e de estímulo-sujeito (moedeira).

\subsubsection{Nomes sufixados em -eir(o), -eir(a)}

Os sufixos -eir(o) e -eir(a) caraterizam-se pela baixa representatividade na formação de nomes de evento.

O sufixo -eir(a) anexa-se ao radical (zoar > zoeira) e as bases são, no que à sua estrutura morfológica, diz respeito: 
(i) bases simples não derivadas (cansar/canseira, chafurdar/chafurdeira, chiar/chieira),

(ii) bases simples derivadas (verbos conversos), como chinfrinar/chinfrineira;

(iii) bases complexas derivadas por prefixação (abafar/abafeira).

Não estão atestadas bases circunfixadas, nem bases complexas não construídas. O sufixo opta por estruturas morfológicas não eruditas. Quanto aos tipos sintático-semânticos, as bases são: inergativas de emissão de som (chinfrinar, farfalhar, grazinar, gritar), de emissão de substância (bafar, cuspinhar), de desempenho (chafurdar, trabalhar); causativas (abafar, cansar, torrar). Não se encontraram bases inacusativas. Os produtos denotam 'evento reiterado/aumentativo' (abafeira, chieira, cuspinheira, farfalheira, griteira, palreira) e estado (abafeira, canseira, chafurdeira, coceira, quebreira).

O sufixo -eir(o) forma um nome de evento (berreiro) e está também presente no derivado entorneiro 'grande porção de líquido ou de substância entornada pelo chão', que denota um produto.

\subsubsection{Conspecto geral}

No quadro seguinte sumariam-se as significações mais salientes desenvolvidas por cada sufixo de formação de nomes deverbais de evento.

\begin{tabular}{|c|c|c|c|c|c|c|c|c|c|c|c|}
\hline & \multicolumn{11}{|c|}{ Significações } \\
\hline $\begin{array}{l}\text { Sufixos } \\
\text { nomina- } \\
\text { lizadores } \\
\text { de evento }\end{array}$ & ação & $\begin{array}{l}\text { pro- } \\
\text { cesso }\end{array}$ & $\begin{array}{l}\text { ação } \\
\text { itera- } \\
\text { da }\end{array}$ & $\begin{array}{l}\text { ação com } \\
\text { subven- } \\
\text { tos dife- } \\
\text { rentes }\end{array}$ & $\begin{array}{l}\text { ponto } \\
\text { de } \\
\text { che- } \\
\text { gada }\end{array}$ & $\begin{array}{l}\text { Es- } \\
\text { tado }\end{array}$ & $\begin{array}{l}\text { causa/ } \\
\text { agente }\end{array}$ & $\begin{array}{l}\text { Loca- } \\
\text { tivo }\end{array}$ & $\begin{array}{l}\text { imposto, } \\
\text { quantia } \\
\text { paga- } \\
\text { mento }\end{array}$ & \begin{tabular}{|l|} 
resul- \\
tado
\end{tabular} & $\begin{array}{l}\text { perío- } \\
\text { do de } \\
\text { tempo }\end{array}$ \\
\hline -ção & + & & & & & + & + & + & & + & + \\
\hline$-\operatorname{dur}(a)$ & + & & & & & + & + & + & & + & \\
\hline -agem & & & & + & + & + & + & + & + & + & \\
\hline$-\operatorname{ari}(a)$ & & & + & & & & & + & & & \\
\hline -ment $(o)$ & & + & & & & + & + & + & & + & \\
\hline -ão & & & & & + & & & & & + & \\
\hline$-i d(o)$ & + & & & & & & & & & + & \\
\hline
\end{tabular}




\begin{tabular}{|l|l|l|l|l|l|l|l|l|l|l|l|}
\hline$-\boldsymbol{d}(\boldsymbol{a})$ & & + & + & & + & + & + & + & & + & + \\
\hline$-\boldsymbol{n c i}(\boldsymbol{a})$ & & + & & & & + & + & + & & + & + \\
\hline$-\boldsymbol{n c}(\boldsymbol{a})$ & & + & & & & + & + & + & & + & \\
\hline$-\boldsymbol{n c}(\boldsymbol{o})$ & & + & & & + & + & & & & + & \\
\hline$-\boldsymbol{c} \boldsymbol{c}(\boldsymbol{e})$ & & + & + & & & & & & & & \\
\hline$-\boldsymbol{d e l}(\boldsymbol{a})$ & + & & & & + & & & & & + & \\
\hline$-\boldsymbol{u m}(\boldsymbol{e})$ & & + & & & & & & & & & + \\
\hline$-\boldsymbol{a t}(\boldsymbol{a})$ & & + & & & & & & & & & \\
\hline$-\boldsymbol{c}(\boldsymbol{o})$ & & + & & & & + & & & & + & \\
\hline
\end{tabular}

Quadro II.20. Distribuição de sufixos formadores de nomes deverbais de evento

Pela observação deste quadro pode depreender-se que:

a) a significação de 'evento' está presente em diversas significações eventivas, como as de 'ação', 'evento', 'ação iterada', 'ação constituída por subeventos diferentes', 'ponto de chegada';

b) além das significações eventivas, os produtos gerados com estes sufixos apresentam ainda semantismos de 'estado' e de 'resultado', bem como algumas significações secundárias de 'agente/causa', 'imposto/pagamento/quantia', 'período de tempo' e 'locativo';

c) os sufixos que disponibilizam maior variedade de significações são aqueles que apresentam maior produtividade na formação destes nomes;

d) a significação de 'resultado' anda a par com a de 'estado'. Assim, os sufixos cujos produtos apresentam o semantismo de 'estado' geralmente também disponibilizam o de 'resultado'. É este o caso de -ment(o), -dur(a), -ção, -agem, -d(a), $-n c i(a),-n c ̧(a),-n c ̧(o)$ e $-c ̧(o)$. São exceção a esta correlação os produtos de -ão e de -id(o).

e) os sufixos $-\operatorname{dur}(a)$ e -ção formam produtos cujas significações de 'evento' designam 'ações'; os sufixos -ment(o), $-d(a)$, -nci(a), -nç(a), -nç(o), -ic(e), -um(e), -at(a) e -ç(o) designam 'processos'; os produtos de -agem designam 'ação constituída por subeventos diferentes'; os nomes deverbais em -ari(a) 
denotam eventos que são 'ações iteradas'; os produtos de $-d(a)$ e -ic(e) também mostram 'ação iterada'.

No quadro seguinte condensa-se a informação relativamente às estruturas sintático-semânticas das bases escolhidas pelos sufixos.

\begin{tabular}{|c|c|c|c|}
\hline \multirow[b]{2}{*}{ Sufixos nominalizadores de evento } & \multicolumn{3}{|c|}{ Tipos de bases } \\
\hline & inergativas & transitivas & inacusativas \\
\hline$-c ̧ \tilde{a} o$ & + & + & + \\
\hline$-\operatorname{dur}(a)$ & + & + & + \\
\hline -agem & + & + & + \\
\hline$-\operatorname{ari}(a)$ & + & + & \\
\hline$-\operatorname{ment}(o)$ & + & + & + \\
\hline$-\tilde{a} \boldsymbol{o}$ & + & + & \\
\hline$-i d(o)$ & + & & \\
\hline$-d(a)$ & + & + & + \\
\hline$-n c i(a)$ & + & + & + \\
\hline$-n c ̧(a)$ & + & + & + \\
\hline$-n c ̧(o)$ & + & + & + \\
\hline$-i c(e)$ & + & + & \\
\hline$-\operatorname{del}(a)$ & + & + & + \\
\hline$-u m(e)$ & & + & + \\
\hline$-a t(a)$ & + & + & \\
\hline$-c ̧(o)$ & & + & + \\
\hline
\end{tabular}

Quadro II.21. Distribuição de sufixos formadores de nomes deverbais de evento por classes sintático-semânticos de bases

Alguns sufixos mostram preferência relativamente a algumas bases:

a) os sufixos -ção, -dur(a), -agem, -ment (o), -ão, -d(a), -nci(a), $-n c ̧(a),-n c ̧(o),-\operatorname{del}(a)$ anexam-se a qualquer tipo de base. No entanto, o sufixo -ncia(a), embora se anexe aos três tipos de bases, acopla-se a maior número de bases inacusativas e o sufixo - ão, na geração de nomes eventivos, adota preferencialmente verbos transitivos e inergativos;

b) o sufixo - $i d(o)$ apenas se anexa a verbos inergativos de emissão de som; 
c) os sufixos -ic(e), -ari(a) e -at(a) excluem bases inacusativas;

d) os sufixos $-c(o)$ e $-u m(e)$ não se anexam a bases inergativas.

\subsubsection{Nomes de indivíduo: bases, sufixos, produtos}

Os nomes deverbais de indivíduo são formados por sufixos que, prototipicamente, dão origem a nomes com semantismos concretos 29. Os sufixos que constroem estes semantismos são apresentados por ordem decrescente de representatividade:

\begin{tabular}{|c|c|c|c|}
\hline $\begin{array}{l}\text { Sufixos } \\
\text { formadores de } \\
\text { nomes deverbais } \\
\text { de 'individuo' }\end{array}$ & Produtos & $\begin{array}{l}\text { Sufixos } \\
\text { formadores de } \\
\text { nomes deverbais } \\
\text { de 'indivíduo' } \\
\end{array}$ & Produtos \\
\hline$-d o r$ & $\begin{array}{l}\text { amortecedor, dador, } \\
\text { nadador, navegador }\end{array}$ & $-\operatorname{eir}(\mathrm{a})$ & ceifeira, coalbeira \\
\hline$-\operatorname{dor}(\mathrm{a})$ & $\begin{array}{l}\text { escavadora, } \\
\text { metralhadora }\end{array}$ & $-\operatorname{eir}(0)$ & calceteiro, trafegueiro \\
\hline$-\boldsymbol{n t}(\mathrm{e})$ & $\begin{array}{l}\text { arguente, corante, } \\
\text { desmaquilbante, } \\
\text { detergente }\end{array}$ & $-e t(a)$ & chupeta, escalfeta \\
\hline$-\operatorname{dour}(\mathrm{o})$ & $\begin{array}{l}\text { bebedouro, } \\
\text { respiradouro }\end{array}$ & $-a l b(0)$ & espantalbo, esfregalbo \\
\hline$-\operatorname{dour}(\mathrm{a})$ & $\begin{array}{l}\text { espalbadoura, } \\
\text { roçadoura }\end{array}$ & $-a l b(a)$ & acendalba, aralba \\
\hline$-\tilde{a} \boldsymbol{o}$ & chorão, picão & $-\boldsymbol{e l b}(\mathrm{o})$ & rapelbo \\
\hline -vel & dirigível, variável & $-\boldsymbol{i l b}(\mathrm{a})$ & cortilha, raspilha \\
\hline$-\operatorname{deir}(\mathrm{o})$ & desfiladeiro, picadeiro & $-\boldsymbol{i l h}(\mathrm{O})$ & atilbo, peguilbo \\
\hline$-\operatorname{deir}(\mathrm{a})$ & cantadeira, lançadeira & $-\boldsymbol{u} \boldsymbol{l b}(\mathrm{o})$ & tapulbo \\
\hline -óri(a)/tóri(a) & $\begin{array}{l}\text { conservatória, } \\
\text { convocatória }\end{array}$ & $-\operatorname{tiv}(\mathrm{o}) / \boldsymbol{i v}(\mathrm{o})$ & comprovativo, sedativo \\
\hline -óri(o)/tóri(o) & $\begin{array}{l}\text { conservatório, } \\
\text { lavatório }\end{array}$ & $-t i v(a) / i v(a)$ & afirmativa, iniciativa \\
\hline$-a l$ & estendal, tendal & -tári(o)/ári(o) & $\begin{array}{l}\text { arrendatário, } \\
\text { dispensário }\end{array}$ \\
\hline
\end{tabular}

Quadro II. 22. Sufixos formadores de nomes deverbais de 'indivíduo' e seus produtos

29 Para a formação de adjetivos deverbais veja-se a secção 3.3 . 
Os produtos dos sufixos -nt (e), -dor, $-\operatorname{dour}(o),-\operatorname{dour}(a),-\operatorname{dor}(a)$, -ão, -vel, -deir(o), -deir(a), -óri(a)/-tóri(a), -óri(o)/-tóri(o) e -al foram alvo de estudo em Rodrigues (2008), onde se encontram circunstanciadamente descritos.

Optámos por considerar as formas femininas (-dour $(a),-\operatorname{deir}(a))$ separadamente das masculinas (dour $(o),-\operatorname{deir}(o))$ pelo facto de o contraste de género nestes nomes deverbais corresponder muitas vezes a uma significação especializada, quer no masculino, quer no feminino ${ }^{30}$. A diferença entre velejador/velejadora e metralhador/ metralhadora ilustra esta realidade. Entre velejador e velejadora apenas ocorre alternância de género sem alteração no significado lexical. Quando assim acontece, registam-se apenas as formas masculinas, por corresponderem às não marcadas. Já em metralhador e metralhadora a significação de 'instrumento' da forma feminina não está presente na forma masculina metralhador. Nesta situação, são também consideradas as formas femininas, pois estão lexicalizadas.

Optámos também por destacar o marcador de classe em relação ao morfema do sufixo em si mesmo, colocando-o entre parênteses. Mesmo nas situações em que não ocorre variação de marcador de classe, como nos derivados em -nt(e), deve respeitar-se a identidade fonológica do sufixo, mais visível em operações que envolvem a anexação de outros sufixos. Face a corrent(e), em corrent+inh(a), o - $e$ final não se mantém no derivado, pelo que não pertence ao sufixo - nt (e). Por outro lado, mantemos a presença desses marcadores de classe para facilitar a leitura dos lexemas em causa.

Os semantismos concretos apresentados pelos produtos destes sufixos são de vários tipos:

(i) agente humano: instigador humano de um evento (avaliador, outorgante);

30 Também na tradição lexicográfica as formas não marcadas (geralmente o masculino) são tomadas como as representativas do todo e apenas se explicitam as femininas que se distanciam das primeiras por apresentarem semantismos próprios. 
(ii) agente/causa não especificado quanto ao caráter [ \pm humano]: instigador de evento (derivativo) ${ }^{31}$;

(iii) substâncias: espécies de matéria (adoçante, carburante);

(iv) vegetais: (trepadeira 'planta', engatadeira 'planta');

(v) animais (trepadeira 'ave', saltão 'gafanhoto');

(vi) instrumentos mecanizados (escavadora, britadeira);

(vii) instrumentos não mecanizados (abridor, frigideira);

(viii) experienciador (lastimador, sofredor);

(ix) locativos (corredor, passadeira);

(x) locativos causativos: trata-se de locais que instigam o evento (germinadouro 'lugar onde se faz germinar a cevada para o fabrico da cerveja', incubadora);

(xi) partes de um corpo ou instrumento (respiradouro 'orifício destinado a deixar entrar e sair o ar', ruminadouro 'estômago dos ruminantes');

(xii) recipientes/contentores (defumador, esquentador).

Um esclarecimento é ainda devido aos formatos dos pares -tóri(o)/-óri(o), -tiv(o)/-iv(o), -ári(o)/-tári(o) que optamos por tratar separadamente. Os membros de cada par têm origem no mesmo sufixo latino (Nunes ([1919] 1989: 371); Said Ali (1964: 238); Diez (1874: 327-328); Meyer-Lübke (1895: 579583); Pensado (1999: 4487)) e a variação (com ou sem /t/) depende da forma do terceiro radical 32 a que cada um se unia. Optámos por considerar as duas formas separadamente como sufixos do português pelo facto de as duas servirem a construção de nomes em português, que não têm correspondente em latim.

31 Causa/agente pode não coincidir obrigatoriamente com um argumento da estrutura argumental ou mesmo léxico-conceptual do verbo base, como se verifica através de chovedor ('aquilo que faz chover' e não '*aquilo que chove') ou lambedor ('aquilo que faz lamber' e não 'aquele que lambe').

32 A propósito do terceiro radical veja-se Aronoff (1994: 31-59). 


\subsubsection{Nomes sufixados em -dor}

A forma da base verbal a que -dor 33 se anexa é a do tema do presente (beber > bebedor). O sufixo -dor anexa-se a bases verbais eruditas e não eruditas com as seguintes estruturas morfológicas:

(i) bases simples não derivadas (bramir/bramidor, carpir/carpidor, coser/ cosedor, dar/dador, doar/doador);

(ii) bases complexas não derivadas (adquirir/adquiridor, concatenar/concatenador, remunerar/remunerador);

(iii) bases complexas derivadas por prefixação (abafar/abafador, arrasar) arrasador, descascar/descascador, encaminhar/encaminhador, escavar/ escavador, esborralhar/esborralhador, repatriar/repatriador, repicar/repicador, repuxar/repuxador), por sufixação (bronzear/bronzeador, golear/ goleador, guerrear/guerreador, fortalecer/fortalecedor, varejar/varejador, versejar/versejador, purificar/purificador, falsificar/falsificador, canalizar/ canalizador, categorizar/categorizador) e por circunfixação (amortecer/ amortecedor, rejuvenescer/rejuvenescedor);

(iv) bases simples derivadas (verbos conversos) (capsular/capsulador, datar/datador).

Relativamente aos tipos sintático-semânticos das bases, o sufixo -dor prefere bases transitivas, mas também se combina com bases inergativas e inacusativas. No conjunto das bases transitivas, as mais representadas são as indicadoras de desempenho (administrar) administrador, coordenar/coordenador, correger/corregedor), as causativas (catalisar/catalisador, congelar/ congelador, liquidificar/ liquidificador), as ornativas 'prover de' (estucar/estucador, estofar/ estofador, povoar/povoador), entre muitos tipos sintático-semânticos de grande representatividade.

33 Veja-se cap. 2: 2.4.2.2 para a variação -dor/-dor $(a)$. 
As bases inergativas são sobretudo indicadoras de desempenho (boxear/boxeador, lutar/lutador, trabalhar/trabalhador), de emissão de som (cantar/cantador, chiar/chiador, chilrear/chilreador), de modo de moção (nadar/nadador, navegar/navegador, patinar/patinador), entre outros. As bases inacusativas, embora menos representadas, são sobretudo verbos de estado/existência (sustentar/sustentador, significar/significador), mover-se em direção específica (migrar/migrador, emigrar/emigrador) e aparecimento (deflagrar/deflagrador).

Este sufixo carateriza-se pelo semantismo de [que tem a função de]. Os semantismos construídos através da sua atuação são:
(i) agente humano: avaliador, corredor, mergulhador;
(ii) experienciador: admirador, amador;
(iii) instrumento não mecânico: andador, soprador, abridor;
(iv) instrumento mecânico: aspirador, bidroplanador, detonador;
(v) agente animal ${ }^{34}$ : voador, corredor, galopador.

(vi) recipientes/contentores: cuspidor, defumador 'vaso onde se queimam substâncias para defumar ou aromatizar';

(vii) recipientes/contentores causativos: escalfador, esquentador, melificador 'vaso em que se aquecem os favos para o mel se desprender';

(viii) substâncias: acelerador 'substância que aumenta a velocidade de uma reação química', biocatalisador 'substância (enzima ou hormona) existente nos tecidos vivos, de ação catalítica sobre reações indispensáveis à vida', cintilador 'substância capaz de produzir luminescência';

(ix) partes de corpo: horripilador 'músculo liso que existe na pele, e que, contraindo-se, obriga a levantar o pêlo a que está ligado', abaixador 'depressor (músculo)', (x) locativos (em número muito escasso): corredor, toucador.

${ }^{34}$ A inclusão destes produtos que designam 'agente animal' na classe dos nomes é justificada pelo facto de funcionarem como epítetos designadores de supraespécies (Rodrigues 2008: 509-510). Esta caraterística é visível em enunciados como Esta ave é uma corredora; Esta ave é uma voadora; Este mamífero é um galopador. Estas classes supra-espécie são formuladas pelo senso comum, não carecendo de formulação científica, para que assim possam ser encaradas. 
O semantismo que o sufixo aporta aos produtos é de [que tem a função de], ou seja, de 'algo/ alguém que cumpre uma atividade'. Este traço justifica as seguintes particularidades semânticas:

(i) os recipientes/contentores são, na sua maioria, em simultâneo causadores do evento;

(ii) são mais numerosas as designações de instrumentos do que as designações de substâncias;

(iii) as designações de animais referem sempre um epiteto supra-espécie e não uma espécie;

(iv) as partes do corpo referem-se sempre a partes com função por elas executadas;

(v) os locativos são escassos.

A diferença semântica entre pares corradicais, como governador (do Banco, do Reino) e governante 'pessoa que administra os recursos de uma região ou país', servidor (do Estado, servidor digital) e servente 'criado; subalterno da construção civil', negociador 'aquele que trata de uma negociação' e negociante 'pessoa que negoceia; comerciante' atesta os diferentes valores dos sufixos envolvidos (para $-n t(e)$ ver 2.4.2.7). Em todo o caso, seria interessante verificar se as propriedades deste sufixo e de - nt $(e)$ tendem a manter-se estáveis ou não, e se são comuns ao PE e ao PB atuais, na medida em que existem algumas divergências nas configurações adotadas, como por exemplo em fumador (PE) e fumante (PB), amaciante (PB) e amaciador (PE), conservante/conservador, falante/falador, pedinte/pedidor. A flutuação entre -dor e -nte faz-se sentir também no PE, como o ilustra o exemplo de "O ministro do Planeamento [....] revelou que o detonante para nacionalizar a companhia foi o défice..» (Expresso, Economia, 21.04.2012: 21). Em alternativa, muitos usariam o nome detonador. 


\subsubsection{Nomes sufixados em $-\operatorname{dor}(a)$}

Este sufixo apresenta semantismos diferenciados dos que são veiculados por -dor. Por isso os produtos em -dor(a) que ostentam essa dissemelhança semântica são tratados à parte dos produtos em -dor. Além da simples mudança masculino/feminino, evidenciada em relação a agentes animados (velejador, velejadora), a forma-dor(a) cumpre outras funções, nomeadamente de caráter semântico. Existem semantismos que são apresentados pelas formas em -dor(a) e que, pelo contrário, são escassamente representados pelos produtos em -dor. Assim, os produtos em -dor(a) aqui mencionados dizem apenas respeito aos lexemas que não apresentam variação masculino/ feminino e que, por isso, têm a forma feminina lexicalizada com semantismo próprio.

A forma da base verbal a que - $\operatorname{dor}(a)$ se anexa é a do tema do presente $($ coser $>$ cosedora $)$.

Quanto às estruturas morfológicas das bases, estas podem ser

(i) bases simples não derivadas (cavar/cavadora, coser/cosedora, fechar/ fechadora);

(ii) bases complexas não derivadas (condensar/condensadora, debulhar/ debulhadora, incubar/incubadora);

(iii) bases simples derivadas (verbos conversos) (fresar/fresadora, granular/ granuladora, metralhar/metralhadora);

(iv) bases complexas derivadas por prefixação (aveludar/aveludadora; desfilar/desfiladora, embobinar/embobinadora, escavar/escavadora).

Dos produtos em - $\operatorname{dor}(a)$ que não correspondem a formas femininas de -dor, ou seja que se apresentam lexicalizadas com semantismo próprio, não constam bases sufixadas nem circunfixadas.

Este sufixo agrega-se a estruturas quer eruditas, quer não eruditas, embora sejam em maior número estas últimas. 
As bases dos produtos nominais em - $\operatorname{dor}(a)$ lexicalizados são de tipo transitivo. São sobretudo verbos causativos (aveludar/aveludadora, condensar/condensadora, desfilar/ desfiladora), indicadores de desempenho (cavar/cavadora, escavar/escavadora, governar/ governadora) e locativos (embobinar/embobinadora, empilhar/ empilhadora), entre outros.

Os produtos em $-\operatorname{dor}(a)$ denotam :

(i) instrumento mecânico (empilhadora, granuladora, escavadora, misturadora) e (ii) agente humano que é uma profissional: aveludadora ('mulher que, nas fábricas têxteis, está encarregada de aveludar os tecidos'), fechadora ('mulher que fecha as caixas ou os pacotes, nas fábricas de tabaco'), cosedora ('mulher que cose velas, seiras de figos'), auscultadora ('religiosa que acompanhava outra ao locutório para ouvir a conversa').

Os restantes produtos em - $\operatorname{dor}(a)$, porque representam o feminino das formas em -dor, não são aqui mencionados.

\subsubsection{Nomes sufixados em - $\operatorname{deir}(\boldsymbol{o})$}

A forma da base verbal a que - $\operatorname{deir}(o)$ se anexa é a do tema do presente (benzer > benzedeiro). O sufixo - deir (o) combina-se preferencialmente com bases de estrutura não erudita.

Quanto à estrutura morfológica das bases verbais, estas são:

(i) bases simples não derivadas (bramar/bramadeiro, tragar/tragadeiro, vindimar/ vindimadeiro);

(ii) bases simples derivadas (verbos conversos) (fiar/fiadeiro, maçar/maçadeiro, malhar/malhadeiro);

(iii) bases complexas não derivadas (traduzir/traduzideiro, transpirar/transpiradeiro); (iv) bases complexas derivadas por prefixação (apear/apeadeiro, arribar/arribadeiro, atascar/atascadeiro, desfilar/desfiladeiro, despenhar/despenhadeiro). 
Não se encontram bases sufixadas nem circunfixadas.

Sob o ponto de vista sintático-semântico, as bases dos produtos em -deir(o) são sobretudo transitivas. Também existem bases inergativas e escassas bases inacusativas. As bases transitivas são indicadoras de desempenho (comer/comedeiro, mandar/mandadeiro), causativas (cremar/cremadeiro, lavar/lavadeiro, picar/ picadeiro), de mover objeto em direção específica (apear/apeadeiro, despenhar/despenhadeiro, esbarrondar/esbarrondadeiro) e locativas (atascar/atascadeiro, atolar/atoladeiro, pousar/pousadeiro). As bases inergativas são de modo de moção (desfilar/desfiladeiro, deslizar/deslizadeiro, resvalar/resvaladeiro), de emissão de som (palrar/palradeiro, piar/piadeiro, bramar/bramadeiro), de emissão de substância (mijar/mijadeiro, transpirar/transpiradeiro), entre outros. As bases inacusativas são de mover-se em direção específica (arribar/arribadeiro, cair/caideiro) e de estado/existência (parar/paradeiro).

O semantismo de -deir(o) é 'que tem a funcionalidade de'. Por este motivo, os agentes humanos são indivíduos que têm a capacidade de efectuar o evento e de o fazer com frequência, como se observa também em produtos adjetivais como namoradeira/o (cf. cap. 3: 3.3.2). Os nomes denotam:

(i) agente humano que é um profissional (cevadeiro, fiadeiro, vindimadeiro); (ii) agente humano que é marcado por uma funcionalidade que ativa frequentemente (benzedeiro, rezadeiro, traduzideiro).

(iii) locativo instigador de evento (atascadeiro, atoladeiro, despenhadeiro); (iv) locativo (apeadeiro, bramadeiro 'lugar de reunião dos veados com cio', cremadeiro, malhadeiro, paradeiro);

(v) recipiente/contentor instigador do evento (assadeiro, cremadeiro 'pira', cevadeiro);

(vi) parte de corpo (tragadeiro '(pop.) goelas; (fig). voragem', transpiradeiro 'poro'); 
(vii) animal (piadeiro 'ave', lavadeiro 'ratinho da América que lava o alimento antes de o comer' (DLP));

(viii) instrumentos (escassos) não mecânicos (moscadeiro 'enxota-moscas', arribadeiro 'cabo que se ala do mar para a terra depois de lançada a rede de arrastar').

\subsubsection{Nomes sufixados em -deir(a)}

A forma da base verbal a que - $\operatorname{deir}(a)$ se anexa é a do tema do presente (tecer $>$ tecedeira).

O sufixo - $\operatorname{deir}(a)$ anexa-se a bases verbais de estrutura não erudita e das seguintes classes morfológicas:

(i) bases simples não derivadas (bater/batedeira, beber/bebedeira, lançar/ lançadeira, lavar/lavadeira);

(ii) bases complexas derivadas por prefixação (amassar/amassadeira, amolar/amoladeira, descascar/descascadeira, encartar/encartadeira, encerar/ enceradeira, escoar/escoadeira, espalhar/espalhadeira) e por sufixação (bastear/basteadeira, escarnicar/escarnicadeira, raspinhar/raspinhadeira, topejar/topejadeira);

(iii) bases simples derivadas (verbos conversos) (espumar/espumadeira, estrelar/estreladeira, feltrar/feltradeira, fritar/fritadeira);

(iv) bases complexas não derivadas (conversar/conversadeira, debulhar/ debulhadeira).

Quanto aos tipos sintático-semânticos das bases, o sufixo agrega-se sobretudo a bases transitivas. As bases inergativas e as inacusativas são escassas. As bases transitivas são causativas (aguçar/aguçadeira, cerzir/cerzideira, cozer/cozedeira), indicadoras de desempenho (governar/governadeira, mamar/mamadeira, escrever/escrevedeira), ornativas 'prover de' (enxofrar/enxofradeira, salgar/salgadeira, 
sulfatar/sulfatadeira), locativas (enfardar/enfardadeira, enformar/ enformadeira, engarrafar/engarrafadeira). As bases inergativas são especialmente de emissão de som (ganir/ganideira, gritar/gritadeira, grunhir/grunbideira), de modo de moção (arruar/arruadeira, engatar/engatadeira), de emissão de substância (cuspir/cuspideira, escarrar/escarradeira, pingar/pingadeira). As bases inacusativas denotam mover-se em direção específica (arribar/arribadeira, descer/descedeira, subir/subideira) e mover-se (passar/passadeira).

São muito variados os semantismos dos nomes deverbais em -deir $(a)$ :

(i) agente humano, mais especificamente uma profissional (bordadeira, assedadeira, brunideira, cerzideira, entre outros), ou alguém avaliado por frequentemente efetuar o evento designado pela base (conversadeira, faladeira, rezadeira). As profissões referem-se sobretudo aos têxteis tradicionais, atividades domésticas e agrícolas;

(ii) instrumento não mecânico de caráter tradicional: bulideira ('pá com que se separam os pães no forno'), zinideira ('pedaço de verga espalmada, preso por um fio a um pau que os rapazes agitam para o fazerem zunir'), apeadeira ('poial ou escadinha que serve de degrau a quem monta ou desce do cavalo'); (iii) instrumento mecânico: encarretadeira ('maquinismo das fábricas de fiação'), enroladeira ('maquinismo que enrola os tecidos nas fábricas de tecelagem'), retorcedeira ('máquina de torcer dois ou mais fios');

(iv) animal: aves como lavadeira ('alvéola'), cantadeira ('cotovia') e escrevedeira;

(v) recipientes/contentores instigadores de evento: geladeira, guisadeira, secadeira, chocadeira;

(vi) recipientes/contentores: tendedeira, amassadeira, salgadeira;

(vi) locativos: conversadeira ('banco de pedra junto a janela; cadeira dupla com assentos opostos');

(viii) vegetal: dormideira 'planta herbácea, lactescente, da família das Papaveráceas, espontânea em Portugal, que tem propriedades sedativas e narcóticas, e da qual se extrai ópio'; mijadeira 'hipericão'. 


\subsubsection{Nomes sufixados em $-\operatorname{dour}(o)$}

O sufixo - $\operatorname{dour}(o)$ anexa-se ao tema do presente da base verbal (comer > comedouro). O valor semântico do sufixo é [propício a/ próprio para].

As bases verbais, preferencialmente de estrutura não erudita, a que o sufixo se anexa são, quanto à sua estrutura morfológica, dos seguintes tipos:

(i) bases simples não derivadas (mirar/miradouro, moer/moedouro, piar/piadouro, sorver/sorvedouro);

(ii) bases complexas derivadas por prefixacão (amassar/amassadouro, desovar/ desovadouro, embarcar/embarcadouro, espreguiçar/espreguiçadouro, resfriar/ resfriadouro), por sufixação (fundear/fundeadouro, passear/passeadouro) e por circunfixação (abastecer/abastecedouro, espojar/espojadouro);

(iii) bases simples derivadas (verbos conversos), como ancorar/ancoradouro, babar/babadouro, grudar/grudadouro, secar/secadouro;

(iv) bases complexas não derivadas (absorver/absorvedouro, respirar/respiradouro).

Quanto aos tipos sintático-semânticos das bases com que se combina, estas são, na sua maioria, transitivas, mas também existem bases inacusativas e inergativas. As bases transitivas são sobretudo indicadoras de desempenho (beber/bebedouro, comer/comedouro, calcar/calcadouro), causativas (lavar/lavadouro, enxugar/enxugadouro, puir/puidouro), ornativas 'prover de' (chumbar /chumbadouro), entre outras. As bases inacusativas são de estado/existência (parar/ paradouro, pousar/pousadouro), incoativas (coalhar/coalhadouro, germinar/germinadouro), aparecimento (assomar/assomadouro, nascer/nascedouro, surgir/surgidouro). As bases inergativas são de modo de moção (correr/corredouro, passear/passeadouro), de emissão de som (piar/piadouro, chiar/chiadouro), de emissão de substância (suar/suadouro, cuspir/cuspidouro). 
Quanto às suas significações, os nomes sufixados em -dour(o) denotam:

(i) locativo instigador do evento (escorregadouro, corredouro);

(ii) locativo (bailadouro, pastadouro, espolinhadouro);

(iii) instrumento não mecânico (esborralhadouro, assucadouro);

(iv) parte do corpo: pousadouro, cilhadouro ('sítio do corpo das bestas onde se aperta a cilha'), pegadouro ('parte por onde se pega num objeto');

(v) recipiente/contentor (bebedouro, comedouro).

Não se encontraram nomes portadores deste sufixo que designem agente humano ou animal, ou seja, que apresentem agentes 'controladores do evento'.

O sufixo -dour (o) não corresponde univocamente nem a argumento da base verbal, nem a uma função sintática. Há produtos que correspondem a argumentos internos-sujeito (fervedouro), a argumentos internos-objeto (embarcadouro) e a argumentos externos (ruminadouro).

A comparação dos nomes sufixados em -dor, -deir(o) e -dour(o) permite observar que os derivados em -dor são os mais vocacionados para o semantismo de 'instigador de evento', assim se explicando que denotem muitos agentes humanos e animais. Nos produtos em -dour (o), o indivíduo designado encontra-se relacionado com o evento, por ser a este propício. Mas, ao contrário de -dor, não é instigador desse evento, apenas propício à sua ocorrência. Este dado justifica a ausência de agente humano e animal, bem como de instrumentos mecânicos. Quanto a -deir(o), este encontra-se num nível intermédio entre os outros dois sufixos.

\subsubsection{Nomes sufixados em $-\operatorname{dour}(a)$}

O sufixo-dour(a) anexa-se ao tema do presente da base verbal (varrer > varredoura) e acopla-se preferencialmente a bases de estrutura não erudita. 
O sufixo combina-se com bases verbais com as seguintes estruturas morfológicas: (i) bases simples não derivadas (cantar/ cantadoura, correr/corredoura, dobar/dobadoura, lavar/lavadoura, levar/levadoura); e (ii) bases complexas derivadas por prefixação (espalhar/espalhadoura, respigar/respigadoura). Não se encontraram bases formadas por sufixação, por circunfixação, nem bases simples derivadas (verbos conversos) ou bases complexas não derivadas.

Quanto aos tipos sintático-semânticos das bases, estas são, na sua maioria, transitivas, mas também existem bases inergativas. Não se encontraram bases inacusativas. As bases transitivas são sobretudo causativas com uso de instrumento (aguçar/aguçadoura, torcer/ torcedoura, varrer/varredoura), mover através de força (puxar/ puxadoura, tirar/tiradoura) e mover objeto sem alteração espacial (torcer/torcedoura, tornar/tornadoura). As bases inergativas são verbos de emissão de som (cantar/cantadoura) e de modo de moção (correr/corredoura).

Os nomes denotam: instrumento não mecânico (aguçadoura, rapadoura, roçadoura, levadoura, tangedoura, tapadoura); recipiente/contentor (manjedoura); locativo (corredoura); evento (varredoura 'grande morticínio ou destruição').

Estão ausentes agentes humanos e animais, bem como instrumentos mecânicos. Comparativamente com os derivados em -dour(o), que são maioritariamente locativos, nos nomes em -dour(a) predominam as significações de instrumento. O sufixo - $\operatorname{dour}(a)$ não corresponde univocamente nem a argumento da base verbal, nem a uma função sintática objeto, como acontece com o seu congénere masculino.

\subsubsection{Nomes sufixados em $-n t(e)$}

O sufixo $-n t(e)$ anexa-se ao tema do presente da base verbal (reger > regente). 
O sufixo combina-se com bases verbais preferencialmente não eruditas que, quanto às suas estruturas morfológicas, são dos seguintes tipos:

(i) bases simples não derivadas (lançar/lançante, laxar/laxante, ler/lente);

(ii) bases complexas não derivadas (pretender/pretendente, absorver/ absorvente, imigrar/imigrante);

(iii) bases simples derivadas (verbos conversos) (feirar/feirante, oxidar/ oxidante, parodiar/parodiante);

(iv) bases complexas derivadas por sufixação (esterilizar/ esterilizante, fertilizar/fertilizante, fortificar/fortificante, passear/passeante, veranear/ veraneante) e por prefixação (adoçar/adoçante, assaltar/assaltante, descoagular/descoagulante, descolorar/descolorante, desinfetar/desinfetante).

Não se encontraram bases formadas por circunfixação.

No que diz respeito aos tipos sintático-semânticos das bases, estas são maioritariamente transitivas, seguindo-se as bases inacusativas e, por último, as inergativas. Das bases transitivas destacam-se as indicadoras de desempenho (manifestar/manifestante, mercar/mercante, ministrar/ ministrante, negociar/negociante), as causativas (corar/corante, descoagular/descoagulante, descolorar/descolorante, desinfectar/desinfectante, despolarizar/ despolarizante) e as declarativas e de atos de fala (anunciar/anunciante, apelar/ apelante, arguir/arguente, argumentar/ argumentante). Nas bases inacusativas encontram-se, por exemplo, verbos de existência/estado (circunstar/circunstante, constar/constante), de mover-se em direção específica (chegar/chegante, retroceder/ retrocedente, descer/ descente), verbos incoativos (convalescer/convalescente, crescer/ crescente), de aparecimento (incidir/incidente, nascer/nascente), etc. Nas bases inergativas encontram-se indicadoras de desempenho (militar/militante, oficiar/oficiante), de modo de moção (navegar/ navegante, viajar/viajante, viandar/viandante), de emissão de som 
(chiar/chiante, estridular/estridulante), de emissão de luz (brilhar/ brilhante, fulminar/fulminante) e de emissão de substância (espumar/espumante).

O semantismo deste sufixo é [que tem a propriedade de]. Com este traço, o sufixo formata indivíduos denotadores de uma propriedade intrínseca que lhes possibilita a sua relação com o evento, sem serem dele controladores. A isto se deve o grande número de produtos que designam substâncias e a escassez de produtos designadores de instrumentos. Aliás, não se encontrou nenhum nome de instrumento mecânico. É também devido a este traço que nas bases destes produtos existe maior número de verbos inacusativos do que nas bases dos produtos em -dor, por exemplo.

Os nomes em -nte denotam

(i) agente humano (debutante, presidente, veraneante). Dentro deste conjunto destacam-se os grupos sociais organizados, como os seguidores de correntes religiosas (os protestantes, os flagelantes 'membros de uma seita religiosa do séc. XIII que se flagelavam em público');

(ii) substâncias: adoçante, corante, desmaquilhante, reagente, solvente. Neste domínio este sufixo é muito usado no tecnoléxico da Química, pelo facto de as substâncias serem evidenciadas por uma propriedade inerente (coagulante, reagente, comburente);

(iii) experienciador (amante, crente, padecente);

(iv) animal (ruminante, reptante, estridulante, amarelante 'ave');

(v) locativo (vazante, vertente);

(vi) locativo instigador do evento (escoante, lançante, restaurante);

(vii) instrumento não mecânico (tirante e trinchante).

É possível que, com a evolução da língua, e com a lexicalização de alguns nomes, se esbata a diferenciação semântica expectável entre produtos corradicais em $-n t(e)$ [que tem a propriedade de] e 
em -dor [que tem a função de], como lavrante e lavrador, negociante e negociador, amante e amador, gerante e gerador. Nestes casos, nem todos os nomes em - nt (e) denotam [que tem a propriedade de] e nem todos em -dor [que tem a função de], como se verifica em amante e amador, negociante e negociador, pois amador denota 'não profissional' e negociador 'aquele que trata de uma negociação' e negociante 'pessoa que negoceia; comerciante'.

O sufixo não coincide com um argumento da base verbal. Pode ter relação com um argumento externo (gerente) ou com um argumento interno (imigrante). O que há em comum entre os elementos com que o sufixo se correlaciona é que esse elemento corresponde àquele que tem propriedade intrínseca designada pela base. Trata-se do elemento da estrutura léxico-semântica com maior proeminência na hierarquia temática.

\subsubsection{Nomes sufixados em -vel}

Comparativamente com os adjetivos, são escassos os nomes formados com -vel. O sufixo anexa-se ao tema do pretérito. Na ausência de um nome formado a partir de um verbo da $2 .^{a}$ conjugação, recorre-se a um adjetivo (bebivel).

Para formar nomes, o sufixo, cujo traço semântico é [possível de], anexa-se a bases verbais que apresentam as seguintes estruturas morfológicas:

(i) bases complexas não derivadas (consumir/consumível, dirigir/dirigível, submergir/submergível);

(ii) bases simples não derivadas (miserar/miserável, variar/variável).

O facto de se encontrarem somente estas bases não significa que os restantes tipos estejam interditos à formação de nomes, uma vez 
que estão disponíveis para a geração de adjetivos com o mesmo sufixo (cf. cap. 3: 3.3.16).

Quanto aos tipos sintático-semânticos das bases, só se encontram atestados nomes formados a partir de bases transitivas. Estas indicam moção de objeto (dirigir/dirigível), moção de objeto em direção específica (submergir/submergível), causativas (consumir) consumível) e de experienciador-sujeito (miserar/miserável).

Quanto aos semantismos destes produtos, os exemplos encontrados mostram que o sufixo se correlaciona com o elemento da estrutura léxico-semântica da base menos proeminente na hierarquia temática. Os nomes denotam: (i) instrumento mecânico (dirigível, submergível); (ii) objeto genérico (consumível, variável); (iii) objeto humano/animado (miserável).

\subsubsection{Nomes sufixados em -al}

O sufixo - al forma escassos produtos nominais com base em verbos. Anexa-se ao radical da base (estender > estendal) e as estruturas morfológicas das bases compreendem os seguintes tipos:

(i) bases simples não derivadas (passar/passal, tender/tendal);

(ii) bases simples derivadas (verbos conversos) (firmar/firmal 'espécie de broche com que se prendiam os vestidos');

(iii) bases complexas derivadas por prefixação (estender/estendal).

Quanto aos tipos sintático-semânticos das bases, o sufixo anexa-se a verbos transitivos e inergativos. Os verbos transitivos podem ser causativos (firmar/firmal), de moção de objeto (passar/passal) e de configuração espacial (tender/tendal, estender/ estendal). Nos verbos inergativos encontram-se bases de moção (tremer/tremedal). 
O semantismo aportado pelo sufixo aos produtos é sintetizável por [relativo a/próprio de]. Os nomes deverbais denotam: locativo (estendal, passal 'propriedade agrícola anexa à igreja ou residência paroquial para rendimento do pároco'), tendal ('(engenhos de açúcar) lugar onde se assentam as formas'); locativo instigador de evento (tremedal 'campo lamacento'); parte de corpo (firmal 'pontas do cabresto'); evento (estendal 'alarde; ostentação; exposição de coisas; explanação fastidiosa'). Também 'objeto onde se estende roupa' (estendal).

\subsubsection{Nomes sufixados em - $\tilde{a} o$}

O sufixo anexa-se ao radical da base (lamber > lambão).

Quando o sufixo forma nomes de indivíduo, as estruturas morfológicas das bases são preferentemente não eruditas e dos seguintes tipos:

(i) bases simples não derivadas: pingar/pingão, mergulhar/mergulhão, queimar/ queimão;

(ii) bases simples derivadas (verbos conversos): babar/babão, badalar/badalão, feirar/feirão;

(iii) bases complexas derivadas por prefixação (esgarrar/esgarrão, desgarrar/ desgarrão, refilar/refilão, remexer/remexão, repontar/repontão) e por sufixação (carrejar/carrejão, corricar/corricão, guerrear/guerreão, pedinchar/pedinchão); (iv) bases complexas não derivadas (demandar/demandão, resmungar/resmungão).

Não se encontram bases circunfixadas para estes produtos.

Quando forma produtos de indivíduo, o sufixo -ão opta por bases transitivas e inergativas. Nas transitivas encontram-se verbos indicadores de desempenho (beberrar/beberrão, chuchar/chuchão), causativos (picar/picão, pisar/pisão, queimar/queimão), declarativos e atos de fala (gabar/gabão, perguntar/perguntão, responder/res- 
pondão, rezar/rezão), de perceção (espiar/espião, mirar/mirão), de pedir (demandar/demandão, pedinchar/pedinchão), entre outros. Nas bases inergativas encontram-se verbos de emissão de som (berrar/ berrão, chiar/chião, chorar/chorão), de desempenho (mandriar/ mandrião, marrar/marrão, turrar/turrão), de modo de moção (corricar/corricão, gingar/gingão, mancar/mancão), declarativos e atos de fala (palrar/palrão, ralhar/ralhão, refilar/refilão). Não se encontraram verbos inacusativos como bases destes produtos.

Os nomes denotam:

(i) agente humano (bailão, berrão, chorão, fungão, palrão, ralhão, refilão)

e, por vezes, profissional (feirão, ceifão, remendão);

(ii) animal: saltão (espécie de insecto 'gafanhoto'), tremão (espécie ictiológica 'tremelga'), chião, chorão (denominações populares de espécies de ave e peixe), rinchão, corricão e mancão (aves);

(iii) vegetal (chorão, mamão, queimão);

(iv) instrumento não mecânico (calcão, esfregão, picão, podão, segão, trinchão) e instrumento mecânico (carretão, pisão).

O indivíduo é avaliativamente individualizado pela frequência e intensidade com que efetua um evento. Esse evento é de caráter comezinho, concreto e doméstico. Estão excluídas destas bases verbos inacusativos e verbos que indiquem evento efetuado através de força impulsiva. Estas condições servem para a formação de produtos em -ão de evento (cf. cap. 2: 2.4.1.7).

\subsubsection{Nomes sufixados em -tóri(o)}

Além de servir a formação de nomes de 'evento' (2.4.1.15), o sufixo -tóri(o) opera também na construção de adjetivos e na de nomes de 'indivíduo'. 
$\mathrm{Na}$ formação de nomes de 'indivíduo', este sufixo anexa-se a bases complexas não derivadas (transpirar/transpiratório), mas também a bases simples não derivadas (orar/oratório, sanar/ sanatório), a bases simples derivadas (blasfemar/blasfematório) e a bases complexas derivadas por sufixação (purificar/purificatório). As bases complexas não derivadas encontram-se sobretudo nos produtos que designam indivíduo. Saliente-se que este facto se prende com a significação de teor técnico que muitos destes produtos apresentam, pois muitos verbos de estrutura complexa não derivada funcionam em tecnoléxicos.

Quanto aos tipos sintático-semânticos das bases verbais, estes são: (i) inergativos de desempenho (dormir/dormitório, libar/libatório), de atos de fala (orar/oratório), de emissão de substância (defecar) defecatório, exsudar/exsudatório); (ii) transitivos causativos (conservar/conservatório, cremar/crematório, escorificar/escorificatório, lavar/lavatório, purgar/purgatório, purificar/purificatório) e de configuração espacial (reclinar/reclinatório).

Os produtos nominais de indivíduo designam locativo 'onde se V' (dormitório, oratório, parlatório) e locativo instigador do evento 'local para V' (purgatório, sanatório), recipiente/contentor (escorificatório 'vaso de escorificar metais', libatório 'vaso para libações', reclinatório 'aquilo que serve para alguém se reclinar') e instigador do evento (purificatório, separatório), substância (exsudatório, transpiratório), agente humano (escasso) (famulatório).

As significações de indivíduo localizam-se em domínios referenciais específicos (cf. conservatório [de estudo artístico], crematório, escorificatório 'vaso de escorificar metais', invitatório 'antífona no princípio das matinas', libatório 'vaso para libações', transpiratório 'sudorífero'), funcionando como nomes especializados. Ao contrário do que ocorre nos produtos de evento deste sufixo, os de indivíduo não são caraterizados por traços semânticos avaliativos. 


\subsubsection{Nomes sufixados em -óri(o)}

Historicamente, -óri(o) e -tóri(o) representam variantes do mesmo sufixo em latim, dependendo da formatação da base - o terceiro radical - a que se agregava (Nunes ([1919] 1989: 371); Said Ali (1964: 238); Diez (1874: 327-328); Meyer-Lübke (1895: 579-583); Pensado (1999: 4487)). No entanto, as duas formas apresentam-se ativas em português, razão por que se consideram os dois sufixos como independentes.

$\mathrm{Na}$ produção de nomes, o sufixo -óri(o) prefere bases com as seguintes estruturas morfológicas: bases complexas não derivadas (consultar/consultório, dejectar/dejectório); bases complexas derivadas por prefixação (desinfectar/desinfectório); e bases simples não derivadas (velar/velório, casar/casório).

Quanto aos tipos sintático-semânticos, as bases são verbos transitivos de desempenho (consulta/consultório, casar/casório, velar/ velório) e causativos (desinfectar/desinfectório).

Os semantismos dos produtos são locativo (consultório, desinfectório, velório), recipiente/contentor (dejectório) e evento (casório).

$\mathrm{Na}$ formação isocategorial (cf. cap. 5), o sufixo mostra maior produtividade (alegrório, escadório, estudantório, finório, farelório, foguetório, etc.).

\subsubsection{Nomes sufixados em -tóri(a)}

Quanto à suas estrutura morfológica, as bases são bases complexas não derivadas (convocar/convocatória, declinar/declinatória, dedicar/dedicatória) e bases simples não derivadas (jacular/jaculatória, orar/oratória, oscilar/oscilatória). Apenas foram encontradas bases não construídas. O sufixo, muito usado na linguagem jurídica e eclesiástica, prefere bases com estruturas eruditas. 
Sob o ponto de vista sintático-semântico, as bases são temas de verbos (i) transitivos, sobretudo declarativos e indicadores de atos de fala (dedicar/dedicatória, objurgar/objurgatória, revocar/revocatória) e de pedir (invocar/invocatória, rogar/rogatória), causativos (eliminar/eliminatória, revogar/revogatória); (ii) inacusativos de mover-se em direção específica (declinar/ declinatória, escapar/escapatória); (iii) inergativos de modo de moção (oscilar/oscilatória) e atos de fala (orar/oratória).

Os nomes denotam:

(i) causa (convocatória, declinatória, eliminatória, recordatória, inibitória),

(ii) locativo instigador de evento (conservatória),

(iii) locativo (escapatória 'zona alargada numa pista de corridas de automóvel para evitar acidentes em casos de despiste'),

(iv) arte/técnica (oratória, rogatória),

(v) vegetal (oscilatória 'planta microscópica, cianófita, da fam. das Oscilatoriáceas (género Oscillatoria), que apresenta movimentos caraterísticos, também denominada oscilária'),

(vi) instrumento não mecânico (declinatória 'instrumento semelhante à bússola, empregado nos levantamentos topográficos').

\subsubsection{Nomes sufixados em -eir(o)}

O sufixo -eir(o) seleciona o radical verbal (caminhar >caminheiro) e combina-se preferencialmente com bases não eruditas, das quais se salientam as sufixadas com avaliativos.

As estruturas morfológicas das bases verbais são as seguintes:

(i) bases simples não derivadas (guiar/guieiro, lograr/logreiro, nascer/ nasceiro, palrar/palreiro);

(ii) bases simples derivadas (verbos conversos) (chocar/choqueiro, decilitrar/ decilitreiro, faiscar/faisqueiro, gadanhar/ gadanheiro); 
(iii) bases complexas não derivadas (escassas): trafegar/trafegueiro;

(iv) bases complexas derivadas por sufixação avaliativa, que são dominantes (chapinhar/chapinheiro, choramingar/choramingueiro, fervilhar/fervilheiro, golelhar/golelheiro, lambiscar/lambisqueiro, patinhar/patinheiro, pedinchar/ pedincheiro), por prefixação (atascar/ atasqueiro, empreitar/empreiteiro, encomendar/encomendeiro, entornar/entorneiro, esgotar/esgoteiro, espreguiçar/espreguiceiro, rebuscar/rebusqueiro, recovar/recoveiro, remendar/ remendeiro) e por escassa sufixação não avaliativa (granjear/granjeeiro, negacear/negaceiro).

Não se encontram bases circunfixdas.

Quanto aos tipos sintático-semânticos, as bases podem ser: (i) transitivas, e estas são sobretudo causativas (ceifar/ceifeiro, chocar/ choqueiro, remendar/remendeiro, rilhar/rilheiro), performativas (alcovitar/alcoviteiro, aldrabar/aldrabeiro, baldrocar/baldroqueiro, beijocar/beijoqueiro); (ii) inergativas de emissão de som/ato de fala (bisbilhotar/ bisbilhoteiro, coscuvilhar/coscuvilheiro, golelhar/golelheiro, palrar/palreiro, rezingar/rezingueiro, taramelar/tarameleiro), de emissão de substância (gear/geeiro, chapinhar/chapinheiro), de emissão de luz (faiscar/faisqueiro), de modo de moção (andar/ andadeiro, caminhar/caminheiro, patinhar/patinheiro); (iii) raras bases inacusativas de aparecimento (nascer/nasceiro) e de mover-se em direção específica (pousar/pouseiro).

O sufixo atribui aos produtos um semantismo de 'frequente'. Estes denotam:

(i) agente humano: alanzoeiro, andeiro, badaleiro, bisbilhoteiro. Pode ser profissional: albergueiro, ceifeiro, calceteiro, capineiro, gadanheiro;

(ii) locativo instigador do evento: atasqueiro, atoleiro, chapinheiro, patinheiro; (iii) locativo: choqueiro 'sítio onde a galinha choca os ovos', espojeiro, geeiro 'lugar onde geralmente se forma geada', rilheiro 'lugar onde os ratos juntam e rilham o que furtam; celeiro'; 
(iv) recipiente/contentor: esgoteiro 'reservatório de água junto de cada compartimento cristalizador, nas salinas'; trafegueiro 'pequeno barco';

(v) instrumento não mecânico: tempereiro 'peça do tear que se fixa às ourelas do pano para que ele não encolha; cada um dos paus fixos à nora, na direção do eixo'.

\subsubsection{Nomes sufixados em -eir(a)}

O sufixo anexa-se ao radical (costurar $>$ costureira) e as bases podem ser, no que à sua estrutura morfológica, diz respeito:

(i) bases simples não derivadas (coalhar/coalheira);

(ii) bases simples derivadas (verbos conversos) (cirandar/cirandeira, enxofrar/enxofreira, gadanhar/gadanheira);

(iii) bases complexas derivadas por sufixação avaliativa (cuspinhar/ cuspinheira, mexericar/mexeriqueira) e por prefixação (encabar/encabeira).

(iv) Não estão atestadas bases circunfixadas nem bases complexas não construídas.

(v) O sufixo opta por estruturas não eruditas.

Quanto aos tipos sintático-semânticos, as bases são: inergativas de desempenho (cirandar, mexericar, piscar), de emissão de substância (bafar, cuspinhar) e de modo de moção (trepar); e transitivas de desempenho (espetar, gadanhar, rapar, regatar), causativas (abafar, cansar, coalhar, torrar), ornativas (enxofrar), locativas (encabar). Não se encontraram bases inacusativas.

Os semantismos dos produtos são:

(i) agente humano (bufeira, cirandeira, mexeriqueira; também profissional: costureira, cozinheira, escabicheira 'mulher que apanha as algas que o mar arroja à praia');

(ii) animal (trepeira 'ave (trepadeira)') 
(iii) instrumento não mecânico (bafareira 'parte superior da serpentina de alguns alambiques'; espeteira 'gancho, nos armários, para pendurar carne, vasilhas, etc.'); instrumento mecânico (gadanheira);

(iv) locativo (enxofreira 'lugar de onde se extrai enxofre; vulcão que expele gases sulfurosos');

(v) parte do corpo (coalheira 'última cavidade do estômago dos ruminantes').

\subsubsection{Nomes sufixados em -(t)ári(o)}

O sufixo -tári(o) anexa-se a bases de tema em - $a$-, combinando-se com o radical (pactuar > pactuário, arrendar > arrendatário). Se fizesse parte do tema, o segmento /a/ não seria acentuado.

O sufixo - $(t) a ́ r i(o)$ opta pelos seguintes tipos de estruturas morfológicas de bases:

(i) bases simples derivadas (verbos conversos) (alvorar/alvorário);

(ii) bases complexas não derivadas (adjudicar/adjudicatário, dispensar/dispensário);

(iii) bases complexas derivadas por prefixação (arrendar/arrendatário);

(iv) bases simples não derivadas (enxertar/enxertário).

Quanto aos tipos sintático-semânticos, as bases são sobretudo verbos transitivos de desempenho.

Os produtos denotam agente humano (arrendatário, adjudicatário, alvorário 'doidivanas') e instrumento não mecânico (enxertário 'reunião dos cabos que atracam a verga ao mastro').

\subsubsection{Nomes sufixados em -ilh(o) e em -ilh(a)}

Estes sufixos anexam-se ao radical (amassar > amassilho, cortar $>$ cortilha) e combinam-se com bases com as seguintes estruturas 
morfológicas: bases simples não derivadas (atar/atilho, cortar/ cortilha, pagar/paguilha, trocar/troquilha, pegar/peguilho, rapar/ rapilho, raspar/raspilha) e bases complexas derivadas por prefixação (amassar/amassilho, recortar/recortilha). Os sufixos preferem bases não eruditas. Quanto aos tipos sintático-semânticos das bases, estas são transitivas de desempenho e causativas.

Os produtos denotam: agente humano (paguilha 'pagador', troquilha 'pessoa que negoceia por meio de trocas'); instrumento não mecânico (amassilho, atilho, cortilha, raspilha, recortilha); porção (amassilho 'porção de farinha que se amassa de cada vez'); locativo (esconderilho); causa genérica (peguilho 'aquilo que pega, cola, prende ou estorva'); vegetal (rapilho, mondilho).

\subsubsection{Nomes sufixados em -alh(o), -alh(a), -elh(o) e -ulb(o)}

O sufixo -alh (o) anexa-se ao radical da base (escorrer $>$ escorralho) e combina-se com bases morfologicamente simples não derivadas (escarvar/escarvalho, esfregar/esfregalho, espantar/ espantalho, pregar/pregalho) e com bases complexas derivadas por prefixação (escorrer/escorralho, remoer/remoalho, revirar/reviralho). O sufixo opta por bases não eruditas que, quanto aos tipos sintático-semânticos, são transitivas de desempenho e causativas.

Os nomes sufixados denotam: instrumento não mecânico (esfregalho, espantalho, pregalho 'cabo que serve de adriça aos toldos das embarcações'); parte de um corpo que é um resultado concreto (escarvalho 'cavidade que surge na parte interna dos canhões'); restos (escorralho, rebotalho 'o que fica depois de escolhido o melhor'); resultado concreto (remoalho 'bolo alimentício que os ruminantes fazem vir do estômago à boca para o remoerem'); evento (reviralho).

Com o sufixo - $\operatorname{alh}(a)$ apenas se atestam os nomes acendalha e aralha 'novilha de dois anos que já pode arar'. Os sufixos -elh(o) 
e -ulh(o) só foram encontrados nos nomes rapelho 'bicha-cadela' e tapulho 'peça com que se tapa'.

\subsubsection{Nomes sufixados em $-\operatorname{et}(a)$}

O sufixo anexa-se ao radical (chupar $>$ chupeta).

Quanto à estrutura morfológica das bases, estas são simples não derivadas: cheirar/cheireta, chilrar/chilreta, chupar/chupeta, escalfar/escalfeta, forrar/forreta, gorgolar/gorgoleta. O sufixo opta, pois, por bases de estruturas não eruditas. Os tipos sintático-semânticos das bases são (i) transitivos de desempenho, de perceção; (ii) inergativos de emissão de som.

Os produtos denotam:

(i) agente humano (cheireta, forreta);

(ii) ave (chilreta 'churreca (ave palmípede)')

(iii) instrumento não mecânico (chupeta, escalfeta, picareta, tapeta);

(iv) recipiente/contentor (gorgoleta 'bilha de barro com gargalo de ralo por onde a água, ao passar, produz ruído').

\subsubsection{Nomes sufixados em -tiv(o), -tiv(a) e -iv(o)}

Os sufixos -tiv(o) e -tiv(a) anexam-se ao tema das bases (depurar $>$ depurativo, estimar > estimativa) e combinam-se com bases preferencialmente de estrutura erudita e dos seguintes tipos morfológicos:

(i) bases complexas não derivadas (apelar/apelativo, comparar/ comparativo, confortar/confortativo, depurar/depurativo, derivar/derivativo, estimar/estimativa) e (ii) bases simples não derivadas (curar/ curativo, estar/estativo, fugir/fugitivo, tentar/tentativa). 
O sufixo - $t i v(a)$ carateriza-se pelas mesmas seleções que -tiv(o).

Quanto aos tipos sintático-semânticos das bases, estes são: (i) transitivos, sobretudo causativos (lenir/lenitivo, paliar/paliativo, refrigerar/refrigerativo); (ii) inacusativos (fugir/fugitivo, supurar/supurativo, estar/estativo). Não foram encontradas bases inergativas.

Os semantismos dos nomes em -tiv(o) são caraterizados por denotarem entidades com a [propriedade de]:

(i) substância (confortativo, espoliativo, lenitivo, paliativo, sedativo);

(ii) categoria gramatical (apelativo, aumentativo, comparativo);

(iii) agente/experienciador humano (contemplativo, fugitivo);

(iv) causa genérica (derivativo, preservativo);

(v) parte de corpo/instrumento (estativo 'parte mecânica de alguns aparelhos, como o microscópio').

Os semantismos dos nomes em -tiv(a) são: proposição, produto linguístico/conceptual (afirmativa, estimativa, intimativa, justificativa, narrativa, rogativa); faculdade/capacidade (contemplativa, especulativa, imaginativa); agente coletivo (cooperativa); evento (alternativa, classificativa, expectativa, iniciativa, tentativa).

No que diz respeito aos nomes em -iv(o), apenas foram encontrados os nomes abrasivo, abortivo, vomitivo e processivo.

Como observável por alguns dos lexemas apresentados, este sufixo opera também na formação adjetival (cf. 3.3.10 e 3.3.11).

\subsubsection{Conspecto geral}

O quadro seguinte expõe a distribuição dos semantismos de 'indivíduo' por operadores sufixais. 


\begin{tabular}{|c|c|c|c|c|c|c|c|c|c|c|c|}
\hline & \multicolumn{11}{|c|}{ significações } \\
\hline $\begin{array}{l}\text { Sufixos for- } \\
\text { madores de } \\
\mathrm{N} \text { deverbais } \\
\text { de 'indivíduo' }\end{array}$ & $\begin{array}{l}\text { Agen- } \\
\text { te } \\
\text { hu- } \\
\text { mano }\end{array}$ & \begin{tabular}{|l} 
Causa \\
não \\
especi- \\
ficada \\
caráter \\
[huma- \\
no]
\end{tabular} & $\begin{array}{l}\text { Subs- } \\
\text { tância }\end{array}$ & $\begin{array}{l}\text { Vege- } \\
\text { tal }\end{array}$ & $\begin{array}{l}\text { Ani- } \\
\text { mal }\end{array}$ & $\begin{array}{l}\text { Instru- } \\
\text { mento } \\
\text { mecani- } \\
\text { zado }\end{array}$ & $\begin{array}{l}\text { Instru- } \\
\text { mento } \\
\text { não me- } \\
\text { canizado }\end{array}$ & $\begin{array}{l}\text { Expe- } \\
\text { rien- } \\
\text { ciador }\end{array}$ & $\begin{array}{l}\text { Loca- } \\
\text { tivo }\end{array}$ & $\begin{array}{l}\text { Parte } \\
\text { de cor- } \\
\text { po ou } \\
\text { instru- } \\
\text { mento }\end{array}$ & $\begin{array}{l}\text { Reci- } \\
\text { piente/ } \\
\text { con- } \\
\text { tentor }\end{array}$ \\
\hline$-n t(e)$ & + & & + & & + & & + & + & + & & \\
\hline$-\operatorname{dor}(a)$ & + & & & & & + & & & & & \\
\hline -dor & + & & + & & + & + & + & + & & + & + \\
\hline$-\operatorname{dour}(o)$ & & & & & & & + & & + & + & + \\
\hline$-\operatorname{dour}(a)$ & 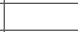 & & & & & & + & & + & & + \\
\hline$-\tilde{a} \boldsymbol{O}$ & + & & & + & + & + & + & & & & \\
\hline$-v e l$ & & & & & & + & & & & & \\
\hline$-\operatorname{deir}(0)$ & + & & & & + & & + & & & + & + \\
\hline$-\operatorname{deir}(a)$ & + & & & + & + & + & + & & + & + & + \\
\hline $\begin{array}{l}\text {-óri(a)/ } \\
\text {-tóri(a) }\end{array}$ & & + & & + & & & + & & + & & \\
\hline $\begin{array}{l}\text {-óri(o)/ } \\
\text {-tóri(o) }\end{array}$ & + & & + & & & & & & + & & + \\
\hline$-a l$ & & & & & & & & & + & + & \\
\hline$-\operatorname{eir}(a)$ & + & & & & + & + & + & & + & + & \\
\hline$-\operatorname{eir}(o)$ & + & & & & & & + & & & & + \\
\hline$-e t(a)$ & + & & & & + & & + & & & & + \\
\hline$-a l b(o)$ & & & & & & & + & & & + & \\
\hline$-a l b(a)$ & & & + & & + & & & & & & \\
\hline$-e l b(o)$ & + & & & & & & & & & & \\
\hline$-i l b(a)$ & + & & & & & & + & & & & \\
\hline$-i l b(o)$ & & + & & + & & & + & & + & & \\
\hline$-u l b(o)$ & & & & & & & + & & & & \\
\hline$-t i v(o) / i v o$ & + & + & + & & & & & + & & + & \\
\hline -tiva/iv(a) & & + & & & & & & & & & \\
\hline $\begin{array}{l}\text {-tário/ } \\
\text {-ári(o) }\end{array}$ & + & & & & & & + & & & & \\
\hline
\end{tabular}

Quadro II.23. Relação entre sufixos formadores de nomes deverbais de indivíduo e suas significações.

A observação do quadro mostra que as significações de indivíduo se encontram repartidas pelas seguintes classes: i) agente humano (arrumador, presidente); ii) agente/causa não especificado quanto ao caráter [+-humano] (derivativo); iii) substâncias (desmaquilhante); iv) vegetais (trepadeira 'planta'); v) animais (saltão 'gafanhoto'); vi) instrumentos mecanizados (metralhadora); vii) instrumentos não mecanizados (assador); viii) experienciador (pensador); ix) locativos (passadeira); $\mathrm{x}$ ) locativos causativos (incubadora); xi) partes de um corpo ou instrumento (cingideira 'o dedo médio, nas aves de rapina') e xii) recipientes/contentores (amassadeira). 
Os dados aqui sintetizados apontam para uma correlação entre os sufixos mais produtivos e a diversidade de significações. Assim, sufixos como -dor ou - nt(e), que são dos mais produtivos do português (cf. Almeida 2009), apresentam grande diversidade de significações, enquanto sufixos como - alh(o) ou -et(a) não dispersam as suas significações por tantos subtipos semânticos.

A distribuição destes sufixos por tipos sintático-semânticos de bases condensa-se no quadro seguinte.

\begin{tabular}{|c|c|c|c|}
\hline & \multicolumn{3}{|c|}{ Tipos de bases } \\
\hline $\begin{array}{l}\text { Sufixos formadores de nomes } \\
\text { deverbais de 'indivíduo' }\end{array}$ & transitivas & inergativas & inacusativas \\
\hline$-n t(e)$ & + & + & + \\
\hline$-\operatorname{dor}(a)$ & + & & \\
\hline$-d o r$ & + & + & + \\
\hline$-\operatorname{dour}(o)$ & + & + & + \\
\hline$-\operatorname{dour}(a)$ & + & + & \\
\hline$-\tilde{a} \boldsymbol{o}$ & + & + & \\
\hline$-v e l$ & + & & \\
\hline$-\operatorname{deir}(o)$ & + & + & + \\
\hline$-\operatorname{deir}(a)$ & + & + & + \\
\hline -óri(a)/tóri(a) & + & + & + \\
\hline -óri(o)/tóri(o) & + & + & \\
\hline$-a l$ & + & + & \\
\hline$-\operatorname{eir}(a)$ & + & + & \\
\hline$-\operatorname{eir}(o)$ & + & + & + \\
\hline$-e t(a)$ & + & + & \\
\hline$-\operatorname{alh}(o)$ & + & & \\
\hline$-\operatorname{alh}(a)$ & + & & \\
\hline$-e l h(o)$ & + & & \\
\hline$-i l b(a)$ & + & & \\
\hline$-i l b(o)$ & + & & \\
\hline$-u l b(o)$ & + & & \\
\hline$-t i v(o) / i v o$ & + & + & + \\
\hline$-\operatorname{tiva} / \boldsymbol{i v}(a)$ & + & & + \\
\hline -tário/ári(o) & + & & \\
\hline
\end{tabular}

Quadro II.24. Distribuição de sufixos formadores de nomes deverbais de indivíduo por tipos sintático-semânticos das bases

Pela análise do quadro, conclui-se que: 
a) os sufixos -nt(e), -dor, -dour(o), -ão, -deir(o), -deir(a), -óri(a)/ tóri(a) -eir $(o)$, -tiv(o)/ivo podem agregar-se a bases transitivas, inergativas e inacusativas;

b) os sufixos -dor(a), -vel, -alh(o), -alh(a), -elh(o), -ilh(a), -ilh(o), -ulh(o) e -tário/ári(o) apenas ocorrem em produtos com bases transitivas;

c) os sufixos -et(a),-dour(a), -al, -eir(a), -óri(o)/tóri(o) e -ão só selecionam bases transitivas e inergativas;

d) -tiva/iv(a) só foi registado com bases transitivas e inacusativas.

\subsubsection{Deverbais não sufixados}

Como se disse no início deste capítulo, os nomes deverbais podem ser formados sem o auxílio de afixos. Trata-se de nomes que na gramática tradicional são designados por "derivados regressivos" e cujo mecanismo de formação foi analisado em 1.6.3.

Nesta secção observaremos os tipos de semantismos gerados por este mecanismo, bem como as restrições de seleção das bases verbais.

Começa-se pelos nomes, como abraço, rogo, que resultam da conversão do radical verbal em radical nominal (2.4.3.1) e depois (2.4.3.2) descrevem-se os nomes que resultam da conversão de uma forma de palavra (ou palavra gramatical) (o siga, o pica).

\subsubsection{Deverbais que resultam da conversão do radical}

A conversão de radicais verbais em nominais ocorre a partir das 3 conjugações. Assim, existem deverbais conversos a partir de verbos de tema em -a- (abraçar > abraço), em -e-(morder > mordo) e em - $i$ - (curtir $>$ curte). Ao radical já converso anexa-se um marcador de classe $-a,-e$ ou $-o$. A relação entre o marcador de 
classe e o tema do verbo é aleatória, como se verifica no Quadro II.24. Verbos de tema em - $a$ - dão origem a deverbais com marcador de classe -a (malhar > malha), -e (ajustar > ajuste) e -o (regalar $>$ regalo). Verbos de tema em -e- também originam deverbais com marcador de classe $-a$ (colher $>$ colha), $-e$ (combater $>$ combate) e -o (sorver $>$ sorvo). Verbos de tema em - $i$ - apresentam deverbais com marcador de classe -a (zurzir > zurza), -e (curtir > curte) e -o (zumbir > zumbo).

\begin{tabular}{|l|l|l|l|}
\hline Deverbal & $\begin{array}{l}\text { marcador de } \\
\text { classe -a }\end{array}$ & $\begin{array}{l}\text { marcador de } \\
\text { classe -e }\end{array}$ & $\begin{array}{l}\text { marcador de } \\
\text { classe -o }\end{array}$ \\
\hline Verbo $1 .^{\text {a }}$ conj. & abraçar $>$ abraço & sacar $>$ saque & recuar $>$ recuo \\
\hline Verbo $2 .^{a}$ conj. & recolher $>$ recolha & combater $>$ combate & sorver $>$ sorvo \\
\hline Verbo $3 .^{\text {a }}$ conj. & zurzir $>$ zurza & curtir $>$ curte & cuspir $>$ cuspo \\
\hline
\end{tabular}

Quadro II.25. Relação entre marcador de classe de nomes conversos formados a partir de verbos das três conjugações e a VT destes

Uma vez que a vogal temática da base não se mantém no produto, a base verbal destes produtos é o radical.

As vogais finais dos deverbais têm a função de integrar o produto na categoria dos nomes. A mesma função ocorre nos marcadores de classe de nomes não derivados como roda, feixe, jato (cf. cap. 1: 1.2.2.2).

Verificam-se os seguintes tipos de estruturas morfológicas das bases: (i) bases simples não derivadas (miar>mio, jantar>janta, fungar>fungo, sacar>saque); (ii) bases complexas derivadas por prefixação (acamar>acama, alinhar>alinbo, afrontar>afronta; debagar>debaga, desabelhar $>$ desabelha, descamisar $>$ descamisa, encabeçar>encabeço, emperrar>emperro, enfaixar>enfaixa, esforçar>esforço, esgalhar $>$ esgalha, rebolar>rebolo, recuar $>$ recuo), por sufixação (baratear>barateio, coxear>coxeio, pestanejar>pestanejo, forcejar $>$ forcejo, saltarilhar $>$ saltarilho, lambiscar $>$ lambisco) 
e por circunfixação (aboquejar>aboquejo, acarrear>acarreio, espinotear>espinoteio); (iii) bases simples derivadas (conversos): balançar>balanço, enxofrar enxofra, galar>gala; (iv) bases complexas não derivadas (conversar>conversa, pernoitar>pernoita).

Estes deverbais não tomam por base verbos em -esc-, -ec-. Apenas se encontrou um deverbal converso a partir de um verbo em -iz- (vocalizo) e não se encontrou nenhum deverbal a partir de verbos em -ific-. Este mecanismo de formação de nomes prefere estruturas não eruditas.

Quanto aos tipos sintático-semânticos das bases verbais, estas são (i) bases transitivas, sobretudo causativas (podar, lavar) e de desempenho (escovar, escavar); (ii) bases inergativas de emissão de som (gritar, grasnar, roncar), emissão de substância (mijar, cuspir), emissão de luz (bruxulear, brilhar), modo de moção (coxear, rastejar). Não se encontram bases inacusativas.

A conversão de verbos em nomes requer que as bases possuam estruturas prosódicas particulares. Assim, este mecanismo exige que a base verbal tenha no radical pelo menos uma vogal que funcione como núcleo de sílaba, que será a sílaba acentuada. Assim, verbos como ver, dar, ler não produzem estes deverbais (Cf. Rodrigues 2004; Rodrigues 2009).

Os semantismos dos nomes conversos situam-se essencialmente em áreas tradicionais, como a agricultura, a pecuária, a pesca, ou em domínios domésticos de estrato familiar (Rodrigues 2004: 129-185). São os seguintes os semantismos dos nomes deverbais conversos:

(i) evento, dependendo da estrutura eventiva do verbo base (arremesso, começo, apara, degelo, tosquia). Muitos dizem respeito a tarefas agrícolas (lavra, malha, descamisa);

(ii) estado: sufoco, zanga, afogo, aconchego, amuo;

(iii) resultado concreto: aceno, abraço, afago, alinhavo, chapinho; 
(iv) instrumento não mecânico: abafo, abrigo, adorno, agasalbo, aguça, amarra, calça, espinça, estira 'ferramenta para descarnar couros', fisga, grateia 'instrumento para limpar o fundo dos rios', lixa, liga, mira, raspa, trincha; (v) agente humano: achego, bufo, desinço, esfervelho 'pessoa inquieta e travessa', pilho 'gatuno', visita;

(vi) causa genérica: amparo, atravanco, empeço, encanto;

(vii) locativo: abordo, abrigo, alojo, apoio, arrumo, assento, atalbo;

(viii) resíduos: alimpas 'resíduos dos cereais depois de serem joeirados', debulho 'resíduos dos cereais depois de debulhados', apara 'limalha', inço 'conjunto de plantas que não foram ceifadas, permanecem no terreno para futura propagação; restos'; (ix) objeto do evento: arranca 'pernada ou haste que se arrancou', caça, chucha, cria; (x) porção: ensancha 'porção de pano a mais para alargar posteriormente', estiva 'primeira porção de carga que se mete nos navios', aguante 'porção de velame que o navio pode aguentar';

(xi) vegetal: atrepa 'trepadeira', carrega 'planta';

(xii) instrumento mecânico: desdobro 'máquina própria para desdobrar';

(xiii) animal: saltarico 'gafanhoto';

(xiv) substância: empanque 'substância para vedar as juntas das máquinas'.

Quando uma base verbal apresenta significação eventiva abstrata e concreta, o deverbal converso apenas possui a significação de evento concreto (cf. Rodrigues 2009). Por exemplo, cria só é aplicável a entidades concretas: a cria de gado pelo João vs. *a cria de uma hipótese pelo João. Compare-se com o deverbal sufixado criação, em que as duas possibilidades são viáveis: a criação de gado pelo João vs. a criação de uma hipótese pelo João.

\subsubsection{Nomes deverbais conversos de forma de palavra}

Outra possibilidade de construir deverbais consiste na conversão de uma forma gramatical verbal em nome. Por exemplo, olhar $>$ 
olhar. No entanto, nem só do infinitivo se alimenta este formato da conversão. Atentemos nas seguintes formas, designadoras de 'indivíduo': atiça, barafusta, caça, cheira, chora, chupa, crava, rapa, espalha, endireita, pendura, engraxa, esfola, fura, grazina, guarda, guia, intruja, mirra, palra, pedincha, penetra, pica, rapa, rezinga, ronca, terlinta, tremelica, vigia, entre outras. Trata-se de formas ou masculinas ou de dois géneros, mantendo o formato da palavra (o intruja/a intruja).

Algumas destas formas de 'indivíduo' contrapõem-se aos corradicais de evento com base em contrastes de género. Por exemplo, o caça 'avião' vs. a caça 'evento de caçar', o barafusta 'aquele que barafusta' vs. a barafusta 'evento de barafustar'. Neste último caso, como nos demais que designam agente humano, a forma nominal é de dois géneros. Vejam-se exemplos como o/a crava, o/a endireita, o/a guarda, o/a guia, o/a pedincha, o/a penetra, o/a vigia, entre outras.

Todavia, o género feminino deste item (a barafusta: esta mulher é uma barafusta!) não se confunde com o item de género inerente que designa o evento (a barafusta durou muito tempo.).

Estas formas que designam 'indivíduos' resultam da conversão da palavra gramatical correspondente à $3 .^{a}$ pessoa do singular do presente do indicativo verbal em nome. A forma gramatical é convertida em nome. A colocação de determinante à esquerda da palavra assim o demonstra (O João barafusta muito/O barafusta acabou de chegar.)

As significações destes deverbais são de agente humano e de instrumento mecânico. No primeiro caso trata-se da focalização de um evento que passa a caraterizar um indivíduo/agente humano que o realiza com frequência. Este mecanismo é muito usado na construção de alcunhas, como em o siga: alcunha de um jovem delinquente contemporâneo.

Algumas destas palavras mantêm a relação com argumentos sem mediação de preposição, como no verbo derivante. É este o caso 
de o crava cigarros e de o pica bilhetes (cf. cap. 7: 7.3.2., para este tipo de compostos).

Atente-se na diferença em relação ao deverbal de evento, em que a mediação entre o deverbal e o seu argumento só ocorre através de preposição:

O Rui não acaba com a crava de cigarros.

* O Rui não acaba a crava cigarros.

Outras formas, que parecem mais estabelecidas no léxico, ocorrem já com mediação de preposição: O guarda do palácio vs. *o guarda palácio. No entanto, a forma com o argumento no plural é aceitável (o guarda palácios) e parece estar na origem de um composto. 